Prepared in cooperation with the

New Hampshire Department of Environmental Services and the U.S. Environmental Protection Agency, Region 1

\title{
Effects of a Remedial System and its Operation on Volatile Organic Compound-Contaminated Ground Water, Operable Unit 1, Savage Municipal Well Superfund Site, Milford, New Hampshire, 1998-2004
}

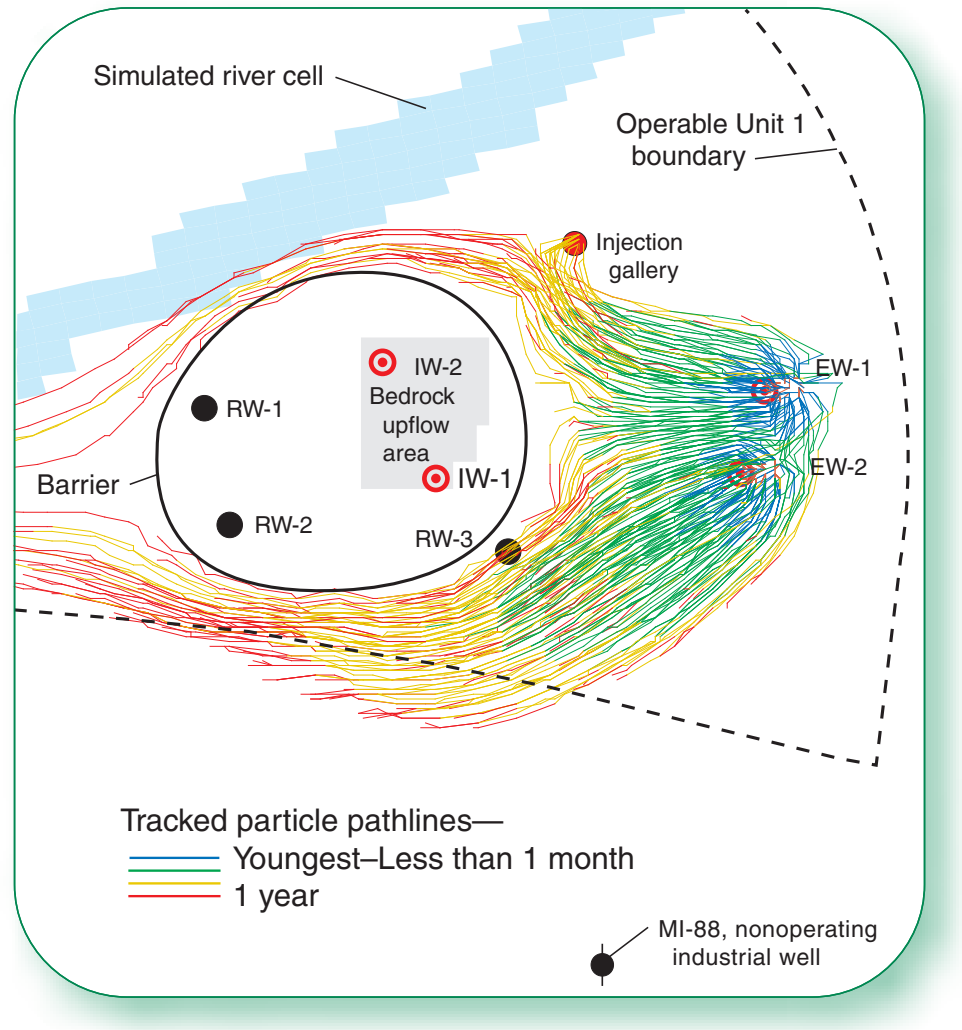

Scientific Investigations Report 2006-5083

U.S. Department of the Interior

U.S. Geological Survey 
Cover. Cover figure is an example of simulated backward-tracked particles showing capture areas to extraction wells EW-1 and EW-2 without withdrawals from well MI-88 near Operable Unit 1 in Milford, N.H. 


\section{Effects of a Remedial System and its Operation on Volatile Organic Compound- Contaminated Ground Water, Operable Unit 1, Savage Municipal Well Superfund Site, Milford, New Hampshire, 1998-2004}

By Philip T. Harte

Prepared in cooperation with the

New Hampshire Department of Environmental Services and the

U.S. Environmental Protection Agency, Region 1

Scientific Investigations Report 2006-5083 


\section{U.S. Department of the Interior DIRK KEMPTHORNE, Secretary \\ U.S. Geological Survey \\ P. Patrick Leahy, Acting Director}

\section{U.S. Geological Survey, Reston, Virginia: 2006}

For product and ordering information:

World Wide Web: http://www.usgs.gov/pubprod

Telephone: 1-888-ASK-USGS

For more information on the USGS--the Federal source for science about the Earth, its natural and living resources, natural hazards, and the environment:

World Wide Web: http://www.usgs.gov

Telephone: 1-888-ASK-USGS

Any use of trade, product, or firm names is for descriptive purposes only and does not imply endorsement by the U.S. Government.

Although this report is in the public domain, permission must be secured from the individual copyright owners to reproduce any copyrighted materials contained within this report.

Suggested citation:

Harte, P.T., 2006, Effects of a remedial system and its operation on volatile organic compound-contaminated ground water, Operable Unit 1, Savage Municipal Well Superfund site, Milford, New Hampshire, 1998-2004: U.S. Geological Survey Scientific Investigations Report 2006-5083, 80 p. 


\section{Contents}

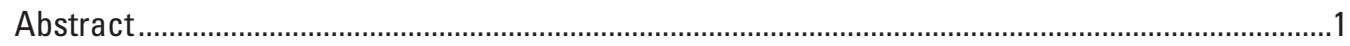

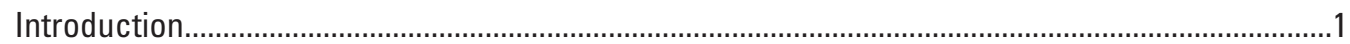

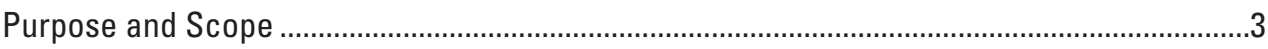

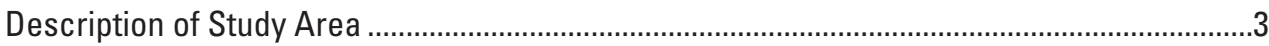

Overview of the Remedial System and its Operation ..........................................................

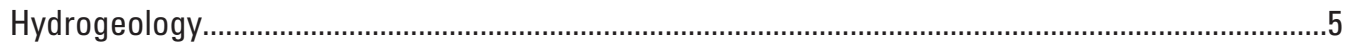

Previous Investigations of Contaminant Sources and Previous Remediation Efforts ......................8

Effects of the Remedial System and its Operation on Ground-Water Quality and Flow..................11

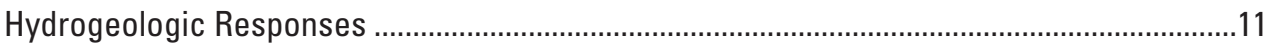

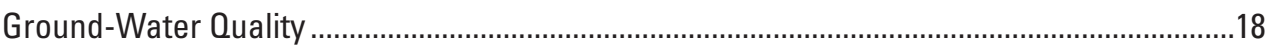

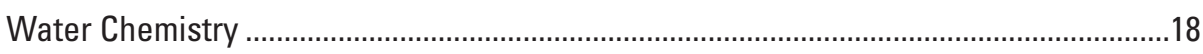

Volatile Organic Compound Trends ...........................................................................24

Effects of Barrier Construction and Trench Depths on Lateral Inflow....................................28

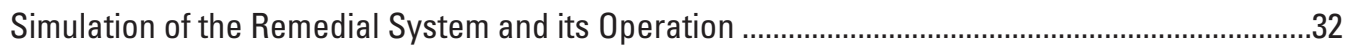

Effects of Operational Variations on Ground-Water Flow and Solute Transport.....................34

Sensitivity of Inside Barrier Area to Lateral Inflow...........................................................34

Sensitivity of Inside Barrier Area to Upflow from Bedrock ..............................................39

Sensitivity of Outside Barrier Area on Capture Zones to External Extraction Wells......41

Effects of Transient Flow on Capture Zones to Extraction Wells...........................................41

Alternative Operational Schemes to Accelerate Flushing of Contaminants ...........................44

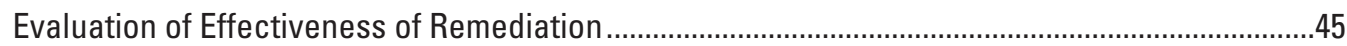

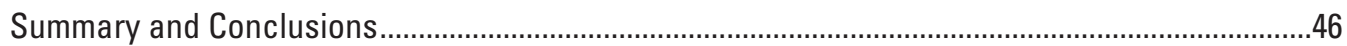

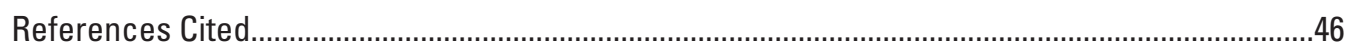

Appendixes 1-4

Appendix 1. Information on Wells and Vertical Profile Points, Savage Municipal Well

Superfund Site, Milford, N.H. ......................................................................................50

Appendix 2. Tetrachloroethylene Concentrations for Data Points Used in Figure 14, Operable Unit 1 (OU1), Savage Municipal Well Superfund Site, Milford, N.H....................65

Appendix 3. Information on Barrier-Trench Depths, Operable Unit 1 (OU1), Savage Municipal Well Superfund Site, Milford, N.H.

Appendix 4. Vertical Discretization for Model Row 91 of the Finite-Difference Grid, Savage Municipal Supply Well Superfund Site, Milford, N.H. 


\section{Figures}

1-2. Maps showing -

1. Location of the Milford-Souhegan Glacial-Drift (MSGD) aquifer, Savage well, and Operable Units 1 (OU1) and 2 (OU2) of the Savage Municipal Well

Superfund site, Milford, N.H.

2. Operable Unit 1 (OU1) remedial system, PCE concentration in ground water (1995), and wells, Savage Municipal Well Superfund site, Milford, N.H. . .4

3. Cross section $A-A^{\prime}$ through Operable Unit 1 (OU1) showing $A$, natural gamma log results, $B$, lithology, and $C$, interpretation of stratigraphy, Milford, N.H. .9

4-6. Maps showing-

4. Potentiometric-head contours of middle overburden after barrier construction but under non-operating conditions during low recharge, January 2002, Operable Unit 1 (OU1), Milford, N.H.

5. Water-table and potentiometric-head contours for $A$, shallow, $B$, medium, and $C$, deep overburden under operating conditions during low recharge, November 2001, Operable Unit 1 (OU1), Milford, N.H.

6. Potentiometric-head contours of middle overburden in a high recharge period under $A$, operations in May 2002, and $B$, partial operating conditions in April 2004, Operable Unit 1 (OU1), Milford, N.H.

7. Graph showing water-level drawdowns from interior extraction at continuously monitored observation wells, Operable Unit 1 (OU1), Milford, N.H...

8. Schematic diagrams of ground-water flow patterns between the overburden and bedrock inside and outside the barrier area for $A$, non-operating extraction conditions, and $B$, operating conditions, Operable Unit 1 (OU1), Milford, N.H.

9. Graphs showing specific conductance for selected observation-well clusters in Operable Unit 1 (OU1), Milford, N.H. $A$, shallow (S) overburden wells; $B$, middle (M) overburden wells and B95-3; and $C$, deep (D) overburden and bedrock (R) wells. .......21

10-11. Trilinear diagrams:

10. Major anion and cation chemistry for remedial wells (2004) and shallow overburden wells (1998), Operable Unit 1 (OU1), Milford, N.H.

11. Major anion and cation chemistry for deep overburden wells and bedrock samples (1998), Operable Unit 1 (OU1), Milford, N.H.

12-14. Maps showing-

12. Concentrations of tetrachloroethylene (PCE) in middle overburden, December 1998, Operable Unit 1 (OU1), Milford, N.H.

13. Concentrations of tetrachloroethylene (PCE) in middle overburden, November 2001, Operable Unit 1 (OU1), Milford, N.H.....

14. Maximum concentrations of tetrachloroethylene (PCE) in November 2001 for $A$, shallow, $B$, middle, and $C$, deep overburden, Operable Unit 1 (OU1), Milford, N.H.

15-16. Graphs showing-

15. Concentrations of $A$, tetrachloroethylene (PCE), $B$, trichloroethylene (TCE), and $C$, cis-1,2 dichloroethylene (cis-DCE) for PW-12 cluster wells, Operable Unit 1 (OU1), Milford, N.H., 1998-2004.

16. Concentrations of $A$, tetrachloroethylene (PCE), $B$, trichloroethylene (TCE), and $C$, cis-1,2 dichloroethylene (cis-DCE) for PW-6 cluster wells, Operable Unit (OU1), Milford, N.H., 1998-2004. 
17-23. Maps showing-

17. Location, reference lines, and station numbers for completed (as built) barrier-trench system, Operable Unit 1 (OU1), Milford, N.H.

18. Model-computed head contours in layer 4 for remedial-operation rates in $A, 1999, B, 2001$, and $C, 2002$, Operable Unit 1 (OU1), Milford, N.H.

19. Model-computed horizontal ground-water velocity vectors for velocities above 0.84 feet per day for $A, 1999, B, 2001$, and $C, 2002$, Operable Unit 1 (OU1), Milford, N.H.

20. Backward-tracked particles showing capture areas to IW-1 and IW-2 in $A$, 1999, B, 2001, and C, 2002, Operable Unit 1 (OU1), Milford, N.H.

21. Backward-tracked particles showing capture areas to IW-1 and IW-2 with no horizontal inflow under the barrier in layer 5, 2002 rates, Operable Unit 1 (OU1), Milford, N.H.

22. Backward-tracked particles showing capture areas to EW-1 and EW-2 in $A, 1999, B, 2001$, and C, 2002, Operable Unit 1 (OU1), Milford, N.H.

23. Backward-tracked particles showing capture areas to EW-1 and EW-2 for 2002 rates $A$, with, and $B$, without withdrawals from MI-88, Operable Unit 1 (OU1), Milford, N.H.

\section{Tables}

1. Location, well screen data, and geology for selected wells in Operable Unit 1 (OU1), Savage Municipal Well Superfund site, Milford, N.H.

2. Summary of inorganic and selected volatile organic compounds, Operable Unit 1 (OU1), Savage Municipal Well Superfund site, Milford, N.H.

3. Observed PCE concentrations of exterior barrier wells for December 1998, May 2000, November 2001, and April 2004 in Operable Unit 1 (OU1), Savage Municipal Well Superfund site, Milford, N.H.

4. Observed PCE concentrations of interior barrier wells for December 1998, May 2000, November 2001, and April 2004 in Operable Unit 1 (OU1), Savage Municipal Well Superfund site, Milford, N.H.

5. Remedial wells and operational rates for selected wells 1999-2003, Operable Unit 1 (OU1), Savage Municipal Well Superfund site, Milford, N.H.

6. Model ground-water budget terms evaluated during simulations of interior barrier area remedial system, Operable Unit 1 (OU1), Savage Municipal Well Superfund site, Milford, N.H.

7. Advective transport and capture of a line-source of ground-water particles from steady state and transient models, Operable Unit 1 (OU1), Savage Municipal Well Superfund site, Milford, N.H.

8. Simulations testing alternative injection locations outside the barrier wall for Operable Unit 1 (OU1), Savage Municipal Well Superfund site, Milford, N.H 


\section{Conversion Factors and Datums}

\begin{tabular}{|c|c|c|}
\hline Multiply & By & To obtain \\
\hline \multicolumn{3}{|c|}{ Length } \\
\hline inch (in.) & 2.54 & centimeter $(\mathrm{cm})$ \\
\hline inch (in.) & 25.4 & millimeter $(\mathrm{mm})$ \\
\hline foot $(\mathrm{ft})$ & 0.3048 & meter $(\mathrm{m})$ \\
\hline mile (mi) & 1.609 & kilometer $(\mathrm{km})$ \\
\hline \multicolumn{3}{|c|}{ Area } \\
\hline square foot $\left(\mathrm{ft}^{2}\right)$ & 929.0 & square centimeter $\left(\mathrm{cm}^{2}\right)$ \\
\hline square foot $\left(\mathrm{ft}^{2}\right)$ & 0.09290 & square meter $\left(\mathrm{m}^{2}\right)$ \\
\hline square inch $\left(\mathrm{in}^{2}\right)$ & 6.452 & square centimeter $\left(\mathrm{cm}^{2}\right)$ \\
\hline square mile $\left(\mathrm{mi}^{2}\right)$ & 259.0 & hectare (ha) \\
\hline square mile $\left(\mathrm{mi}^{2}\right)$ & 2.590 & square kilometer $\left(\mathrm{km}^{2}\right)$ \\
\hline \multicolumn{3}{|c|}{ Volume } \\
\hline gallon (gal) & 3.785 & liter (L) \\
\hline gallon (gal) & 0.003785 & cubic meter $\left(\mathrm{m}^{3}\right)$ \\
\hline gallon (gal) & 3.785 & cubic decimeter $\left(\mathrm{dm}^{3}\right)$ \\
\hline million gallons (Mgal) & 3,785 & cubic meter $\left(\mathrm{m}^{3}\right)$ \\
\hline cubic foot $\left(\mathrm{ft}^{3}\right)$ & 28.32 & cubic decimeter $\left(\mathrm{dm}^{3}\right)$ \\
\hline cubic foot $\left(\mathrm{ft}^{3}\right)$ & 0.02832 & cubic meter $\left(\mathrm{m}^{3}\right)$ \\
\hline \multicolumn{3}{|c|}{ Flow rate } \\
\hline foot per second (ft/s) & 0.3048 & meter per second $(\mathrm{m} / \mathrm{s})$ \\
\hline foot per day (ft/d) & 0.3048 & meter per day $(\mathrm{m} / \mathrm{d})$ \\
\hline foot per year (ft/yr) & 0.3048 & meter per year (m/yr) \\
\hline cubic foot per second $\left(\mathrm{ft}^{3} / \mathrm{s}\right)$ & 0.02832 & cubic meter per second $\left(\mathrm{m}^{3} / \mathrm{s}\right)$ \\
\hline cubic foot per day $\left(\mathrm{ft}^{3} / \mathrm{d}\right)$ & 0.02832 & cubic meter per day $\left(\mathrm{m}^{3} / \mathrm{d}\right)$ \\
\hline gallon per minute (gal/min) & 0.06309 & liter per second (L/s) \\
\hline gallon per day (gal/d) & 0.003785 & cubic meter per day $\left(\mathrm{m}^{3} / \mathrm{d}\right)$ \\
\hline million gallons per day (Mgal/d) & 0.04381 & cubic meter per second $\left(\mathrm{m}^{3} / \mathrm{s}\right)$ \\
\hline inch per year (in/yr) & 25.4 & millimeter per year $(\mathrm{mm} / \mathrm{yr})$ \\
\hline \multicolumn{3}{|c|}{ Pressure } \\
\hline pound per square inch $\left(\mathrm{lb} / \mathrm{in}^{2}\right)$ & 6.895 & kilopascal $(\mathrm{kPa})$ \\
\hline \multicolumn{3}{|c|}{ Specific capacity } \\
\hline gallon per minute per foot $[(\mathrm{gal} / \mathrm{min}) / \mathrm{ft})]$ & 0.2070 & liter per second per meter $[(\mathrm{L} / \mathrm{s}) / \mathrm{m}]$ \\
\hline \multicolumn{3}{|c|}{ Hydraulic conductivity } \\
\hline foot per day $(\mathrm{ft} / \mathrm{d})$ & 0.3048 & meter per day $(\mathrm{m} / \mathrm{d})$ \\
\hline \multicolumn{3}{|c|}{ Hydraulic gradient } \\
\hline foot per foot $(\mathrm{ft} / \mathrm{ft})$ & 0.3048 & meter per meter $(\mathrm{m} / \mathrm{m})$ \\
\hline foot per mile (ft/mi) & 0.1894 & meter per kilometer $(\mathrm{m} / \mathrm{km})$ \\
\hline \multicolumn{3}{|c|}{ Transmissivity* } \\
\hline foot squared per day $\left(\mathrm{ft}^{2} / \mathrm{d}\right)$ & 0.09290 & meter squared per day $\left(\mathrm{m}^{2} / \mathrm{d}\right)$ \\
\hline
\end{tabular}


Temperature in degrees Celsius $\left({ }^{\circ} \mathrm{C}\right)$ may be converted to degrees Fahrenheit $\left({ }^{\circ} \mathrm{F}\right)$ as follows:

$$
{ }^{\circ} \mathrm{F}=\left(1.8 \times^{\circ} \mathrm{C}\right)+32
$$

Temperature in degrees Fahrenheit $\left({ }^{\circ} \mathrm{F}\right)$ may be converted to degrees Celsius $\left({ }^{\circ} \mathrm{C}\right)$ as follows:

$$
{ }^{\circ} \mathrm{C}=\left({ }^{\circ} \mathrm{F}-32\right) / 1.8
$$

Vertical coordinate information is referenced to the National Geodetic Vertical Datum of 1929 (NGVD 29).

Horizontal coordinate information is referenced to the North American Datum of 1983 (NAD 83).

Altitude, as used in this report, refers to distance above the vertical datum.

*Transmissivity: The standard unit for transmissivity is cubic foot per day per square foot times foot of aquifer thickness $\left[\left(\mathrm{ft}^{3} / \mathrm{d}\right) / \mathrm{ft}^{2}\right] \mathrm{ft}$. In this report, the mathematically reduced form, foot squared per day $\left(\mathrm{ft}^{2} / \mathrm{d}\right)$, is used for convenience.

Specific conductance is given in microsiemens per centimeter at 25 degrees Celsius $(\mu \mathrm{S} / \mathrm{cm}$ at $\left.25^{\circ} \mathrm{C}\right)$.

Concentrations of chemical constituents in water are given either in milligrams per liter ( $\mathrm{mg} / \mathrm{L}$ ), approximately equivalent to parts per million $(\mathrm{ppm})$, or micrograms per liter $(\mu \mathrm{g} / \mathrm{L})$, approximately equivalent to parts per billion (ppb).

\section{ABBREVIATIONS AND EXPLANATIONS OF TERMS USED IN THIS REPORT:}

$\begin{array}{ll}\text { cis-1,2-DCE } & \text { cis-1,2-dichloroethene } \\ \text { DCE } & \text { dichloroethene } \\ \text { DNAPL } & \text { Dense Non-Aqueous Phase Liquid } \\ \text { MSGD } & \text { Milford-Souhegan Glacial-Drift aquifer } \\ \text { OU1 } & \text { Operable Unit } 1 \text { of the Savage Municipal Well Superfund site } \\ \text { OU2 } & \text { Operable Unit } 2 \text { of the Savage Municipal Well Superfund site } \\ \text { PCE } & \text { tetrachloroethylene } \\ \text { TCE } & \text { trichloroethylene } \\ \text { TOC } & \text { total organic carbon } \\ \text { VOC } & \text { volatile organic compound }\end{array}$

UNITS OF MEASUREMENT

g grams

$\min \quad$ minute

yr year 


\section{WELL IDENTIFICATION, ABBREVIATIONS, AND EXPLANATION}

Well names used in this report, including appendix 1, are typically designated based on previous studies. In some cases, well names are designated after the owner's name.

Prefix for remedial wells

EW

IW

RW

SP

SVE

Miscellaneous

VP

INEEL exterior barrier wall extraction well

interior barrier wall extraction well

recharge wells

air sparge well (used for remedial technology that reduces concentrations of volatile contaminants adsorbed to soils and dissolved in ground water in the saturated zone; involves the injection of air into the saturated zone)

soil vapor extraction well (used for remedial technology that reduces concentrations of volatile contaminants adsorbed to soils in the unsaturated zone; involves the extraction of air from the unsaturated zone)

vertical profile

well located in INEEL well field (Idaho National Engineering and Environmental Laboratory)

\section{Prefix for observation wells}

$\mathrm{P}$

piezometer

$\mathrm{PW}, \mathrm{B}, \mathrm{MI}$, and MW observation wells

Suffix for observation wells

D or C deep cluster well; typically set at depths greater than 70.1 feet below land surface

M or B medium cluster well; typically set at depths between 40.1 and 70.1 feet below land surface

$\mathrm{R} \quad$ bedrock well

S or A shallow cluster well; typically set at depths less than 40.1 feet below land surface

Lithology abbreviations

C

coarse

f fine

m medium

Wx weathered 


\section{Acknowledgments}

This study was conducted as part of the remedial effort of the Savage Municipal Well Superfund site and is a collaborative effort between Federal, State, and local governments, and private companies and individuals. The author wishes to thank Thomas Andrews of the New Hampshire Department of Environmental Services (NHDES); Richard Goehlert, site remedial project manager of the U.S. Environmental Protection Agency (USEPA), Region 1; and Richard Willey, lead hydrogeologist, USEPA, Region 1, for their cooperation and support. 



\title{
Effects of a Remedial System and its Operation on Volatile Organic Compound-Contaminated Ground Water, Operable Unit 1, Savage Municipal Well Superfund Site, Milford, New Hampshire, 1998-2004
}

\author{
By Philip T. Harte
}

\section{Abstract}

The Savage Municipal Well Superfund site in the Town of Milford, N.H., is underlain by a 0.5-square mile plume of volatile organic compounds (VOCs), mostly tetrachloroethylene (PCE). The plume occurs mostly within a highly transmissive sand and gravel layer, but also extends into underlying till and bedrock. The plume has been divided into two areas called Operable Unit 1 (OU1), which contains the primary source area, and Operable Unit 2 (OU2), which is defined as the extended plume area.

PCE concentrations in excess of 100,000 parts per billion (ppb) had been detected in the OU1 area in 1995, indicating a likely Dense Non-Aqueous Phase Liquid (DNAPL) source. In the fall of 1998, the New Hampshire Department of Environmental Services (NHDES) and the U.S. Environmental Protection Agency (USEPA) installed a remedial system in OU1 to contain and capture the dissolved VOC plume. The OU1 remedial system includes a low-permeability barrier wall that encircles the highest detected concentrations of PCE, and a series of injection and extraction wells to contain and remove contaminants. The barrier wall likely penetrates the full thickness of the sand and gravel; in most places, it also penetrates the full thickness of the underlying basal till and sits atop bedrock. Remedial injection and extraction wells have been operating since the spring of 1999 and include a series of interior (inside the barrier wall) injection and extractions wells and exterior (outside the barrier wall) injection and extraction wells. A recharge gallery outside the barrier wall receives the bulk of the treated water and reinjects it into the shallow aquifer.

From 1998 to 2004, PCE concentrations decreased by an average of 80 percent at most wells outside the barrier wall. This decrease indicates (1) the barrier wall and interior extraction effectively contained high PCE concentrations inside the wall, (2) other sources of PCE did not appear to be outside of the wall, and (3) ambient ground-water flow in conjunction with the exterior remedial wells effectively remediated most of the dissolved PCE plume outside the wall.
The overburden at middle depths (40 to $70 \mathrm{ft}$ below land surface) downgradient from exterior extraction wells showed relatively slow decreases in PCE concentrations compared to other areas outside the barrier wall. Numerical simulation shows extraction caused the formation of a small downgradient slow-velocity zone. Because the ambient ground-water velocities are high (approximately 1 foot per day), temporary termination of extraction at the exterior wells may increase dilution downgradient from the exterior extraction wells. Extraction can also be optimized on the basis of seasonal hydrologic conditions to facilitate exterior well capture from upgradient areas outside of the barrier wall where PCE concentrations are highest.

Reductions in concentrations of PCE inside the barrier wall from 1998 to 2003 were minimal near suspected source areas, indicating that the operation of interior remedial wells had not been effective in remediating dissolved PCE or the DNAPL source. Capture of the dissolved PCE plume within the barrier wall by interior extraction wells could be enhanced if operation (injection rates) increased at underutilized interior injection wells, thereby increasing hydraulic gradients.

\section{Introduction}

The Savage Municipal Well Superfund site (Savage site), named after a former municipal water-supply well (the Savage well) for the Town of Milford, N.H., is underlain by a $0.5-\mathrm{mi}^{2}$ plume of volatile organic compounds (VOCs), consisting primarily of tetrachloroethylene (PCE) (fig. 1). The VOC plume occurs mostly within a highly transmissive sand and gravel layer but also extends to underlying till and bedrock. The sand and gravel layer, part of the Milford-Souhegan-GlacialDrift aquifer (MSGD), is an important source of water for a New Hampshire State Fish Hatchery, which uses more than $2 \mathrm{Mgal} / \mathrm{d}$. Before contamination with VOCs, the aquifer also supplied more than $1 \mathrm{Mgal} / \mathrm{d}$ to two municipal water-supply wells (the Savage well and a well outside of the study area). 


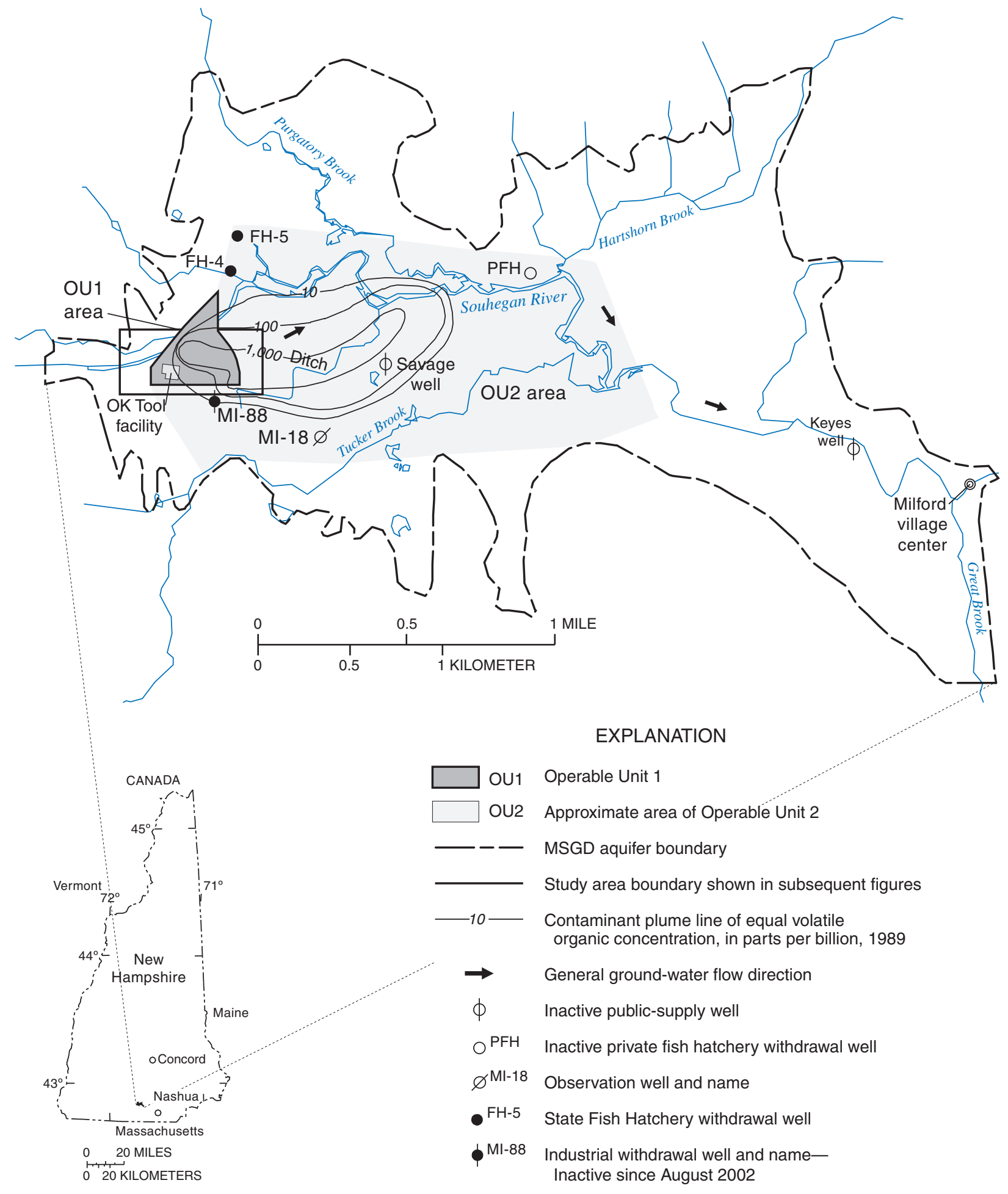

Figure 1. Location of the Milford-Souhegan Glacial-Drift (MSGD) aquifer, Savage well, and Operable Units 1 (OU1) and 2 (OU2) of the Savage Municipal Well Superfund site, Milford, N.H. 
A discontinued tool manufacturing facility, the OK Tool facility, in Operable Unit 1 (OU1), has been identified as the primary source (HMM Associates, Inc., 1989 and 1991) of PCE that led to the contamination of the Savage well. The contaminant plume downgradient from OU1 is designated Operable Unit (OU2), also called the extended plume area.

The State of New Hampshire Department of Environmental Services (NHDES) and the U.S. Environmental Protection Agency (USEPA) Region 1 have constructed a remedial system for the OU1 area (fig. 2). The remedial system consists of a low-permeability barrier wall, which surrounds the highest concentrations of dissolved PCE and most likely some Dense Non-Aqueous Phase Liquid (DNAPL), and includes various injection and extraction wells (vapor and water) to capture and treat the dissolved contaminant plume. The barrier wall was constructed from July to November 1998. Remedial operations of wells were tested from December 1998 to March 1999, and full operation started in May 1999.

The U.S. Geological Survey (USGS), in cooperation with the NHDES and the USEPA, Region 1, is studying the solute transport of VOCs (primarily PCE) in contaminated ground waters of the unconsolidated sediments (overburden) of the Savage site. Specific objectives of the cooperative study include the following:

1. Evaluate effectiveness of remedial operations in the OU1 area,

2. Help improve long-term (more than 1 year) forecasting of PCE decreases in the overburden on the basis of current (1999-2004) remedial operations,

3. Identify important processes that affect contaminant transport, and

4. Improve upon long-term (more than 1 year) monitoring strategies by helping to design a cost-effective monitoring network.

Previous studies by the USGS of the study site include construction and calibration of two ground-water-flow models (Harte and others, 1999; Harte and Mack, 1992), evaluation of effects of ground-water withdrawals on advective transport of contaminated ground waters (Harte and Willey, 1997), analysis of PCE trends for pre- and post-barrier conditions (Harte and others, 2001), and description of results of a monitoring program of continuous water levels from water years 1997-2003 (Brayton and Harte, 2001; Harte, 2005). Furthermore, solute transport of PCE was investigated and a transport model calibrated for the OU1 and OU2 areas (Harte, 2004).

\section{Purpose and Scope}

This report describes the remedial system of OU1 and includes an evaluation of the effectiveness of the remedial system from 1998 to 2004 in terms of efficient capture of VOCs and reduction of their concentrations. Included in the evaluation is an integration of hydrologic, geophysical, and chemical data. Simulations of ground-water flow and transport of PCE were performed to assist in the evaluation process. Possible options to enhance remedial effectiveness are also discussed.

\section{Description of Study Area}

The MSGD aquifer is defined as the entire sequence of unconsolidated sediments (overburden) overlying the bedrock in the Souhegan River Valley of Milford, N.H. This section of the report includes a description of the MSGD aquifer area, which includes the river valley shown in figure 1, and of the OU1 area that is in the western part of the MSGD aquifer.

The river valley slopes gently to the east at approximately $12 \mathrm{ft} / \mathrm{mi}$ along the Souhegan River. Land-surface elevations range from 230 to $280 \mathrm{ft}$ in the valley and water drains to the Souhegan River and its tributaries (fig. 1), including Tucker, Purgatory, Great, and Hartshorn Brooks, and a number of small, unnamed streams. A discharge ditch drains processed waters from a manufacturing company in the southwestern part of the study area. Discharge to the ditch was reduced in August 2002.

Land use in the MSGD aquifer area is predominantly industrial in the southwestern part, agricultural in the central and northwestern parts, and residential and commercial elsewhere. The contaminant plume (fig. 2) underlies a large agricultural area in the center of the plume (not shown on any figures) and abuts a commercial-industrial area to the south.

Ground-water withdrawals in 2001 were primarily used for commercial and industrial purposes. Withdrawal wells include two wells for the State Fish Hatchery in the northwestern part of the study area (wells FH-4 and FH-5, fig. 1) that withdraw more than $2 \mathrm{Mgal} / \mathrm{d}$. Consumptive use is small because most of the withdrawn water is returned to Purgatory Brook (fig. 1). A discontinued withdrawal well at a private fish hatchery (PFH, fig. 1) in the eastern part of the study area withdrew $0.14 \mathrm{Mgal} / \mathrm{d}$ until the late 1990s. A discontinued (as of August 2002) withdrawal well (MI-88, fig. 1) at an industrial complex in the southwestern part of the study area withdrew about $0.25 \mathrm{Mgal} / \mathrm{d}$ as reported in 1995 . The effluent from this well was formerly discharged to the aforementioned drainage ditch.

The former OK Tool facility in OU1 had been identified as the primary source of VOCs to the Savage well (HMM Associates, Inc., 1989, 1991) and is in the western part of the MSGD aquifer (figs. 1 and 2). Solvents were discharged into the subsurface at this facility for many years until the early 1980s. Although discharges have ceased, the underlying contaminant-soaked sediments and immiscible solvents (most likely DNAPLs) continued to contaminate ground water flowing easterly underneath the site until a barrier wall was constructed in 1998.

The barrier wall (referred to as "barrier" in this report) is constructed of low-permeability materials (bentonite clay) and is designed to contain the highest concentrations of contaminants. The barrier encircles a $0.008-\mathrm{mi}^{2}$ area and generally 


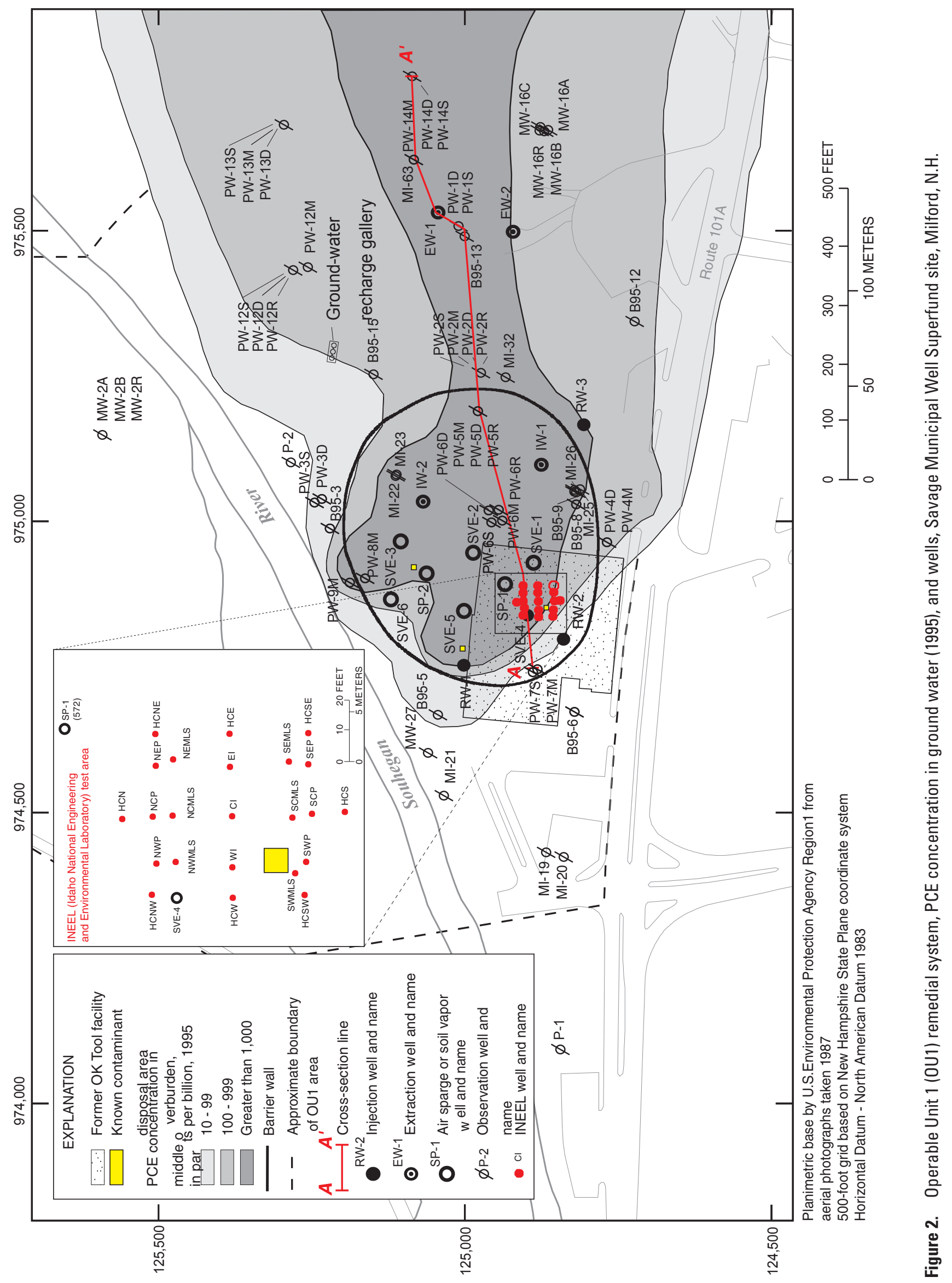


fully penetrates the overburden (sand and gravel layers and underlying till); it sits atop the bedrock in most cases. The barrier was designed to at least penetrate $3 \mathrm{ft}$ into the basal till but in many locations this minimum depth was exceeded. In the eastern part of the barrier, till thickness is less than $3 \mathrm{ft}$ and the barrier sits atop bedrock. Various injection and extraction wells (fig. 2, appendix 1) were installed within and outside the barrier to insure hydraulic isolation, reduce contaminant mass inside the barrier wall, and to capture and treat contaminants outside the barrier.

Maximum concentrations of PCE, the primary contaminant, ranged from $100,000 \mathrm{ppb}$ inside the wall to $10,000 \mathrm{ppb}$ outside the wall in 1995 (Camp, Dresser, and McKee, Inc., Federal Programs Corporation, 1995). Secondary VOCs (TCE and cis-1,2-DCE) concentrations were typically one to two orders of magnitude less than those of PCE (Harte and others, 2001).

\section{Overview of the Remedial System and its Operation}

The remedial extraction wells in OU1 help capture VOCcontaminated (primarily PCE) ground water, which is then piped to an onsite treatment plant for decontamination and injection back into the aquifer. Extraction wells include soil vapor extraction (SVE) wells and water wells. SVE wells are inside the barrier and are used to remediate the VOC plume by extracting volatilized VOC from the vadose zone. SVE wells have been sporadically used from 1998 to 2004. Ground-water extraction wells inside the barrier include wells IW-1 and IW-2 (fig. 2). These wells capture PCE and maintain inward hydraulic gradients, which reduce outflow of PCE from within the barrier area. Two ground-water extraction wells (EW-1 and EW-2, fig. 2, table 1) outside and downgradient from the barrier are used to capture PCE outside the barrier. Injection wells include two wells inside of the barrier on the upgradient end (RW-1 and RW-2, fig. 2). These wells are used to prevent inflow of uncontaminated waters from outside the barrier and to induce hydraulic gradients within the barrier. Another injection well (RW-3, fig. 2) is outside of, and downgradient from, the barrier. A recharge gallery outside the barrier on the northern flank of the plume (fig. 2) receives most of the treated water and injects water into the shallow (less than $20 \mathrm{ft}$ ) subsurface. Air sparging (SP) wells (SP-1 and SP-2, fig. 2) inside the barrier are used to inject air into the deep overburden to facilitate transfer of VOCs that are adhered onto soils into the vapor phase. SP wells were primarily inactive from 1998 to 2004.

From 1999 to 2003, the net amount of water extracted (extraction minus injection) inside the barrier was increased in an attempt to decrease heads inside the barrier to maintain inward hydraulic gradients around the barrier and allow the efficient use of the soil vapor extraction (SVE) wells. SVE wells work most efficiently when water levels inside the barrier are less than $255 \mathrm{ft}$. Continuously monitored water levels from well B95-9 inside the barrier (fig. 2, table 1) showed that water levels generally did not decrease below $257 \mathrm{ft}$ (Harte, 2005) although the net extraction inside the barrier increased by a factor of six from 1999 to 2003 .

\section{Hydrogeology}

The MSGD aquifer (fig. 1) is defined as the entire sequence of unsaturated and saturated alluvium, glacial drift, and other unconsolidated deposits overlying the bedrock surface in the Souhegan River Valley in Milford. The aquifer consists primarily of stratified sand and gravel with some basal till, and is overlain in places by recent alluvium. The maximum saturated thickness of the aquifer exceeds $80 \mathrm{ft}$, but generally ranges from 0 to $60 \mathrm{ft}$. The aquifer is bounded laterally by till-covered bedrock uplands.

Two bedrock types underlying the aquifer have been identified in rock cores. These types include a white to pink, medium to coarse-grained granite, and a gray biotite-rich diorite gneiss (HMM Associates, Inc., 1989, 1991). Lyons and others (1997) identified several bedrock units in the Milford area including the Massabesic Gneiss Complex of Late Proterozoic age, an unnamed intrusive gray biotite granite of Permian age, and biotite quartz diorite of early Devonian age (Spaulding Tonalite). A high-angle strike-slip fault called the Campbell Hill Fault traverses the study area in a southwestnortheast trend. The degree of fracturing of the bedrock is unknown, but wells set in bedrock yield water. Because the primary porosity of the underlying bedrock in the study area is negligible, fractures are the principal mechanism to transmit ground-water flow.

Till forms the basal unit of unconsolidated sediments and discontinuously overlies bedrock (Harte and Mack, 1992). The till has a sandy to silty matrix and can contain pebbles, cobbles, and boulders. The till is thickest (greater than $20 \mathrm{ft}$ thick) in the westernmost part of the valley.

Stratified-drift deposits represent the most transmissive units underlying the site. Estimates of hydraulic conductivity exceed $100 \mathrm{ft} / \mathrm{d}$ (Camp, Dresser, and McKee, Inc., 1996) in the gravel and sand layers of the stratified-drift deposits. Stratified drift was deposited in ice-contact, fluvial deltas, and outwash environments (Koteff, 1970). During the late stages of Pleistocene glaciation, a west-to-east drainage pattern that was similar to present drainage patterns caused coarser sediments to be deposited in the western part of the valley. Specifically, glacial drainage occurred through the channel occupied by Purgatory Brook (fig. 1) and through the channel occupied by the Souhegan River west of OU1. These glacial-drainage channels transported coarse-grained sediments into the present-day Souhegan River Valley.

The unconsolidated sediments beneath the Savage site consist of up to 100-ft-thick deposits of predominantly sand and gravel. In OU1, lithologic logs show that sand and gravel sequences are interspersed with discontinuous finer grained 


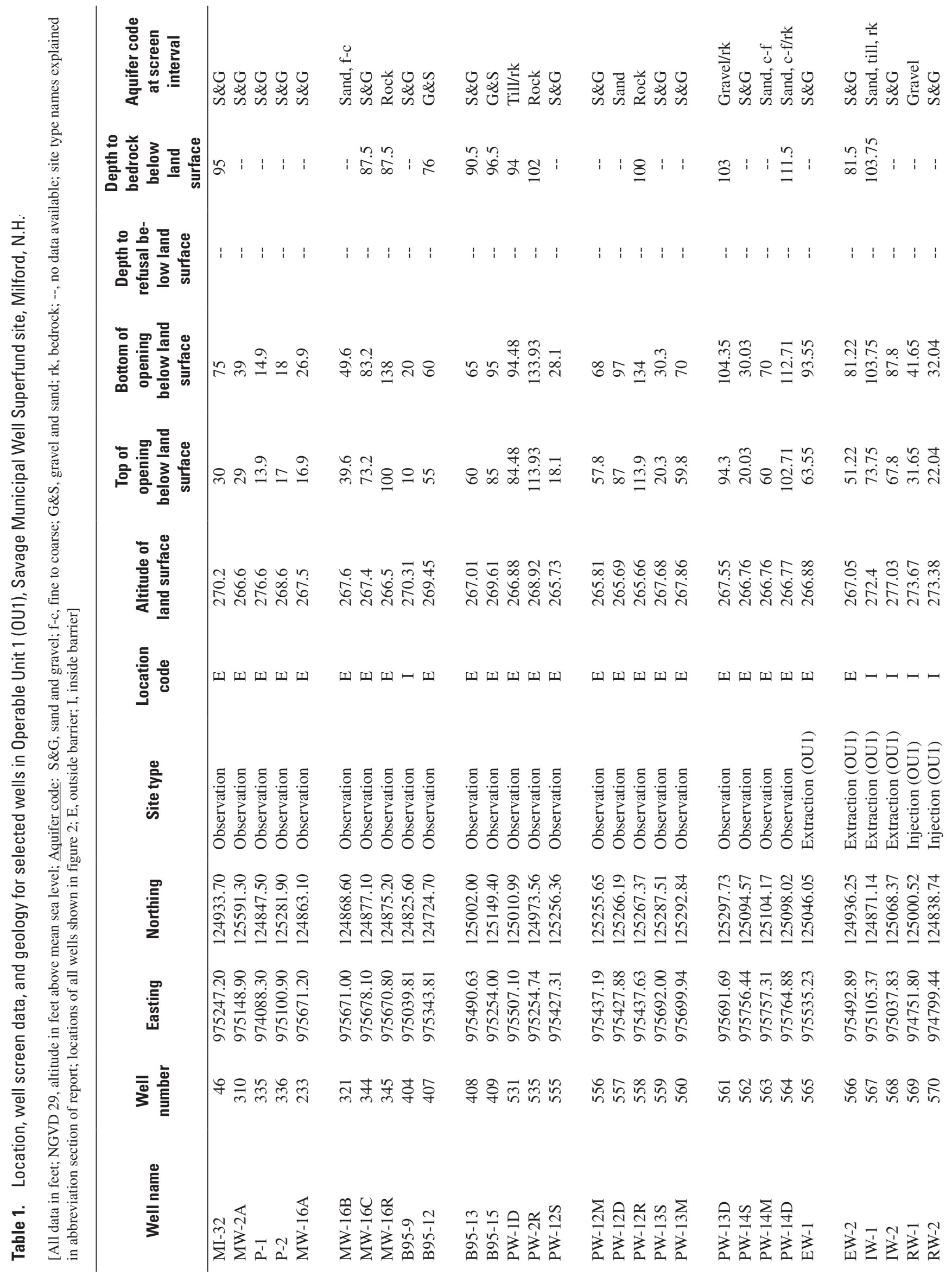




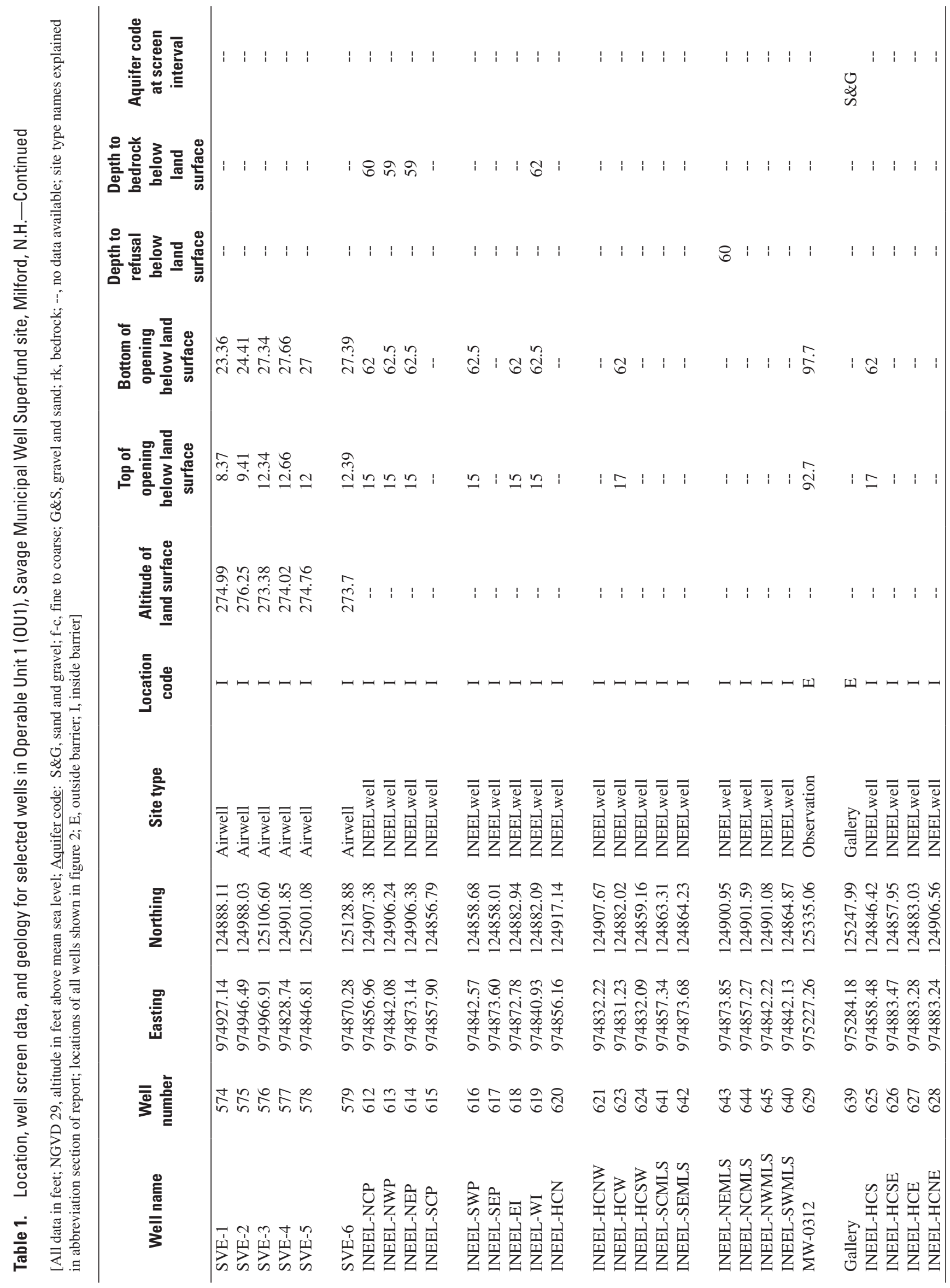


sands at depths of 40 and $70 \mathrm{ft}$. Coarse-grained deposits (cobbles and gravels) occur at the uppermost layer near the water table (at a depth of 6-18 ft), at around $60 \mathrm{ft}$, and near the base of the unconsolidated sediments at $90 \mathrm{ft}$.

The stratigraphy of the study area was apparently created by a sequence of multiple glacial advances. The deep, coarsegrained deposits at $85-90 \mathrm{ft}$ below land surface indicate that subglacial meltwater eroded deeply into the potentially weakened bedrock near the Campbell Hill Fault Zone. According to Randall (2001), many subglacial channels persisted throughout later stages of deglaciation and deposited sand and gravel atop bedrock near the retreating ice margin. The remaining deposits in OU1 indicate meltwater deposition in the form of deltas, outwash, and a glacial outburst deposit, which deposited a coarse cobble zone near the uppermost sequence. The extent of the glacial outburst deposit is limited to the western part of the aquifer. Farther east, in the upper strata, the predominant depositional unit is outwash.

Borehole geophysical (natural gamma) logs and lithologic logs from a west-east cross section (fig. 3) through the OU1 area illustrate the complex stratigraphic pattern of the overburden. The natural gamma logs show high gamma count readings in boulder and cobble layers and low gamma count readings in well-sorted sand layers with few clay particles (fig. 3A). Interpolated gamma values between borehole logs are provided to help map the subsurface. The lithology from the site is difficult to interpret because of different standards in lithologic log interpretations from drillers (fig. 3B). Nevertheless, some general patterns are visible. Stratigraphic interpretations based on natural gamma logs and lithologic logs are shown in fig. 3C. An upper sand and gravel layer that contains the cobble layer extends through the OU1 area to approximately a 30-ft depth below land surface. In the west, a thick till deposit pinches out to the east. A middle fine-to-medium sand layer extends from PW-2R to EW-1. It appears to pinch out between EW-1 and former (sealed) well MI-63. An underlying gravel and sand layer extends beyond the middle fine sand layer. Two discontinuous coarse-grained layers occur at depths of approximately 65 and $80 \mathrm{ft}$ below land surface.

A partially penetrating river, the Souhegan River, bounds the northwestern part of OU1, and is the major source of recharge in this area (Harte and others, 1999). Farther downstream in OU2, the Souhegan River is a discharge sink for ground water. In areas near the Souhegan River, the groundwater-flow system responds quickly to variations in river stage, recharge from the river, or infiltration from precipitation; therefore, the flow system is highly transient.

Ground water flows to the east at velocities of up to several feet per day in the MSGD aquifer. Ground-water-flow directions can vary daily because of transient hydrologic conditions, which are induced by oscillations in river stage and variations in rates of recharge and discharge (Harte and others, 1997). In the MSGD aquifer, ground-water-flow velocities are highest (greater than $1.5 \mathrm{ft} / \mathrm{d}$ ) in the cobble zone deposit in OU1 and lowest (less than $0.5 \mathrm{ft} / \mathrm{d}$ ) in the basal till throughout the study area.
In OU1, the hydraulic connection between the overburden and fractured bedrock is thought to be high in areas where till is absent. A computed water budget of the net extraction of water inside the barrier indicated bedrock upflow was a large percentage (approximately 50 percent) of the source of water to IW-1 and IW-2 extraction wells (Harte, 2004). Monitoring of continuous water levels in the overburden and bedrock wells showed that net extraction of overburden water from inside the barrier caused bedrock water levels to decrease (Harte, 2005). The presence of PCE in bedrock wells may indicate contaminant transport between the PCE source in the overburden and underlying bedrock.

The transmissive capabilities of the overburden are assumed to exceed that of the fractured bedrock based on limited hydraulic testing of the bedrock. Data on hydraulic properties of the bedrock are limited to a few wells, whereas data on hydraulic properties of the overburden include numerous wells in the study area. Estimates of bedrock hydraulic conductivity from a few bedrock wells indicate a value similar (about $1 \mathrm{ft} / \mathrm{d}$ ) to that of the basal till (HMM Associates, Inc. 1989).

\section{Previous Investigations of Contaminant Sources and Previous Remediation Efforts}

This section focuses on the results of investigations that characterized contaminant source and remediation at OU1. From 1983, when contamination was first detected by NHDES and USEPA, until 2004, ground-water quality of the primarily PCE plume was monitored. Prior to 1999, when the remedial system began operating, PCE concentrations in ground water at OU1 showed modest decreases from 1983 to 1999 (Harte, 2004) probably from a shrinkage in the DNAPL pool from the continuing dissolution of DNAPL into the ground water. After 1999, PCE concentrations decreased at double the rate of preremedial conditions (Harte, 2004).

Three primary source locations have been identified at the former OK Tool facility (Camp, Dresser, and McKee, Inc., 1996) in OU1. They include a floor drain inside the former building near a degreasing tank (called abandoned pit area), a leach field north of the former building, and an area northwest of the former building near a former degreasing tank. The abandoned pit area (southernmost location on fig. 2 and identified as contaminant disposal location in figure inset) is thought to be the primary source input location on the basis of soil concentrations of PCE and ground-water concentrations from nearby vertical profile points (not shown on any figure) and observation wells.

The abandoned pit has been the focus of most investigations of source characterization. Vertical profiling of ground water by use of a direct-push profiler has been performed on multiple occasions by University of Waterloo in 1994, 1995, 


\section{A. Natural gamma log}

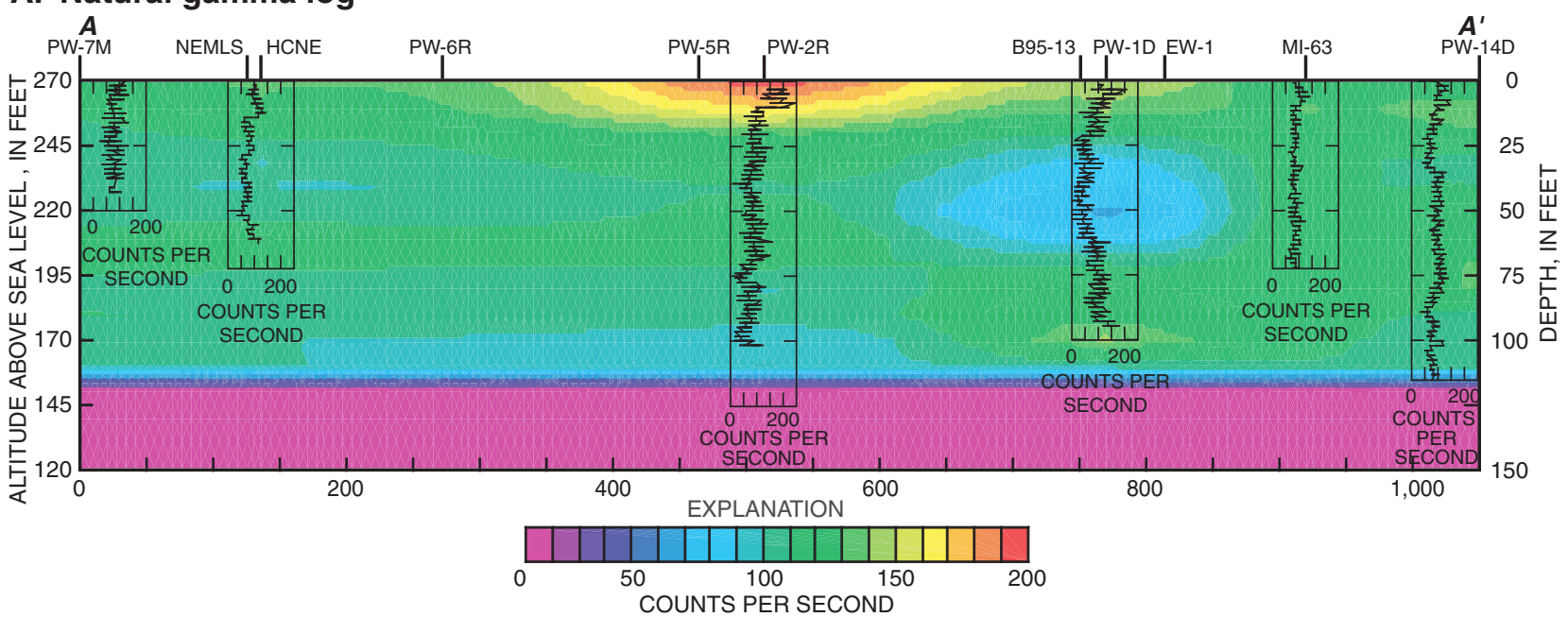

\section{B. Lithology}

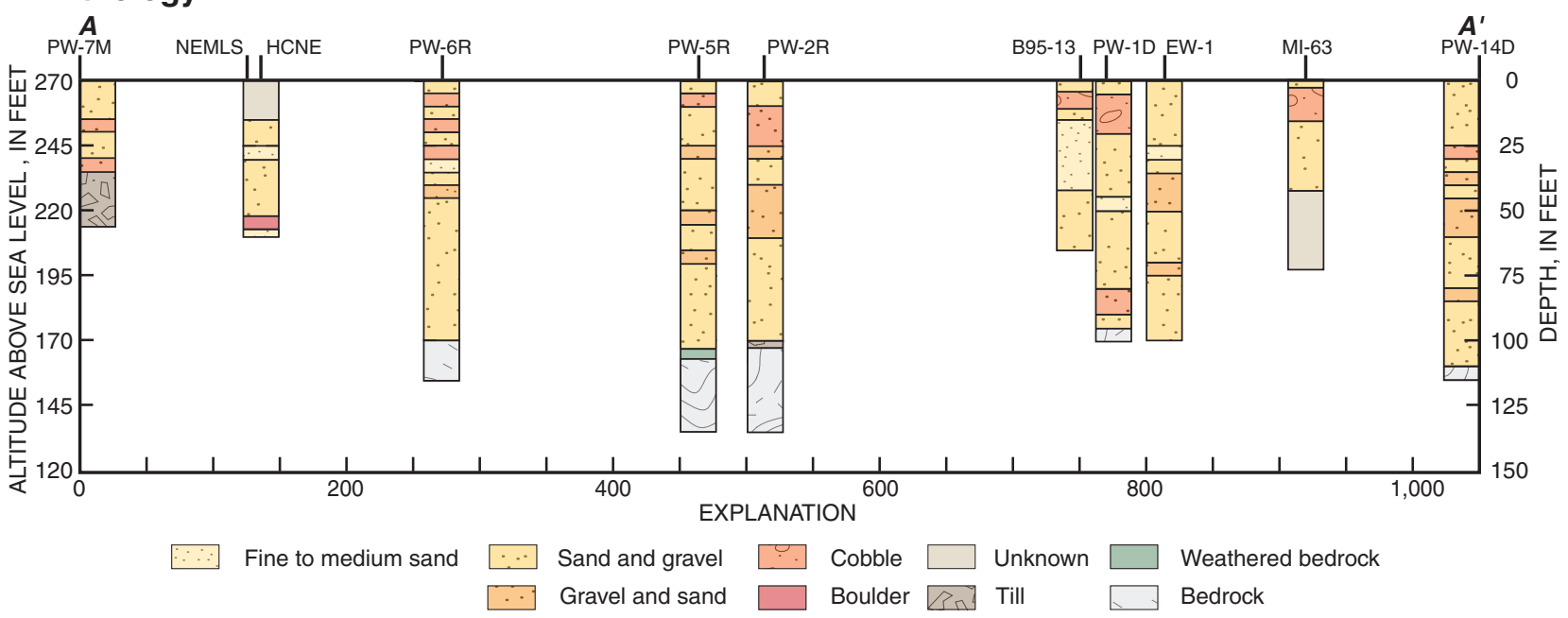

\section{Interpretation of stratigraphy}

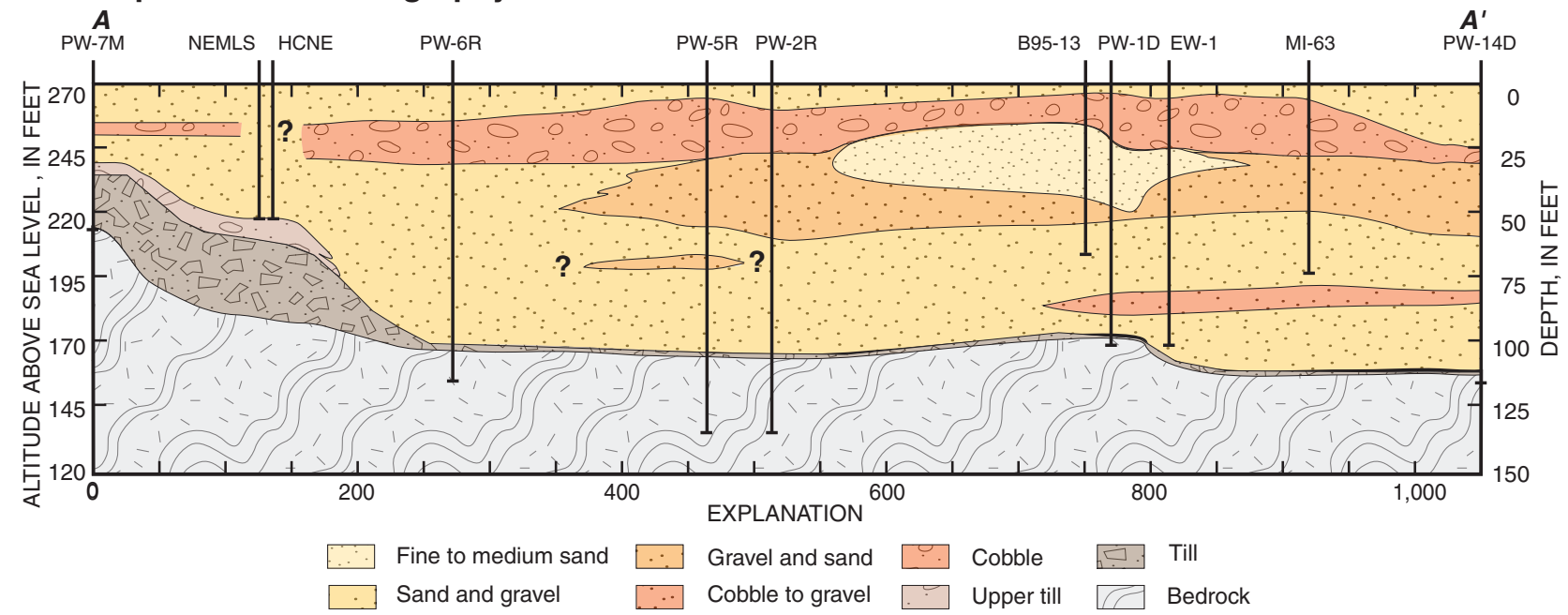

Figure 3. Cross section $A-A^{\prime}$ through Operable Unit 1 (OU1) showing $A$, natural gamma log results, $B$, lithology, and $C$, interpretation of stratigraphy, Milford, N.H. Location of cross section and wells are shown on figure 2. 
1997, and 1998 (Guilbeault and others, 1997, 1998) to map subsurface contamination. High-resolution (close spacing) profiling near the pit was done in 1997 and 1998. In 1994-95, profiling detected PCE concentrations exceeding 100,000 ppb at shallow depths (19 ft below land surface) approximately $20 \mathrm{ft}$ south of the abandoned pit (Camp, Dresser, and McKee, Inc., Federal Programs Corporation, 1995). In 1997, a line of profile points was done about $17 \mathrm{ft}$ downgradient (east) of the pit location where the profiling detected maximum PCE concentrations of approximately 70,000 ppb. Maximum concentrations at any profile location appear to be in 3 to $15-\mathrm{ft}-$ thick intervals at depths of 15 to $50 \mathrm{ft}$ below land surface. The depths of maximum PCE concentrations slope to the northeast with the primary ground-water-flow direction but also are controlled by heterogeneity of the subsurface. In 1998, vertical profile points were done upgradient, lateral, and downgradient to the pit. Profile points to the north and northeast (lateral and downgradient) of the pit detected maximum PCE concentrations exceeding 100,000 ppb at depths less than $40 \mathrm{ft}$ below land surface (Guilbeaut and others, 1998).

Based on profiling results, 17 long-screened (45-ft) wells were installed near the abandoned pit (fig. 2 insert; appendix 1). The assembly of wells is referred to as the INEEL (Idaho National Engineering and Environmental Laboratory) well field, named after the lead agency responsible for installation. In addition to the 17 long-screened wells (fig. 2 insert), 6 multi-level sampler wells (not shown in fig. 2) were also installed. Multi-level samplers had sample intakes at depths of 22, 28, 42, 48, 58.5, and $60.5 \mathrm{ft}$ below land surface.

The well installation near the pit location was part of a demonstration study by INEEL to test Surfactant-Enhanced Aquifer Remediation at Neutral Buoyancy (SEAR-NB) technology to help reduce DNAPL volume (Tetra Tech EM, Inc., 2003). SEAR-NB mobilizes DNAPL through horizontal transport without vertical migration because of the two-step process of surfactant mobilization with neutral buoyancy. The study included collection of two core holes, slug tests of INEEL wells, and a series of primarily conservative interwell tracers tests (CITT) in three zones of the overburden (shallow, middle, and deep). Results of the tracer tests showed significant horizontal and vertical heterogeneity (more than a factor of 10 in hydraulic conductivity) within the well field. Estimates of hydraulic conductivity ranged from 28 to $574 \mathrm{ft} / \mathrm{d}$ (Tetra Tech EM, Inc., 2003) with an average porosity of 0.25 . A partioning interwell tracer test (PITT) also was performed to measure residual DNAPL saturation. Results showed a maximum DNAPL saturation of 15 percent within several layers. Numerical simulations of CITT, PITT, and the planned SEAR$\mathrm{NB}$, were done with a finely discretized transport model. The actual SEAR-NB demonstration was not conducted because of problems with the disposal, after extraction from the subsurface, of the mobilized DNAPL and surfactant, which contains high biological oxygen demand (BOD) concentrations.

A review of the OU1 remedial system by U.S. Environmental Protection Agency (2001) identified the following two problems with the effectiveness of the current (2004) remedial system: (1) uncertainty in the delineation of capture areas of the exterior extraction wells, and (2) inability to reduce DNAPL quantities inside the barrier. The latter is identified on the basis of trends in PCE concentrations inside the barrier at observation wells (PW-6 cluster, fig. 2) between the source area at the INEEL field and interior extraction wells (IW-1 and IW-2). PCE concentrations at PW-6 cluster wells (PW-6S, 6M, 6D, and 6R; fig. 2), as collected and analyzed by New Hampshire Department of Environmental Services (Leah Desmarais, New Hampshire Department of Environmental Services, written commun., 2004), increased after barrier installation. This trend is consistent with a continuous DNAPL source, reduced dilution inside the barrier, and a decrease in ambient groundwater flow.

A review of a 5-year (1998-2003) post-remedial time period of OU1 remedial construction and operation was done by New Hampshire Department of Environmental Services (2003). Data on system operation, aquifer response, and contamination clean-up were synthesized, including the testing and monitoring of the SVE and SP systems in 2002.

The SVE system operated between February 16 through March 19, 2002, and adjacent observation wells were monitored to assess the effect of SVE on the ground water of the overburden and bedrock. The SVE wells are shallow screened (12-27 ft below land surface) and are capable of delivering a maximum negative pressure output of 5 pounds per square inch (psi) by extracting air from the unsaturated zone. One psi is equivalent to $2.3 \mathrm{ft}$ of water. For the test, negative pressure output averaged 2 psi. A maximum pressure response, indicated by a decrease in water level of $2.2 \mathrm{ft}$, was measured at observation well PW-8M. In general, pressure changes increased at most interior shallow wells and decreased slightly (by about 20 percent) with depth (New Hampshire Department of Environmental Services, 2003) during the test. However, shallow well B95-9 screened near the watertable surface and within the cobble zone showed water-level decreases of only $1 \mathrm{ft}$. This change indicates a lateral and vertical decrease in pressure in the cobble layer because of the high permeability of this layer. Wells outside the barrier showed the greatest decrease in water level at depth, converse to wells inside the barrier, which indicates a ground-water connection inside and outside the barrier beneath the barrier wall. Water-level decreases at well clusters PW-5 (inside) and PW-2 (outside) showed similar responses in bedrock wells indicating a connection beneath the barrier through the bedrock, whereas overburden wells showed a muted response in the exterior overburden wells. At the PW-8M (inside) and PW-9M (outside) overburden wells straddling the barrier, the water level decreased by $2.2 \mathrm{ft}$ at PW-8M while decreases at PW-9M were negligible.

The two air sparge wells (SP-1, SP-2) were operated for 2 days (August 15-16, 2002) and observation wells were monitored to measure the response of water levels to air pressure. The air sparge wells increase pressure by adding air to the aquifer. The SP wells are capable of a maximum positive pressure of 25 psi each well. The air sparge wells are report- 
edly screened at 59 to $64 \mathrm{ft}$ below land surface (Peter Borowiec, Camp, Dresser, and McKee, Inc., written commun., 1999). The results of the test show water-level rises of up to $3 \mathrm{ft}$ in deep observation wells and about $1 \mathrm{ft}$ in shallow wells. Interior wells responded the most; exterior wells responded about 30 percent of the interior wells. These results indicate the barrier is hydraulically isolating the interior flow system. Results also showed the greatest responses of water levels to injection at SP-2 and less at SP-1 (New Hampshire Department of Environmental Services, 2003). Well SP-1 is screened near the bedrock surface and probably partially screened in the till, which has a lower permeability than the sand and gravel units of the overburden. The driller log for SP-1 shows a 3-ft sump penetrating the bedrock below the well screen, which could cause a partial loss of air into the bedrock, making SP-1 less efficient in delivering injected air into the overburden.

In September 2003, an insitu chemical oxidation (ISCO) pilot test (U.S. Filter, Inc., 2005) was done in the INEEL text array (fig. 2) to help reduce dissolved VOC concentrations. The ISCO test included injection of 8,400 pounds of potassium permanganate through the targeted DNAPL source zones. Research is ongoing, but as of 2004, decreases in PCE concentration were not detected at nearby PW-6 wells (fig. 2).

\section{Effects of the Remedial System and its Operation on Ground-Water Quality and Flow}

Effectiveness of VOC (primarily PCE) remediation at OU1 is discussed on the basis of monitoring data including water levels and water quality. Selected construction data for the barrier wall are also included to assess the potential for lateral transport in the overburden between interior and exterior barrier areas in OU1.

\section{Hydrogeologic Responses}

This section discusses remedial operation and ambient conditions that affect ground-water flow, solute transport of VOCs, and abatement of VOCs. Ground-water-flow conditions for pre-barrier wall construction, but prior to operation of the remedial system, were discussed in Brayton and Harte (2001). Post-construction ground-water-flow patterns due to the barrier produce an area of focused recharge (river loss) from the Souhegan River to the aquifer in OU1 near well P-2 (fig. 2). In contrast, pre-construction flow patterns show diffuse recharge along the entire Souhegan River reach of OU1. Therefore, ground-water velocities in the shallow overburden where most river loss occurs have increased to accommodate the focused recharge.

Remedial operation affects ground-water flow and solute transport. The extraction of contaminated ground water, treatment, and reinjection alters ground-water flow and solute transport. The distribution and rate of extraction and injection at interior and exterior barrier locations is the primary factor affecting flow and transport. Inside the barrier, different rates of extraction occurred from 1999 to 2003 and reinjection of treated water inside the barrier decreased during that same time. The net rate (extraction minus injection) of extraction inside the barrier generally increased as a result of decreases in interior injection.

Ambient hydrologic conditions affect ground-water levels, gradients, and flow in OU1. Ambient hydrologic conditions include precipitation, evapotranspiration, and river-stage fluctuations from the Souhegan River. Additionally, stresses from ground-water withdrawal wells outside of OU1 also affect ground water in OU1.

Water table (shallow overburden ${ }^{1}$ ) and potentiometric (middle ${ }^{2}$ and deep overburden ${ }^{3}$ ) head maps indicate groundwater-flow patterns in OU1 become complex after the completion of the barrier wall and particularly during the operation of the remedial system. Heads are controlled by ambient recharge boundaries (Souhegan River), flow into discharge areas (OU2 area), seasonal and long-term (more than 1 year) climate trends, the barrier wall, and remedial operations. Under nonoperating conditions in January 2002 (fig. 4), flow, assumed orthogonal to head contours, diverges on the upgradient side of the barrier and converges on the downgradient side of the barrier. Inside the barrier, head gradients are small because of the low rates of horizontal flow into and out of the barrier. When the remedial system is not operating, the horizontal gradient inside the barrier is $0.0011 \mathrm{ft} / \mathrm{ft}$, and outside is $0.0069 \mathrm{ft} / \mathrm{ft}$. Vertical gradients also are small (less than $0.001 \mathrm{ft} / \mathrm{ft}$ ) when the system is not operating.

When the remedial system is operating, as in November 2001, the most prominent water-table-surface feature is the mound created from injection at the recharge gallery outside the barrier in the shallow overburden (fig. 5A). The exact dimensions and elevation of the mound are unknown because of a lack of shallow water-table wells near the gallery but it is likely the gallery raises the water-table surface by several feet. Cones of depression from extraction at EW-1 and EW-2 are small because of the small rates of extraction (typically $25 \mathrm{gal} / \mathrm{min}$ each). Inside the barrier, horizontal gradients increase slightly from $0.0011 \mathrm{ft} / \mathrm{ft}$ (non-operating conditions) to $0.0016 \mathrm{ft} / \mathrm{ft}$ (operating conditions). Similar to EW-1 and EW-2, cones of depression at IW-1 and IW-2 are small because of the small rates of extraction ( $37 \mathrm{gal} / \mathrm{min}$ total), high hydraulic conductivity (exceeding $25 \mathrm{ft} / \mathrm{d}$ ), and lack of data points near the wells.

\footnotetext{
${ }^{1}$ Shallow overburden is defined in this report as depths equal to or less than $40 \mathrm{ft}$ below land surface.

${ }^{2}$ Middle overburden is defined in this report as depths greater than $40 \mathrm{ft}$ and less than or equal to $70 \mathrm{ft}$ below land surface.
}

${ }^{3}$ Deep overburden is defined in this report as depths greater than $70 \mathrm{ft}$ below land surface. 


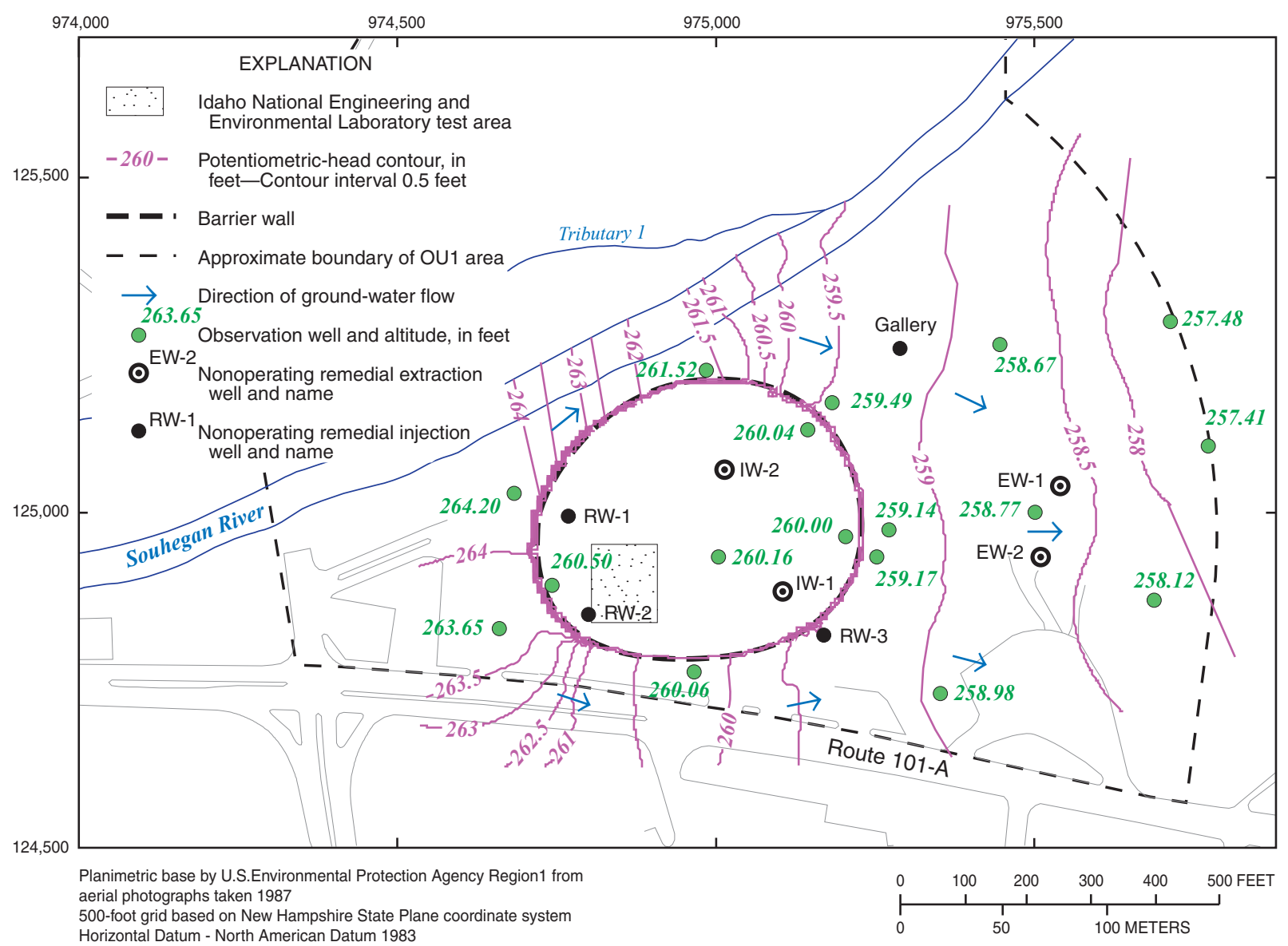

Figure 4. Potentiometric-head contours of middle overburden after barrier construction but under non-operating conditions during low recharge, January 2002, Operable Unit 1 (OU1), Milford, N.H.

Small stagnation areas form on the upgradient side of the recharge gallery, and the downgradient side of the extraction wells at EW-1 and EW-2 whenever the remedial system is operating. The stagnation areas are areas of slow velocity that are problematic for flushing of contaminants in ground water. If concentrations of PCE are high in these areas, PCE transport decreases and high concentrations remain for extended periods of time.

In the middle of the overburden in November 2001 (fig. 5B), the mound from the recharge gallery is not observable because of a lack of data points in that area. Flow is from the gallery area to the extraction wells. Inside the barrier, horizontal gradients are flat in the area between IW-1 and IW-2 from PW-6 to PW-5 well clusters (fig. 2) indicating a slow velocity zone.

In the deep overburden in November 2001 (fig. 5C), flow from the gallery area is more easterly than southerly unlike the middle overburden; this deep ground water in this area is less likely to be captured by EW-1 and EW-2 than ground water in the middle overburden. Inside the barrier, the horizontal gradient between IW-1 and IW-2 is greater in the deep overburden than in the middle overburden, thus indicating a stagnation area is likely to be more prevalent in the middle overburden.

The ambient hydrologic conditions for the head maps shown in figures 4 and 5 are of low recharge periods when water levels were low. Low recharge can be the result of low rates of precipitation and(or) high rates of evapotranspiration. In figures 4 and 5, low recharge is caused exclusively by low rates of precipitation. To better quantify hydrologic conditions for the periods shown in figures 4 and 5, water levels were evaluated based on water-level statistics from long-term (from 1962) monitoring well MI-18 in OU2 (fig. 1). Water levels were ranked from low to high from 1997 to 2004 to provide exceedance rankings for each daily average water level recorded at M-18. Referencing the daily average water level of MI-18 from the day that head data were mapped in OU1 provides an exceedance ranking and insight into recharge conditions. Water-level exceedance was low (less than 18 percent) for January 2002 and November 2001.

A head map of the middle overburden during remedial operations in May 2002 (fig. 6A) represents a high recharge period when water levels were high; water-level exceedance 
A.

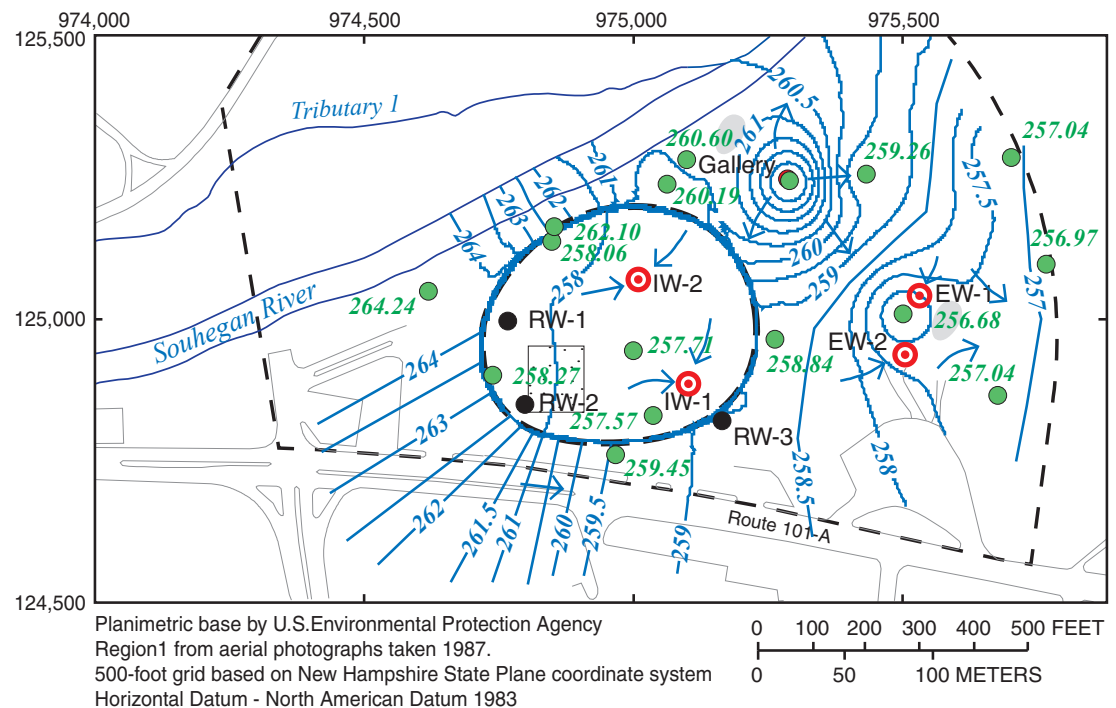

B.

(100 METERS

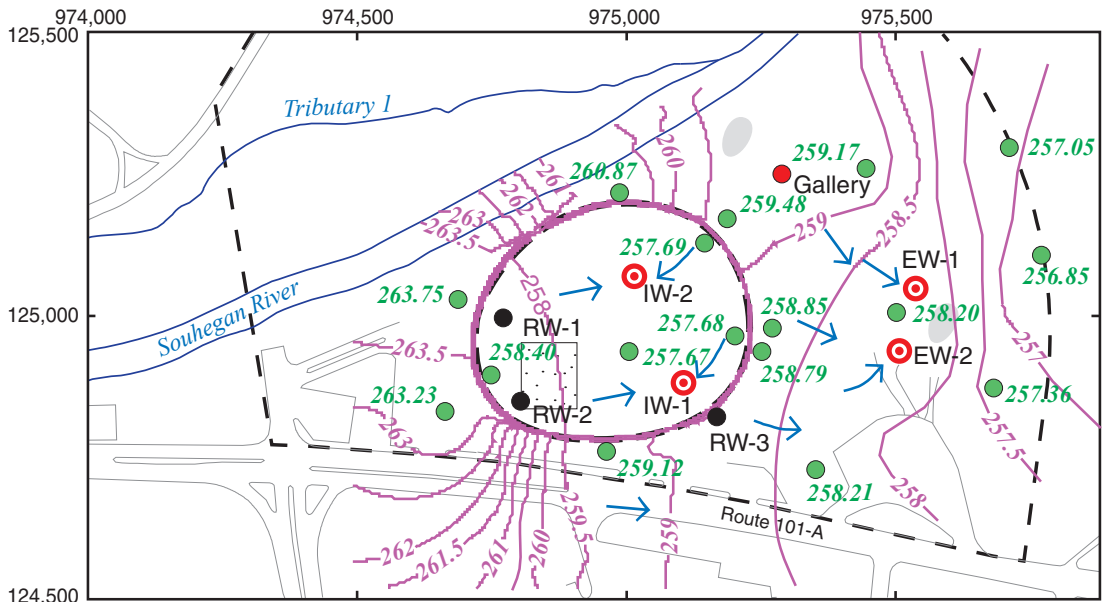

C.

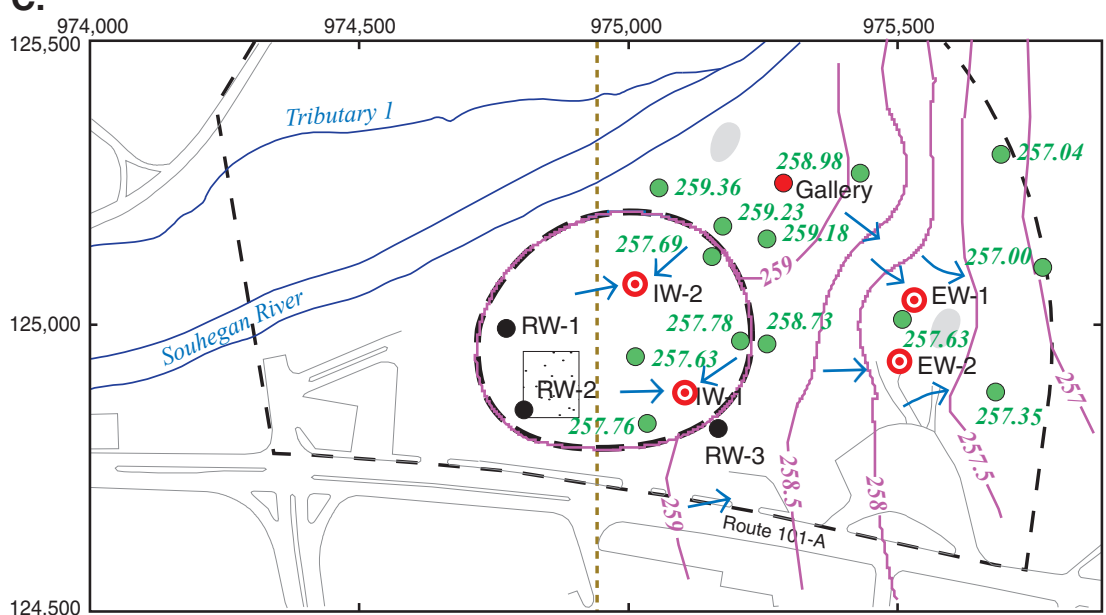

\section{EXPLANATION}

Idaho National Engineering and Environmental Laboratory test area

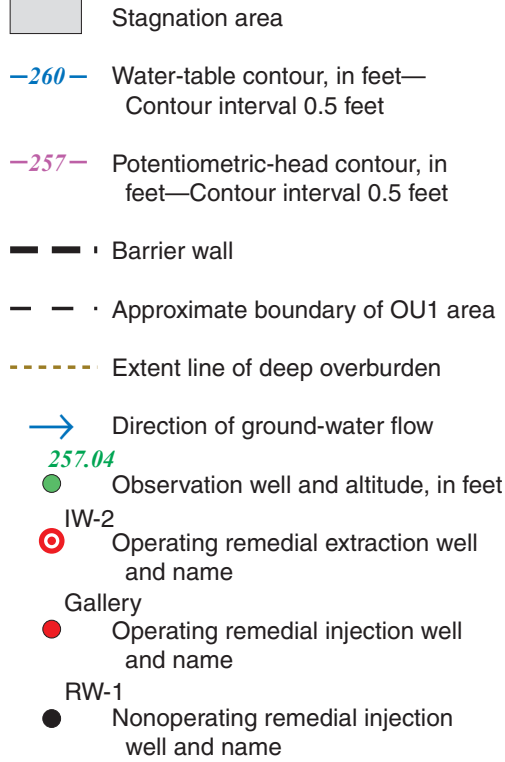

Figure 5. Water-table and potentiometric-head contours for $A$, shallow, $B$, medium, and $C$, deep overburden under operating conditions during low recharge, November 2001, Operable Unit 1 (OU1), Milford, N.H. 


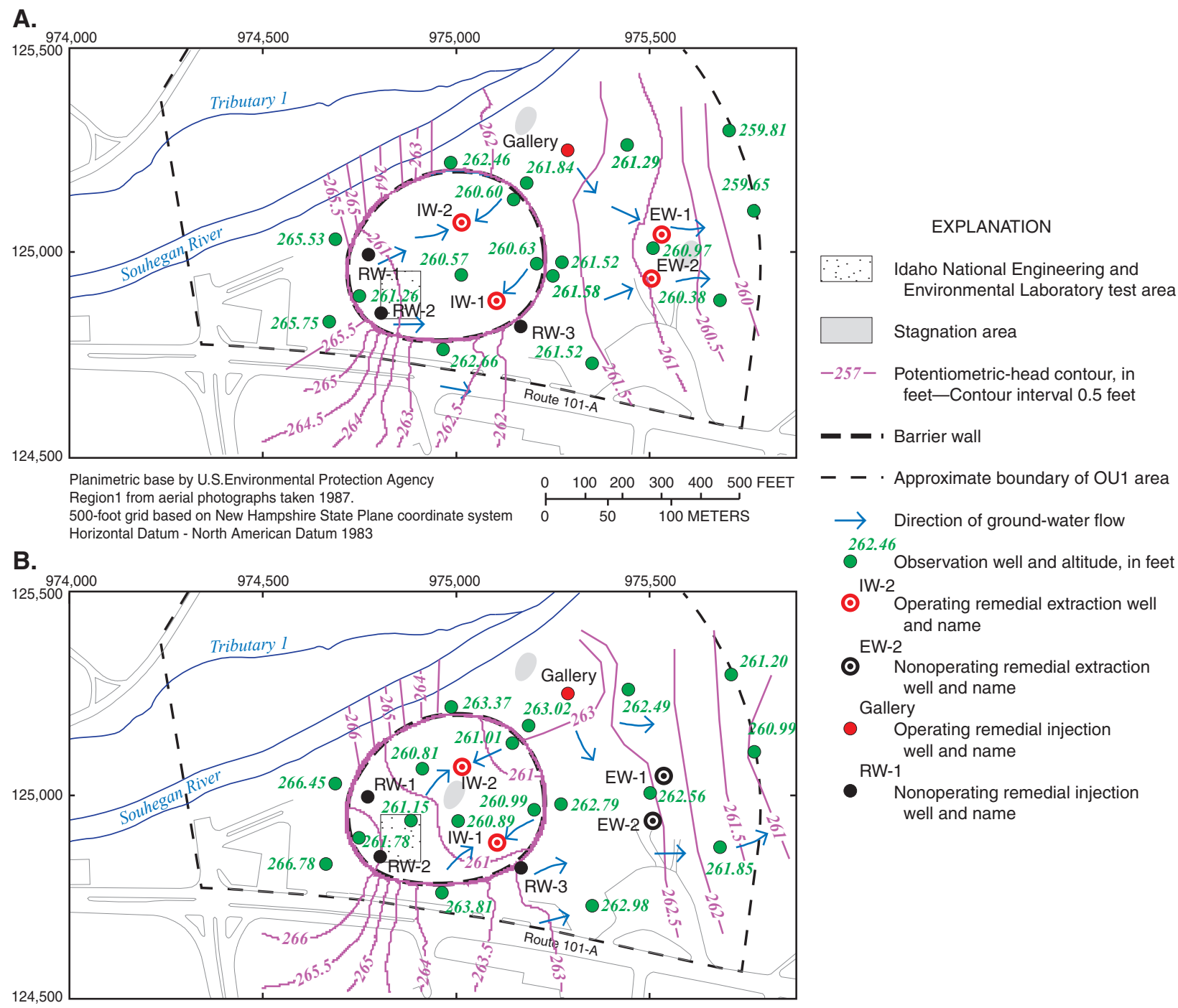

Figure 6. Potentiometric-head contours of middle overburden in a high recharge period under $A$, operations in May 2002 , and $B$, partial operating conditions in April 2004, Operable Unit 1 (OU1), Milford, N.H.

was 83 percent at well MI-18. Outside the barrier, the horizontal hydraulic gradients in the middle overburden are less in May 2002 during a high recharge period than in November 2001 during a low recharge period. This process occurs at OU1 because maximum river loss occurs during low recharge periods as documented in Harte and others (1999). High recharge periods, therefore, correspond with slower groundwater velocities than low recharge periods and larger stagnation areas east of EW-1 and EW-2. Inside the barrier, horizontal gradients are similar between May 2002 and November 2001.

A head map of the middle overburden under partial remedial operation in April 2004 (fig. 6B) represents a high recharge period when water levels were high; water-level exceedance was 91 percent at well MI-18. In April 2004, EW-1 and EW-2 were not operating and interior extraction at
IW-1 and IW-2 increased from 37 to $60 \mathrm{gal} / \mathrm{min}$. Injection at the gallery continued as in November 2001 but at lower injection rates; $60 \mathrm{gal} / \mathrm{min}$ in April 2004 compared to $110 \mathrm{gal} / \mathrm{min}$ in November 2001. Outside the barrier, the horizontal hydraulic gradients in the middle overburden are less in April 2004 than in May 2002 and in November 2001 because extraction ceased. Stagnation areas are eliminated downgradient of EW-1 and EW-2 but still occur upgradient of the gallery. Inside the barrier, horizontal gradients increase because of increased extraction at IW-1 and IW-2. A stagnation area is visible inside the barrier near PW-6 well cluster at the bend in the 261-ft contour (fig. 6B). The stagnation area is not visible in November 2001 (fig. 5B) and May 2002 (fig. 6B) likely because fewer measurement points were available for these periods than the other periods. 
Precipitation effects on ground water in OU1 were examined in Brayton and Harte (2001). Findings from that study showed that the land-surface crown inside the barrier area decreases infiltration of precipitation and recharge to ground water. A 50-percent reduction of recharge was attributed to the crown based on water-level responses to precipitation (water-level accretion method; Rasmussen and Andreason, 1959) after construction of the barrier wall in the fall of 1998. Simulations of ground-water flow and solute transport (Harte, 2004) of transient recharge events indicate that the reduction of recharge from the crown is likely less than 50 percent. Water-level rises in water years 2000-01, correlated to specific precipitation events during stable remedial operation periods (no variation in extraction or injection for several days), indicate that the crown reduces recharge by 15 to 45 percent (mean value of 30 percent) based on the water-level accretion method. The crown likely increases runoff (overland or interflow) and decreases infiltration into ground water from precipitation. Water mounding in the 2.5 -ft-deep trench where B95-9 (fig. 2) is located have been observed after precipitation. The water seems to travel laterally as interflow, and seeps into cracks in the concrete culvert that supports the trench. The base of the trench represents the original land surface before the crown was constructed.

The response of ground-water levels to changes in ambient conditions is useful in assessing connectivity of the aquifer inside and outside the barrier. The proximity of the barrier to the Souhegan River is an important ambient boundary condition to assess connectivity. Fluctuations in river stage and ground-water levels were compared, with daily precipitation data, to identify periods when river-stage fluctuations (specifically increased stage) were measured with no corresponding precipitation event. By excluding periods of snowmelt or thaw, river-stage fluctuations during these periods probably indicate changes in flow from regulations upstream. At the same time, ground-water level rises during this time would indicate that ground-water levels in a well are affected by the river. The purpose of diagnosing ground-water-level changes during this period is to (1) allow for evaluation of barrier wall integrity by comparing whether river-stage fluctuations cause groundwater-level fluctuations inside the barrier, and (2) provide insight into the analyses of ground-water recharge by identifying wells with water levels that are highly correlated with river stage. Several periods were identified, including December 26-29, 1999, December 26-29, 2000, and January 12-19, 2003. All periods had air temperatures below freezing and thus experienced no thawing in the vadose zone. In general, waterlevel responses indicate that the barrier is generally effective in hydraulically isolating the flow through the overburden inside the barrier but the fractured bedrock provides a flowpath from outside to inside the barrier.

From December 26-29, 1999, the remedial system was operating and continuous water-level data were being monitored at wells P-2 (outside barrier, adjacent to river), B95-9 (inside barrier), MI-32 (outside barrier), and MW-16A (outside barrier). Water levels at P-2 rose $0.67 \mathrm{ft}$ from a cor- responding river stage increase. Water levels at MI-32 rose $0.15 \mathrm{ft}$, whereas water levels at B95-9 rose about $0.09 \mathrm{ft}$. Wells MI-32 and B95-9 are similar distances from the river but are outside and inside the barrier, respectively.

From December 26-29, 2000, the remedial system was not operating (shutdown on December 22) and continuous water-level data were being monitored at wells P-2, B95-9, MI-32, and PW-5R (inside barrier, bedrock well). Water levels at well P-2 rose $0.98 \mathrm{ft}$ from a corresponding $1.2 \mathrm{ft}$ river stage increase. Water levels at MI-32 rose $0.32 \mathrm{ft}$, whereas water levels at B95-9 and PW-5R were affected by recovery from remedial system shutdown on December 22.

From January 12-19, 2003, the remedial system was operating (start-up on December 31) and continuous water-level data were being monitored at wells P-2, B95-9, PW-5D (inside barrier), PW-5R, PW-2D (outside barrier, opposite of PW-5D), PW-2R (outside barrier, bedrock well, opposite of PW-5R), PW-8M (inside barrier), and PW-9M (outside barrier, opposite of PW-8M). Water levels at well P-2 rose $1.3 \mathrm{ft}$ from a corresponding $1.7 \mathrm{ft}$ river stage increase, as did water levels at PW-9M, which indicates a similar response of the aquifer at P-2 and PW-9M since they are at similar distances from the river. Water levels inside the barrier at PW-8M, opposite PW-9M, show no increase. Water levels at PW-2D, PW-2R, and PW-5R show a slight increase of 0.29 , 0.25 , and $0.10 \mathrm{ft}$, respectively.

Continuous monitoring of water levels during remedial system changes, particularly when extraction or injection begins after periods (days to weeks) of no operation, provides information on ground-water flow and implications for solute transport and remediation. Examination of remedial operations and the response of ground-water levels to remediation also support the conclusion that the low-permeability barrier restricts ground-water flow in the overburden but that the fractured bedrock provides a path of flow from outside to inside the barrier.

Extraction at interior wells IW-1 and IW-2 cause waterlevel drawdowns in descending priority from greatest to least (1) interior overburden wells (B95-9, PW-8M, and PW-5D), (2) interior bedrock wells (PW-5R), (3) exterior bedrock wells (PW-2R), and (4) exterior overburden wells (PW-2D). This priority indicates effective hydraulic containment in the overburden. A uniform drawdown inside the barrier also indicates little horizontal inflow into the interior barrier area through the overburden. Several periods are discussed in the next section to further illustrate flow processes in OU1.

In June 2001, a total net extraction rate of $31 \mathrm{gal} / \mathrm{min}$ from the two interior extraction wells (IW-1 and IW-2) caused a 2-ft decrease at B95-9, and similar decreases at PW-8M, and PW-5D (fig. 7). In contrast, water-level drawdown at PW-9M was negligible indicating the barrier wall effectively retards flow at this location. Water-level drawdown was measurable, about $0.5 \mathrm{ft}$., at exterior overburden well PW-2D, before precipitation and subsequent recharge increased water levels. However, the decrease at PW-2D is less than the decrease at interior bedrock well PW-5R (1.1 ft), and was less than the 


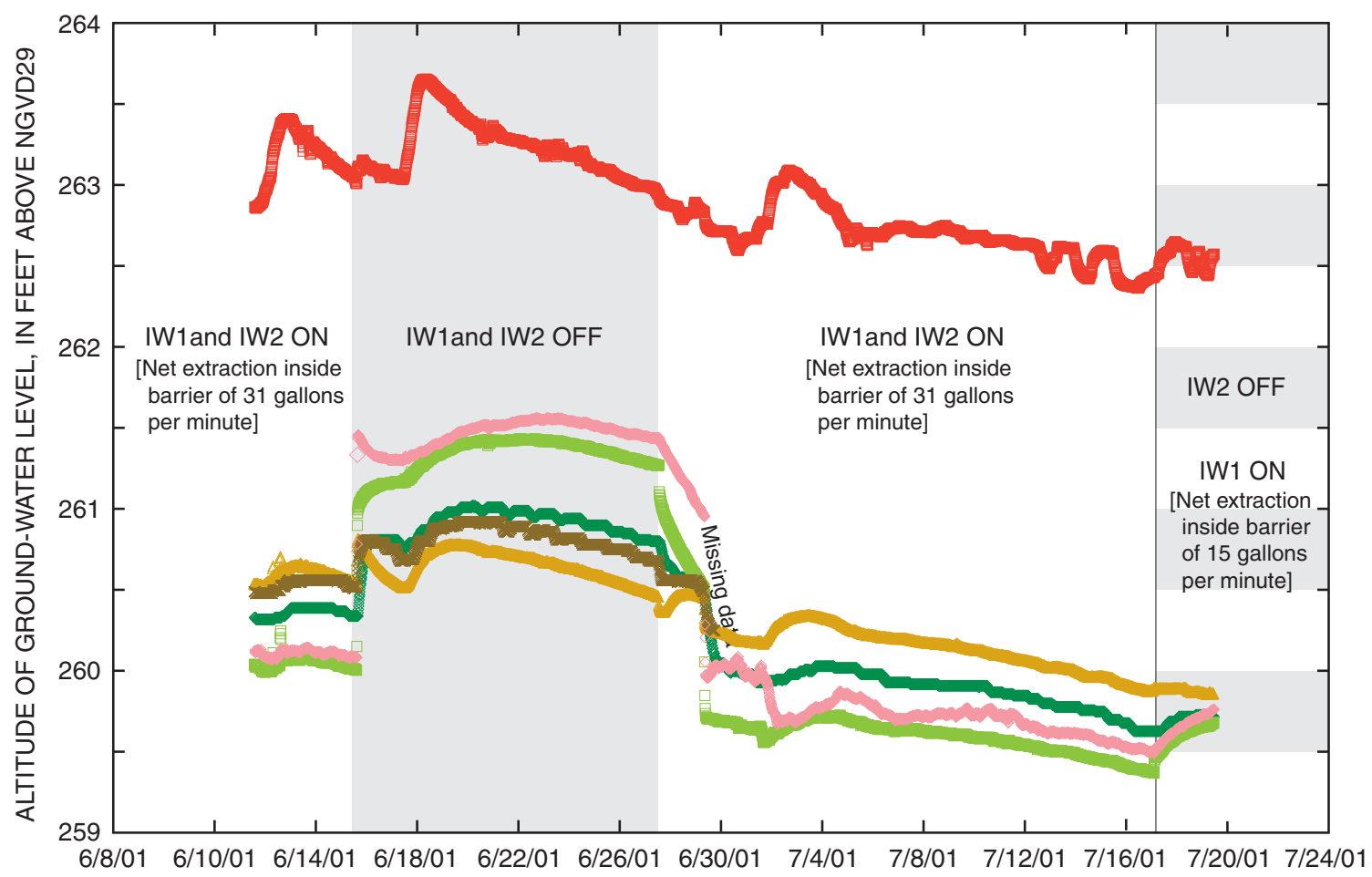

EXPLANATION

Interior well (IW) OFF
Interior well (IW) ON
WATER LEVELS IN OBSERVATION WELLS
PW-2R, exterior
PW-2D, exterior
PW-5R, interior
PW-5D, interior
PW-8M, interior
PW-9M, exterior

Figure 7. Water-level drawdowns from interior extraction at continuously monitored observation wells, Operable Unit 1 (OU1), Milford, N.H. Well locations are shown on figure 2.

initial decrease at exterior bedrock well PW-2R. This decrease in water-level drawdown indicates that the mechanism for flow between interior and exterior areas is likely through the fractured bedrock, and that the bedrock is hydraulically connected to the overburden. Head, vertical gradient, and potential flow direction between the bedrock and overburden are affected by the interior extraction. Before extraction, downward vertical gradients exist between the overburden and bedrock inside the barrier. After extraction begins, upward vertical gradients exist indicating recharge from the bedrock to the overburden. A schematic diagram of this process is shown in figure 8.

From December 31, 2002 to January 20, 2003, a total net extraction of $60 \mathrm{gal} / \mathrm{min}$ from the two interior extraction wells (IW-1 and IW-2) caused water levels to decrease $3.9 \mathrm{ft}$ at B95-9, with similar decreases at PW-8M, and PW-5D. Water- level drawdown at PW-9M was again negligible indicating the barrier wall effectively slows flow at this location. Water-level drawdown was about $0.5 \mathrm{ft}$. at exterior overburden well PW-2D, which was similar to drawdown observed in June 2001. Water levels decreased at interior bedrock well PW-5R by $2.5 \mathrm{ft}$ and at exterior bedrock well PW-2R by $1.1 \mathrm{ft}$. The increased drawdowns in both bedrock wells (PW-5R and PW-2R compared to exterior overburden well PW-2D) indicate that the increased internal extraction is being supplied by increased flow from the bedrock.

Water-level decreases from exterior extraction wells EW-1 and EW-2 are negligible at exterior monitored wells PW-2D and PW-2R. Total extraction rates are typically 30$50 \mathrm{gal} / \mathrm{min}$. Because of the high rate of ground-water flow in the exterior area and high hydraulic conductivity, extraction 


\section{A. Nonoperating with no extraction}

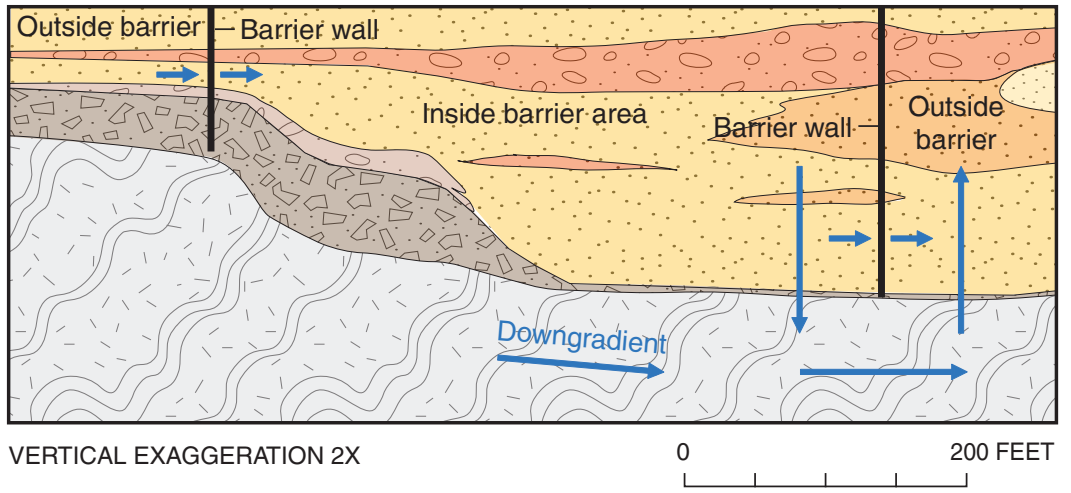

\section{B. Operating with extraction}

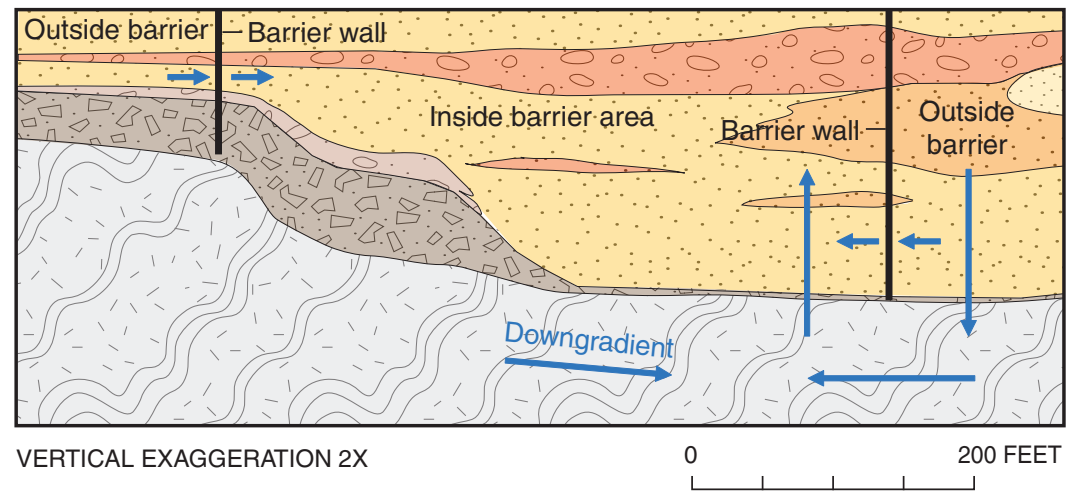

EXPLANATION

Fine to medium sand

Sand and gravel

Gravel and sand

Cobble to gravel

Direction of ground-water flow

Figure 8. Schematic diagram of ground-water flow patterns between the overburden and bedrock inside and outside the barrier area for $A$, non-operating extraction conditions, and $B$, operating conditions, Operable Unit 1 (OU1), Milford, N.H.

at exterior wells intercepts flow rather than induces large drawdown. These conditions help to maintain inward gradients across the barrier.

An inward horizontal gradient across the barrier is important to contain solute transport of VOCs inside the barrier. When there is no net extraction (net extraction of zero), the mean horizontal gradients are outward in the overburden and bedrock from the barrier area. Small net extraction rates (less than $10 \mathrm{gal} / \mathrm{min}$ ) also can produce conditions with outward gradients during medium to high recharge periods (Harte, 2004).

Extraction rates inside the barrier of $30 \mathrm{gal} / \mathrm{min}$ and greater are effective in maintaining inward horizontal hydraulic gradients toward the interior barrier area and reducing the potential for transport of PCE outside the barrier. For example, during water year 2001 and 2003, (between PW-5 (inside) and PW-2 (outside) cluster wells), the mean horizontal head gradient between PW-5D (inside) and PW-2D (outside) was $-0.00160 \mathrm{ft} / \mathrm{ft}$ or a head difference of $-0.77 \mathrm{ft}$ (negative means inward) for water year 2001 and $-0.0401 \mathrm{ft} / \mathrm{ft}$ or a head difference of $-1.92 \mathrm{ft}$ for water year 2003 . The increased inward gradient for water year 2003 was a result of increased extraction (specifically net extraction) inside the barrier from $18.5 \mathrm{gal} / \mathrm{min}$ in 2001 to approximately $62 \mathrm{gal} / \mathrm{min}$ in 2003 .

Horizontal-head gradients in the bedrock between interior and exterior barrier areas are less than gradients in the overburden and, consequently, are more sensitive to variations in interior net extraction rates. Outward horizontal-head gradients in the bedrock between PW-5R and PW-2R occurred when interior extraction took place on 35 days in water year 
2001 (net extraction rate of $18.5 \mathrm{gal} / \mathrm{min}$ ) but only 3 days in water year 2003 (net extraction of $62 \mathrm{gal} / \mathrm{min}$ ). The mean horizontal head gradient between PW-5R and PW-2R was $-0.0025 \mathrm{ft} / \mathrm{ft}$ or a head difference of $-0.12 \mathrm{ft}$ for water year 2001 and $-0.0079 \mathrm{ft} / \mathrm{ft}$ or a head difference of $-0.36 \mathrm{ft}$ for water year 2003.

Injection at the recharge gallery creates a water-table mound several feet high that spreads towards the river. This localized mounding affects local ground-water flow by reducing the flushing of river water into this part of the aquifer. Water-level increases from injection into the recharge gallery (fig. 2) are noticeable at P-2 well during low-recharge conditions. Injection rates of $90 \mathrm{gal} / \mathrm{min}$ at the gallery caused a water-level rise of $0.3 \mathrm{ft}$ at well P-2 during low-recharge conditions in September 2002. Well P-2 is $190 \mathrm{ft}$ from the gallery.

Injection at well RW-3 has little affect on ground-water levels. Water-level increases from injection at shallow (less than $30 \mathrm{ft}$ deep) injection well RW-3 (fig. 2) is negligible at PW-2D located about $200 \mathrm{ft}$ away. The rate of injection at RW-3 ranges from 5 to $25 \mathrm{gal} / \mathrm{min}$.

\section{Ground-Water Quality}

Ground-water quality in OU1 is affected by natural and anthropogenic factors. The primary anthropogenic factor is the remedial system. The remedial system and other factors affect the overall ground-water chemistry and contaminant distribution. In this section, the general ground-water chemistry is discussed first and VOC distribution and trends is discussed second. Ground-water chemistry includes a discussion of major ions, metals, and total organic carbon. The VOC discussion focuses on the primary VOCs detected in OU1.

\section{Water Chemistry}

The general chemistry of ground water in the OU1 area is affected by the chemistry of the Souhegan River water that recharges the aquifer, infiltration of precipitation through the soils, road salting activities along Route 101, the geology of the subsurface materials, and remedial operation of wells and construction materials of the barrier wall. Ground-water residence time and flowpath length and direction are also a major factor in water chemistry. At several wells, well-construction materials, such as grout, in the annulus space of the well borehole also affect water chemistry.

The general chemistry of sampled water from remedial extraction wells was analyzed in spring 2004 to identify if there are major differences in chemistry of waters between interior extraction wells (IW) wells and exterior extraction (EW) wells given the different capture areas ${ }^{4}$ of the wells. Water samples were analyzed for major cations, anions, metals, total organic carbon, and VOCs by USEPA, Region 1 Laboratory. On April 28, 2004, water samples were collected

\footnotetext{
${ }^{4}$ The term capture areas used in this report refers to the three-dimensional volume of aquifer contributing water to extraction wells.
}

at the OU1 plant. The water collected from the OU1 plant was derived from individual active remedial extraction wells (IW-1, IW-2, EW-1, and EW-2), called influent water, and from the combined processed water, remediated for VOCs, and subsequently injected into the recharge gallery, called effluent water. The effluent water was sampled to determine whether water being injected into the aquifer has a different chemical signature than ambient water in the area of the recharge gallery.

Specific conductance of water samples from remedial wells except IW-2 are generally high (greater than $300 \mu \mathrm{S} / \mathrm{cm}$ ) and exceed the mean concentrations of specific conductance from shallow overburden, deep overburden, and bedrock observation wells (table 2) in OU1. The cause of elevated specific conductance in water samples from remedial wells is likely because of location. Remedial wells IW-1 and EW-2 are close to Route 101 and capture the highest amount of water affected by road-salting, whereas most samples from observation wells are from wells north of EW-1 that receive along flowpaths emanating from the river area that are less affected by road salting. Of the 611 samples analyzed for specific conductance, 466 samples (76 percent of samples) had concentrations less than $337 \mu \mathrm{S} / \mathrm{cm}$, which was the concentration measured at EW-2, and 398 samples (65 percent of samples) had concentrations less than $252 \mu \mathrm{S} / \mathrm{cm}$, the concentration measured at EW-1. Most samples from observation wells with concentrations exceeding $337 \mu \mathrm{S} / \mathrm{cm}$ are from wells near Route 101 that receive flowpaths from that area.

Some samples with high specific conductance are from wells farther away from the road, which should be less affected by road salting. These samples are affected by grout contamination at the well and have anomalously high $\mathrm{pH}$ (greater than 8.5). One additional well (PW-2S) had high specific conductance values (exceeding $600 \mu \mathrm{S} / \mathrm{cm}$ ) from samples in 1999. Well PW-2S is a shallow well and constructed with no cement grout in the annulus spacing of the borehole. It is possible, given this well is less than $50 \mathrm{ft}$ from the barrier, that the water chemistry is affected by the slurry of the barrier. The $\mathrm{pH}$ of samples from PW-2S were all less than 7, and indicate the specific conductance is unaffected by grout contamination but potentially affected by slurry contamination from the barrier because samples showed no corresponding increase in $\mathrm{pH}$ with high specific conductance. The $\mathrm{pH}$ of the slurry, when mixed with ambient water from the site, was approximately 7 (Camp, Dresser, and McKee, Inc., written commun., 1998). Specific conductance of the slurry was not directly measured but values of specific conductance of water in contact with bentonite (the material comprising the slurry) were measured at approximately $470 \mu \mathrm{S} / \mathrm{cm}$.

The specific conductance of effluent water injected into the recharge gallery $(303 \mu \mathrm{S} / \mathrm{cm})$ exceeds the ambient specific conductance from the river $(90.5 \mu \mathrm{S} / \mathrm{cm})$ and ground water upgradient from the gallery $(120 \mu \mathrm{S} / \mathrm{cm})$. Therefore, the relatively high specific conductance of injected water is identifiable in ground water as a tracer at locations downgradient of the gallery. 
Table 2. Summary of inorganic and selected volatile organic compounds, Operable Unit 1 (OU1), Savage Municipal Well Superfund site, Milford, N.H.

[USGS, U.S. Geological Survey; site type names explained in abbreviation section of report; locations of all wells shown in figure 2; IW, interior extraction well; EW, exterior extraction well; --, no data; source of data: U.S. Environmental Protection Agency, Region 1 (1999); wells affected by grout contamination excluded from statistical summary; $\mu \mathrm{S} / \mathrm{cm}$, microsiemens per centimeter at 25 degrees Celsius; $\mathrm{mg} / \mathrm{L}$, milligrams per liter; $\mu \mathrm{g} / \mathrm{L}$, micrograms per liter; >, greater than; <, less than; , approximate]

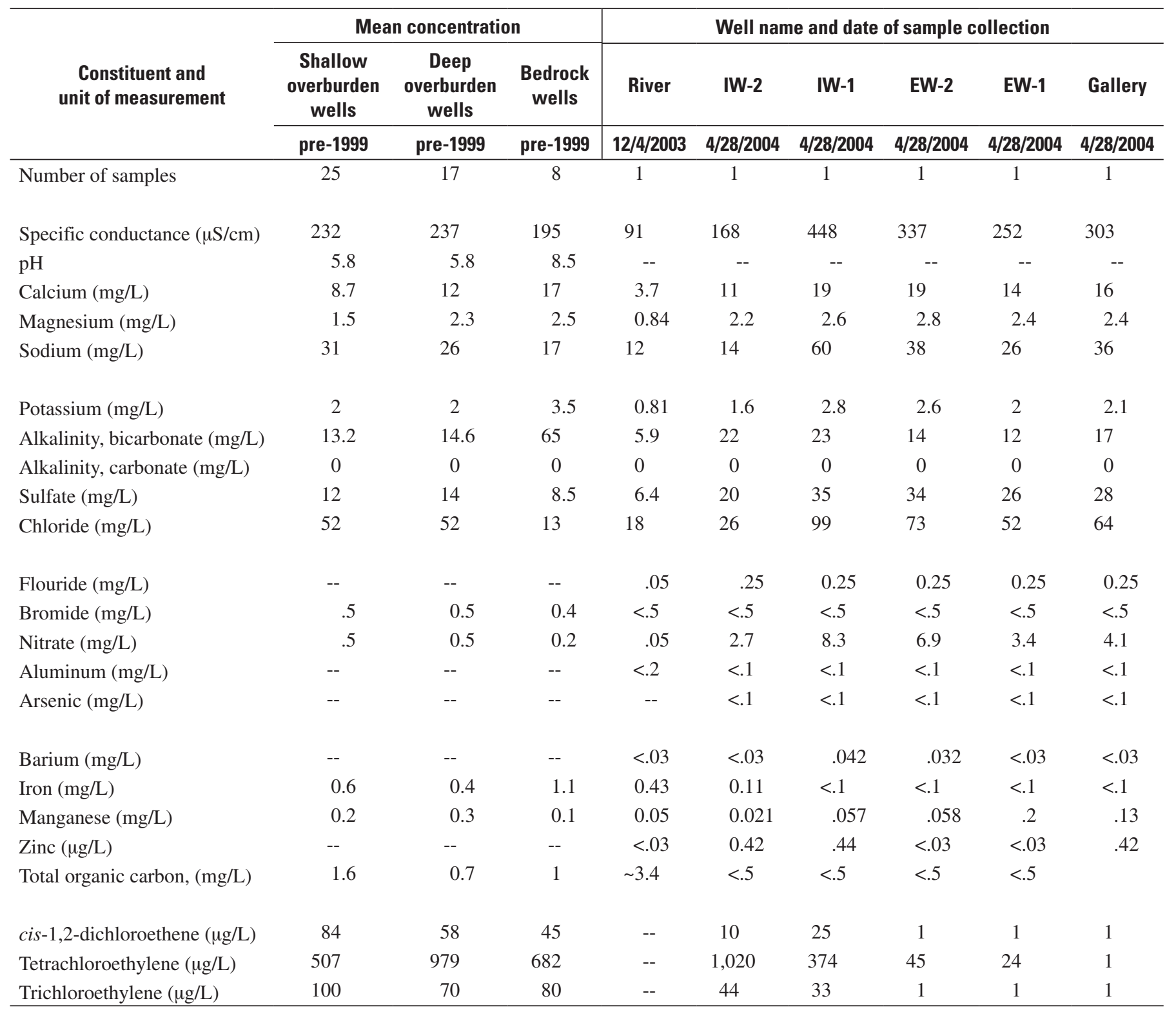


Specific-conductance values (fig. 9) from samples from cluster wells (PW-12 and PW-13) downgradient from the recharge gallery show large increases in specific conductance since the barrier construction in November 1998, and start of remedial operations in March 1999. Samples from wells B95-3 (fig. 9B), PW-3S (fig. 9A) and PW-3D (fig. 9C) upgradient from the gallery show little increase. The specific conductance of samples from the PW-12 well cluster steadily increases from the early spring of 1999 for PW-12S (fig. 9A), the fall of 1999 for PW-12M (fig. 9B), and the late spring of 2000 for PW-12D and PW-12R (fig. 9C). The lag time in specific conductance increases with depth is controlled by increased travel times because the injected water enters at the water-table surface and must travel increasingly long distances to intersect the deeper wells. The specific conductance of samples from the PW-13 cluster steadily increase from the early spring of 2000 for PW-13S (fig. 9A), PW-13M (fig. 9B), and PW-13D (fig. 9C) indicating vertical mixing of ground water between the gallery and these wells. The increase in specific conductance is greatest at PW-13S (fig. 9A), less at PW-13M (fig. 9B), and the least at PW-13D (fig. 9C) indicating dilution occurs with depth.

Ground-water seepage velocities were estimated by identifying increases in specific-conductance at downgradient wells from injection in the gallery. By use of a simple average seepage velocity calculation (Zheng and Bennett, 1995, p. 6, eq. 1-6), given the timing of increases in specific conductance and the travel distances, an approximate ground-water (seepage) velocity of $1 \mathrm{ft} / \mathrm{d}$ was computed for all PW-12 and PW-13 wells except PW-12S, which had a computed velocity of $5 \mathrm{ft} / \mathrm{d}$.

The specific conductance of water from well PW-14M shows negligible increase in specific conductance since 1999. A possible cause for this negligible increase is that travel times to PW-14M from the gallery exceed 4 years.

Total organic carbon (TOC) is an important constituent to examine because anaerobic degradation of aliphatic organic compounds, such as PCE, are electron-donor limited and TOC is the primary source of carbon in the absence of anthropogenic carbon sources (U.S. Environmental Protection Agency, 1999). TOC concentrations at remedial wells were all below USEPA detection levels $(0.5 \mathrm{mg} / \mathrm{L})$. TOC concentrations are generally low in OU1 from subsurface sediments (Camp, Dresser, and McKee, Inc., 1996) and ground water (Harte and others, 2001). TOC concentrations are slightly higher (approximately $3 \mathrm{mg} / \mathrm{L}$ ) in the river and some shallow wells adjacent to the river than in other wells. Historically, the river and PW-6 well cluster have had the highest TOC concentrations, exceeding $2 \mathrm{mg} / \mathrm{L}$.

Metal concentrations (aluminum, barium, iron, manganese, and zinc) were typically low (below detection levels) for most constituents from remedial well water samples. Iron concentrations from remedial well samples are less than mean concentrations from shallow overburden, deep overburden, and bedrock observation wells (table 2).
Major cations and anion concentrations of remedial wells indicate lowest concentrations in samples from IW-2 (table 2). Specific conductance was also the lowest at IW-2. In contrast, the highest concentrations of cations, anions, and specific conductance occurred in samples from IW-1.

The dominant cation of water from remedial wells is sodium, and the dominant anion is chloride. Sodium and chloride concentrations from remedial well samples closely correlate (coefficient of determination of 0.97). The likely reason for the strong relation between sodium and chloride concentrations is that these constituents are derived from roadsalt dissolution.

Linear regression of sodium and chloride concentrations shows that the slope of the regression line (0.60) is similar to the ratio of molecular weight of sodium and chloride (0.65) found in salt. This relation indicates that even for low concentrations, such as that found at IW-2, salt affects the water chemistry. Sodium and chloride concentrations for shallow and deep overburden, bedrock, river, and remedial wells (table 2) indicate that the ratio of the mean concentration for sodium and chloride are near 0.65 except for samples from bedrock. Bedrock water samples show proportionally higher sodium to chloride concentrations indicating dissolution of sodium-bearing bedrock minerals contributes to the increase in sodium concentrations.

The proportional (percent) concentration of major cations and anions, in milliequivalents per liter, are shown in trilinear plots (figs. 10 and 11). Milliequivalents per liter are obtained from the product of the constituent (cation or anion) concentration and its ionic charge, divided by the formula weight of the cation or anion. The percentage of a specific cation concentration to total cation concentration is plotted on the left triangle, and the percentage of a specific anion concentration to total anion concentration is plotted on the right triangle. The middle triangle combines the percent cation or anion concentration. Trilinear plots are useful in characterizing water chemistry (type) because the dominant cation or anion is easily distinguishable.

Water types of the remedial wells are similar and indicative of a sodium-chloride water type for wells IW-1, EW-1, and EW-2 and calcium-sodium chloride water type for IW-2. The most dissimilar water chemistry is between IW-1 and IW-2 because the percentage of sodium varies the most between these samples. Water samples from IW-1 have the highest percentage of sodium, whereas IW-2 samples have the lowest (table 2).

The remedial well water chemistry is most similar to the water chemistry from the deep overburden (fig. 11) and the water chemistry from some shallow overburden (fig. 10) wells based on trilinear plots. However, the water chemistry of the overburden observation wells shows greater variation than the water chemistry from the remedial wells (fig. 10). Samples from some deep overburden wells (PW-6D and PW-10D) contain high calcium, sulfate, and bicarbonate concentrations (relative to other cation or anion concentrations) and are likely contaminated by grout. Samples from some shallow 
A.

B.

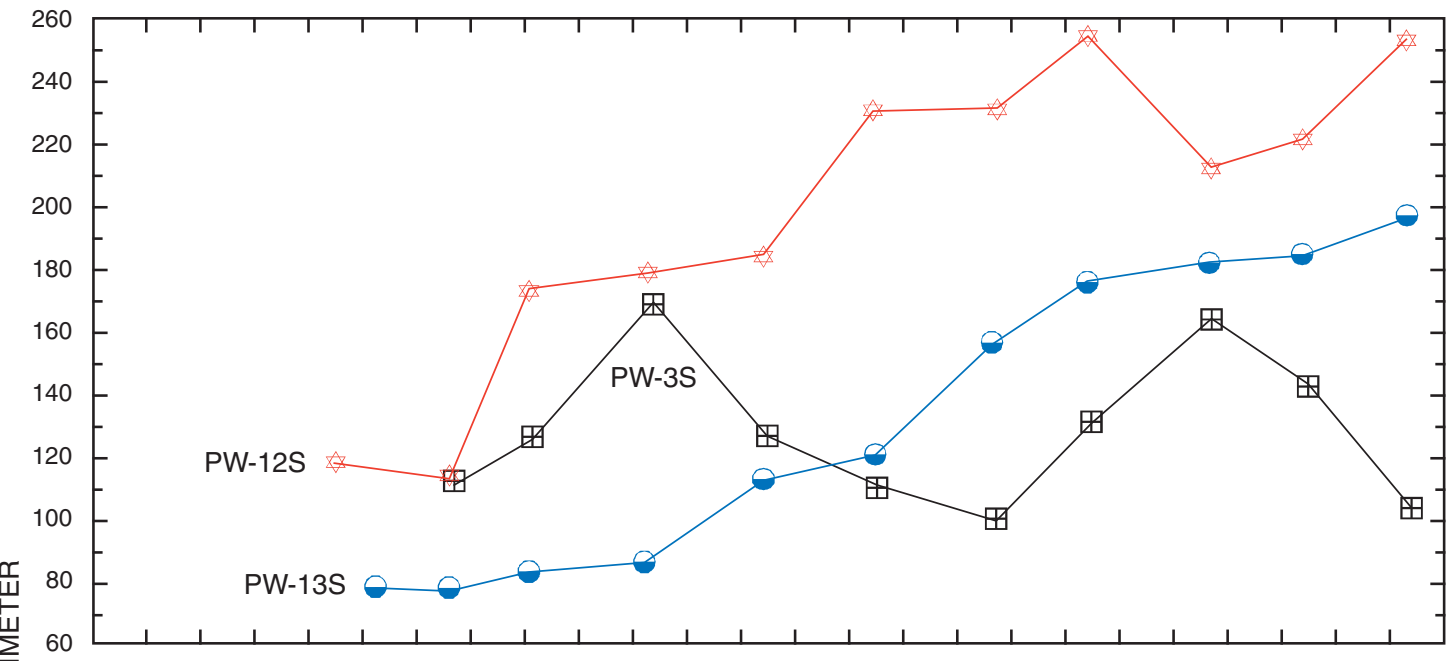

C.
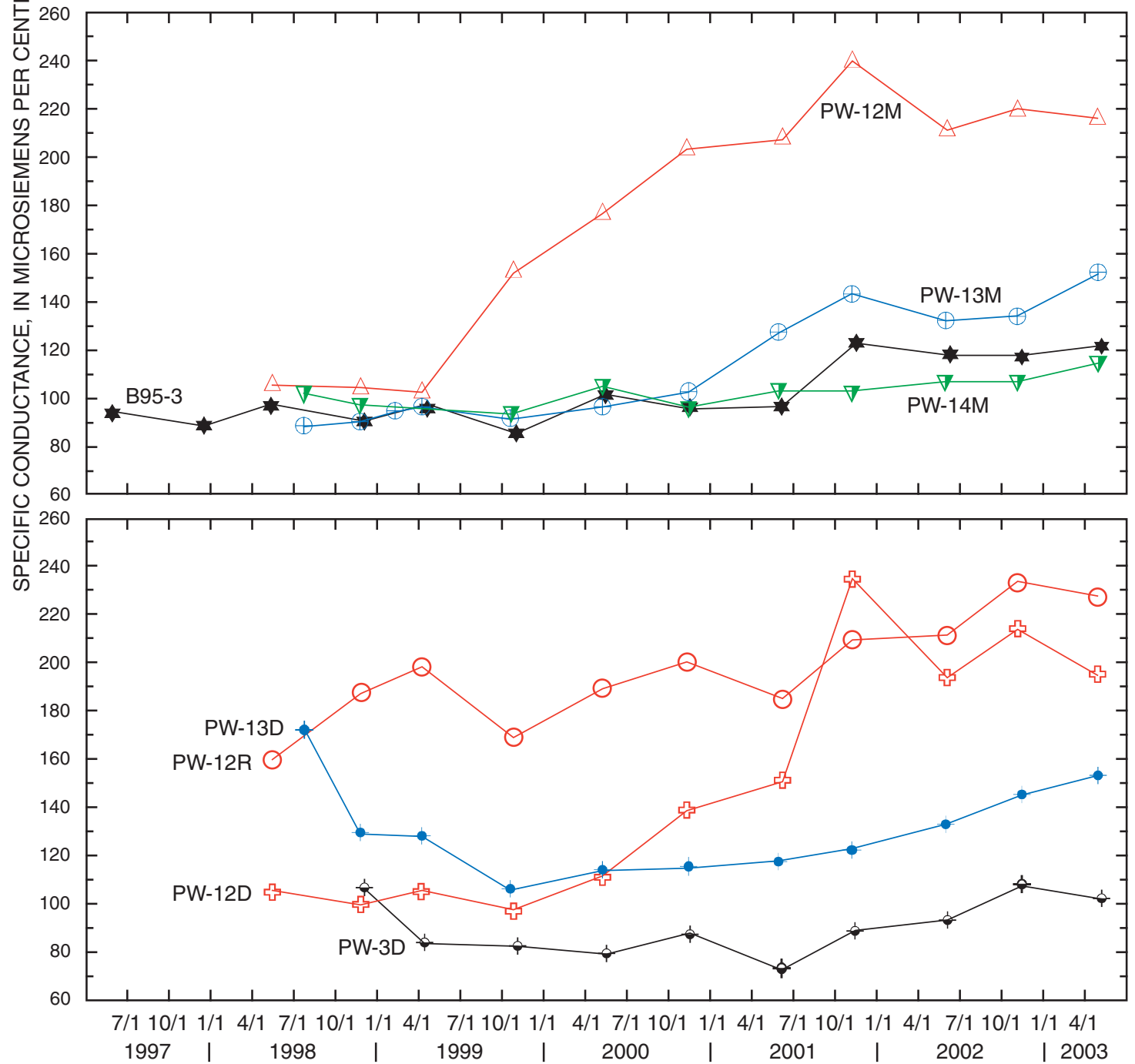

Figure 9. Specific conductance for selected observation-well clusters in Operable Unit 1 (OU1), Milford, N.H. $A$, shallow (S) overburden wells; $B$, middle (M) overburden wells and B95-3; and $C$, deep (D) overburden and bedrock (R) wells. Lines color coded by well cluster. Location of wells shown on figure 2. 


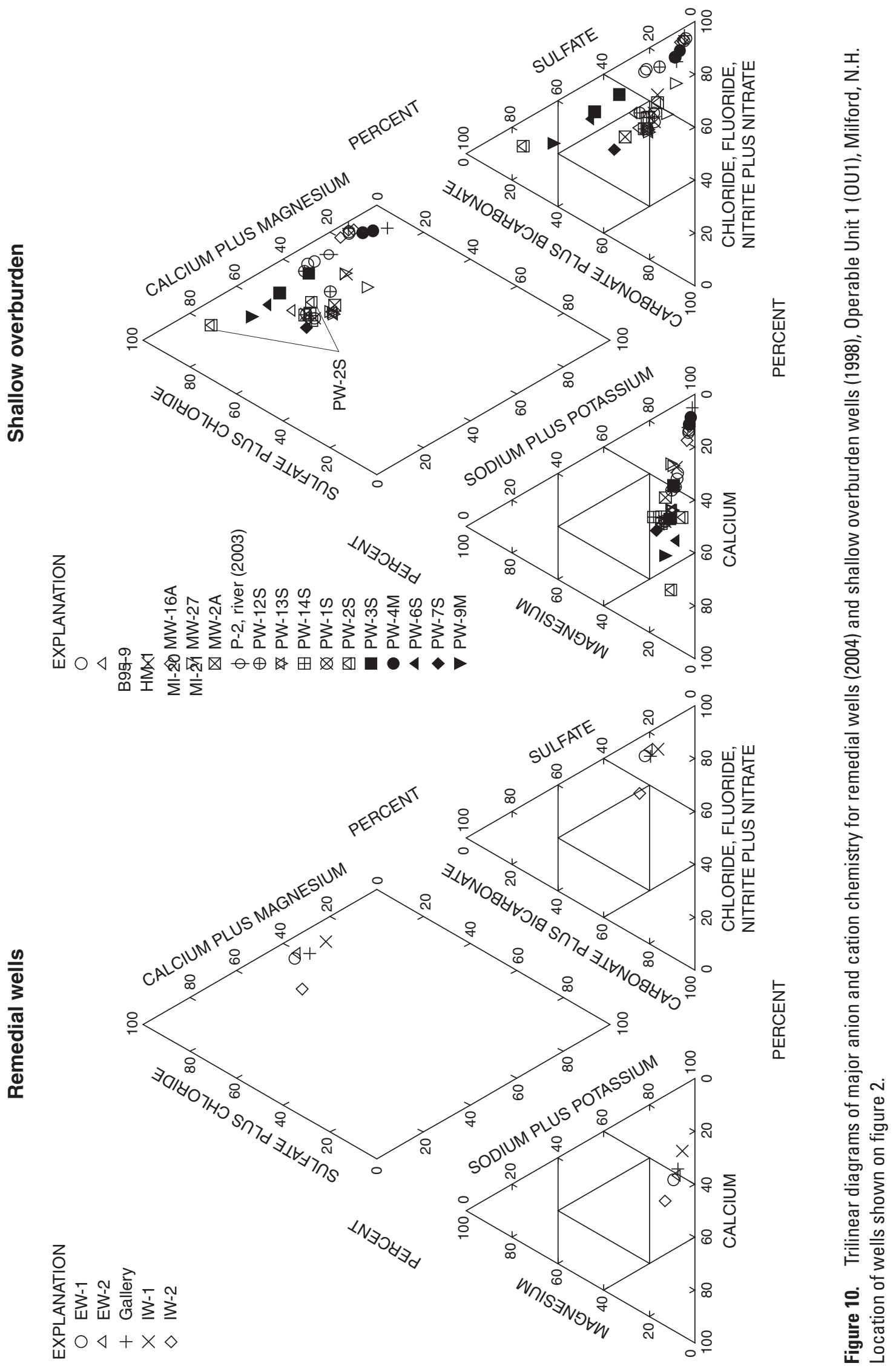


음

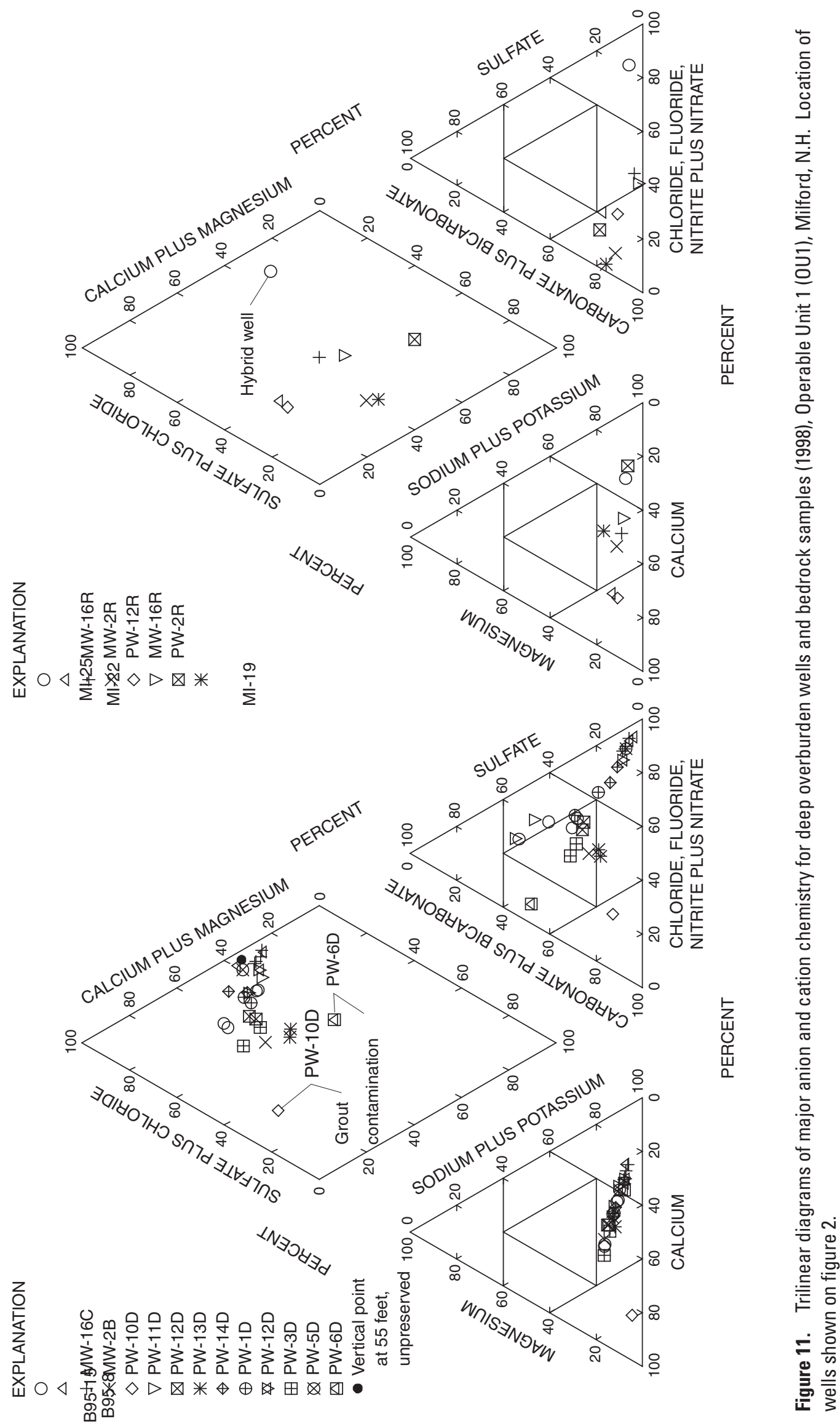


overburden wells contain higher percentages of sodium and chloride than remedial wells, while others (PW-2S) contain some higher calcium concentrations (relative to other cation concentrations) and could be affected by slurry from the barrier.

Bedrock water chemistry has the highest percentage of bicarbonate concentrations to total anion concentrations, and bicarbonate concentrations from bedrock well samples (mean concentration of $65 \mathrm{mg} / \mathrm{L}$ ) exceed bicarbonate concentrations of samples from remedial and overburden wells. Differences in the vertical distribution of bicarbonate concentrations between overburden and bedrock are useful to help quantify the amount of bedrock water being captured by extraction of remedial wells.

Bicarbonate concentrations of interior wells IW-1 $(23 \mathrm{mg} / \mathrm{L})$ and IW-2 $(22 \mathrm{mg} / \mathrm{L})$ exceed concentrations of exterior wells EW-2 (14 mg/L) and EW-1 (12 mg/L) and indicate interior wells capture more bedrock waters than the exterior wells. Bicarbonate concentrations are highest in bedrock waters (mean concentration of $65 \mathrm{mg} / \mathrm{L}$ ), whereas bicarbonate concentrations of samples from overburden wells are low (mean concentration of $13.2 \mathrm{mg} / \mathrm{L}$ and $14.6 \mathrm{mg} / \mathrm{L}$ for shallow and deep overburden, respectively). The bicarbonate concentrations of the exterior remedial wells are similar to shallow and deep overburden wells and indicate negligible recharge from bedrock waters to the exterior wells (table 2). The bicarbonate concentrations of the interior remedial wells are higher than that of the shallow and deep overburden wells and indicate some recharge from bedrock waters to the internal wells. By use of a mass-balance equation to solve for two sources (bedrock and deep overburden) of water to the interior wells, and solving for the bicarbonate concentration of $23 \mathrm{mg} / \mathrm{L}$ (IW-1), a percent contribution of bedrock recharge to IW-1 of 17 percent is computed. This number is probably a minimum value of bedrock recharge because as bedrock water upflows into the interior barrier area and travels in the deep overburden to the IW-1 well, some bicarbonate reaction to carbonic acid probably takes place given the lower $\mathrm{pH}$ of ground water in the overburden, which would tend to reduce bicarbonate concentrations en route to the well.

\section{Volatile Organic Compound Trends}

The distribution of PCE concentrations in the middle overburden from 1995 is shown in figure 2. Concentrations in the middle overburden typically rank between the shallow (low concentrations) and deep (high concentrations) overburden except near source areas. The area containing concentrations at or above $1,000 \mathrm{ppb}$ is extensive and continuous from the suspected source zones; source zones are shown on figure 2. In December 1998, PCE concentrations were similar to 1995 as shown in figure 12. In December 1998, the barrier was just completed but remedial extraction had yet to start.

Pre-remedial VOC trends were examined in Harte (2004) who showed that a first-order exponential decay equation could describe bulk decreases of VOC concentrations in OU1.
An exponential rate constant of 0.13 was computed (Harte, 2004 , p. 14). Given a rate constant of 0.13 , for the 3 years between 1995 and 1998, a reduction of PCE concentrations of less than a third would occur, which is supported by the similarity in concentrations shown on figure 12 and figure 2 . The reductions in VOCs are probably from a decrease in the amount of dissolution from the DNAPL as a result of a mass decrease in the DNAPL pool size.

In November 2001 (fig. 13), remedial operation of the extraction wells, partial operation of the SVE wells inside the barrier, and containment by the barrier help reduce and limit transport of PCE as indicated by the reduction in size of the area covered by the 1,000 ppb contour. In November 2001, the $1,000 \mathrm{ppb}$ contour terminates at the barrier wall unlike in 1998 (fig. 12) when it extends into OU2. Remedial rates of PCE decrease were shown by Harte (2004) to increase from an exponential rate constant of 0.13 to 0.26 . For the 3 -year period from 1998 to 2001, a reduction of PCE concentrations of more than 50 percent would occur, as supported by the reduction in area covered by the $1,000 \mathrm{ppb}$ contour (figs. 12-13).

In November 2000, chlorinated solvents were accidentally released to the recharge gallery because of a problem with the treatment system (U.S. Environmental Protection Agency, 2001). The exact mass of VOCs released is unknown but estimated PCE concentrations ranged from 13,000 to 260,000 ppb. PCE concentrations increased in adjacent shallow and medium wells (PW-12S and PW-12M) in the spring of 2001 (Leah Desmarais, New Hampshire Department of Environmental Services, written commun., 2004). In June 2001, exploratory vertical profiles were installed to help map the release (Camp, Dresser, and McKee, Inc., 2001). A revised November 2001 PCE concentration map (fig. 14) with the incorporated vertical profile data (appendix 2) shows a distinct PCE plume expanding from the recharge gallery in the deep overburden (fig. 14C).

Comparison of PCE concentration over time to initial PCE concentration at the start of remediation in December 1998 allows for identification of areas where PCE decreases are static or show little change. Concentrations from April 2004 indicate that most exterior barrier wells had concentrations about one-fifth of the initial concentrations (table 3). Well samples with slow or negligible decreases include PW-14M in the middle overburden and PW-2R in the bedrock. PW-14M is located downgradient from the EW-1 and EW-2 wells and ground-water velocities are slowed from extraction. Bedrock well PW-2R is just outside of the barrier and remedial extraction inside the barrier probably decreases dilution in the bedrock because of induced bedrock upflow into the overburden.

Decreases in PCE concentration show large variability in interior wells. Wells east of interior extraction wells IW-1 and IW-2 and away from the direct path of suspected source zones and extraction wells show large decreases (table 4 and fig. 2). Wells located between source zones and interior extraction wells show no decrease. PW-6 cluster wells generally show large increases (PW-6D, table 4). This indicates that the 


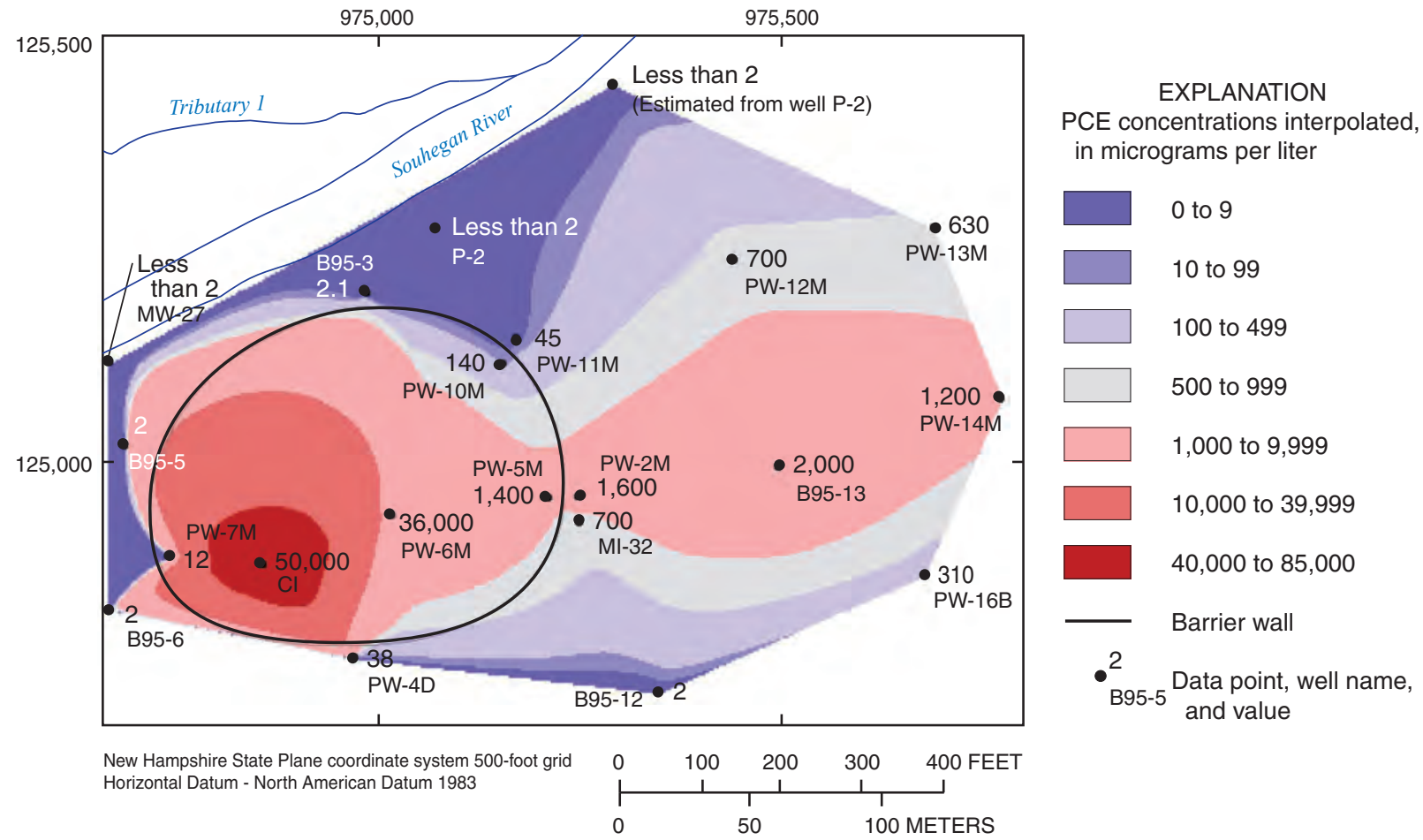

Figure 12. Concentrations of tetrachloroethylene (PCE) in middle overburden, December 1998, Operable Unit 1 (OU1), Milford, N.H.

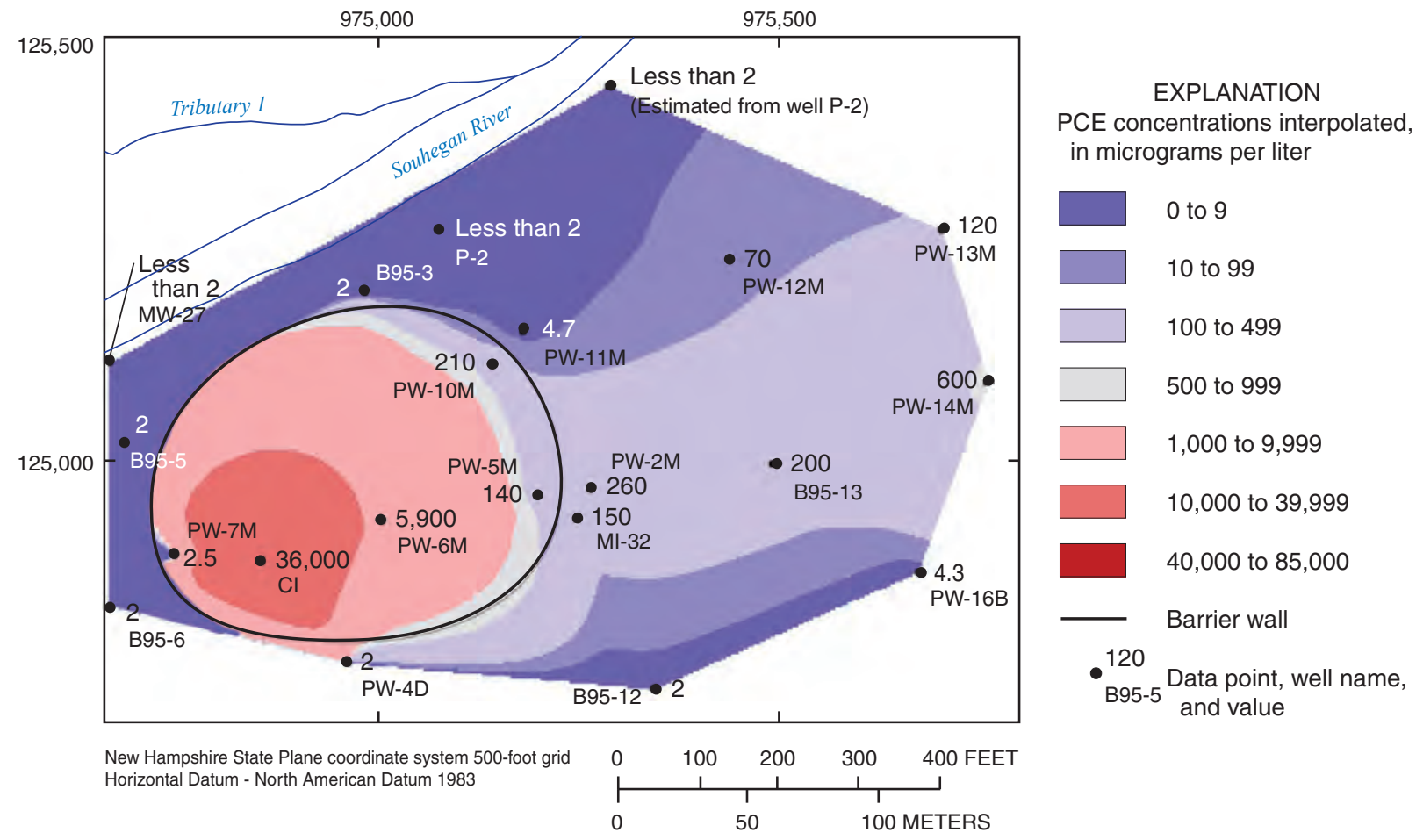

Figure 13. Concentrations of tetrachloroethylene (PCE) in middle overburden, November 2001, Operable Unit 1 (OU1), Milford, N.H. 
A. Shallow overburden from shallow-depth samples, 0 to 40 feet deep

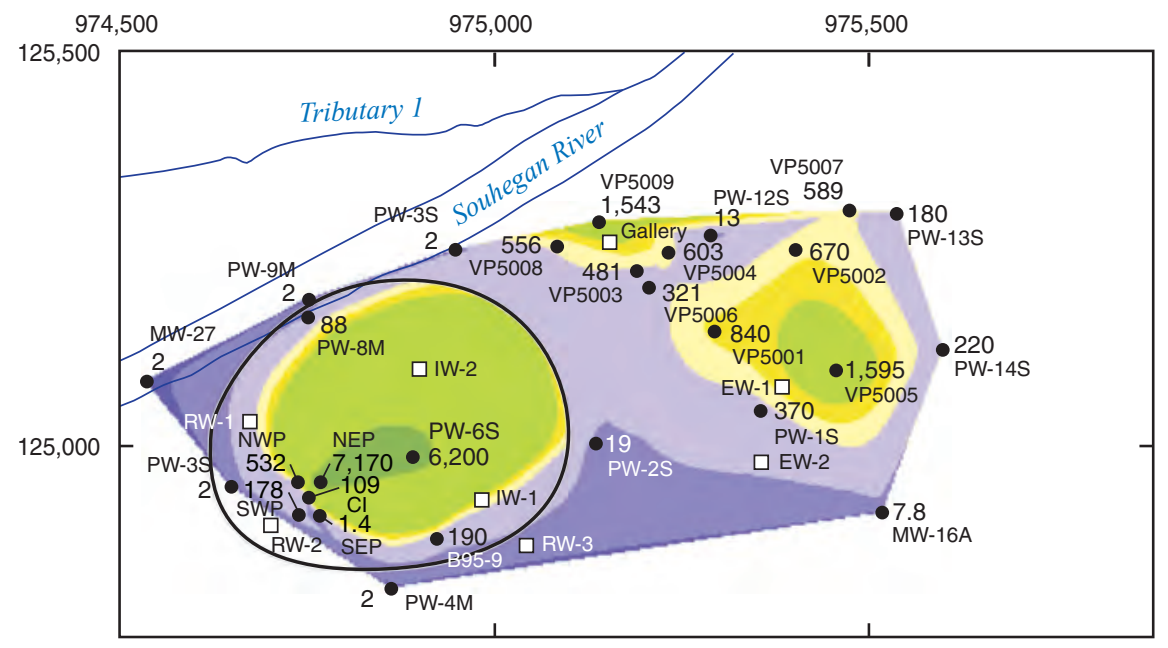

New Hampshire State Plane coordinate system 500 -foot grid

B. Middle overburden from medium-depth samples, 40 to 70 feet deep

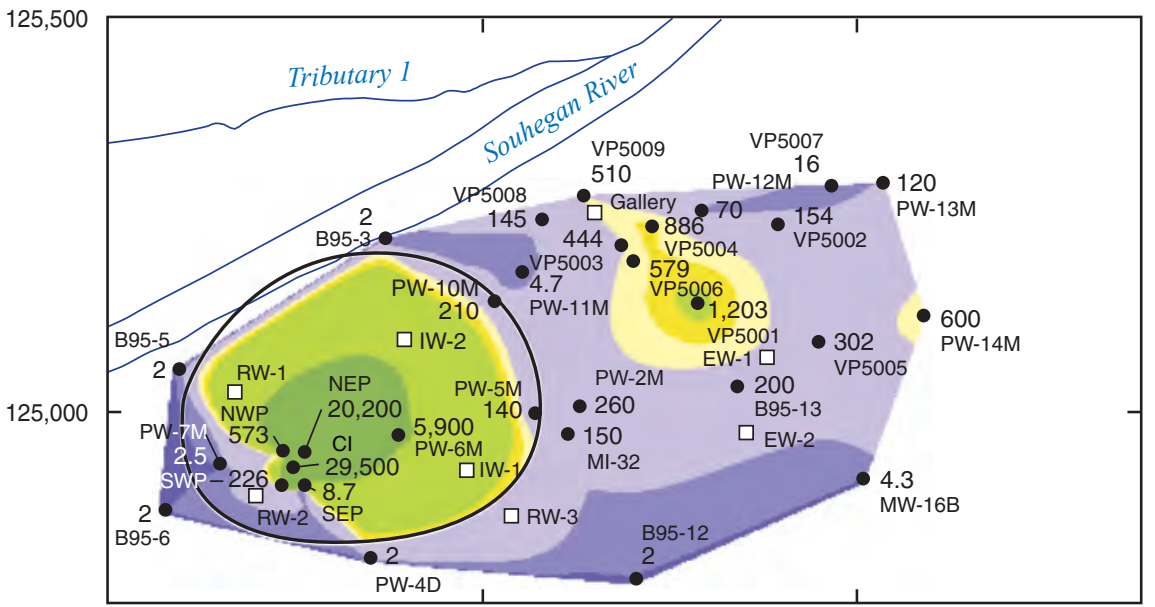

C. Deep overburden from deep samples, 70 to 105 feet deep

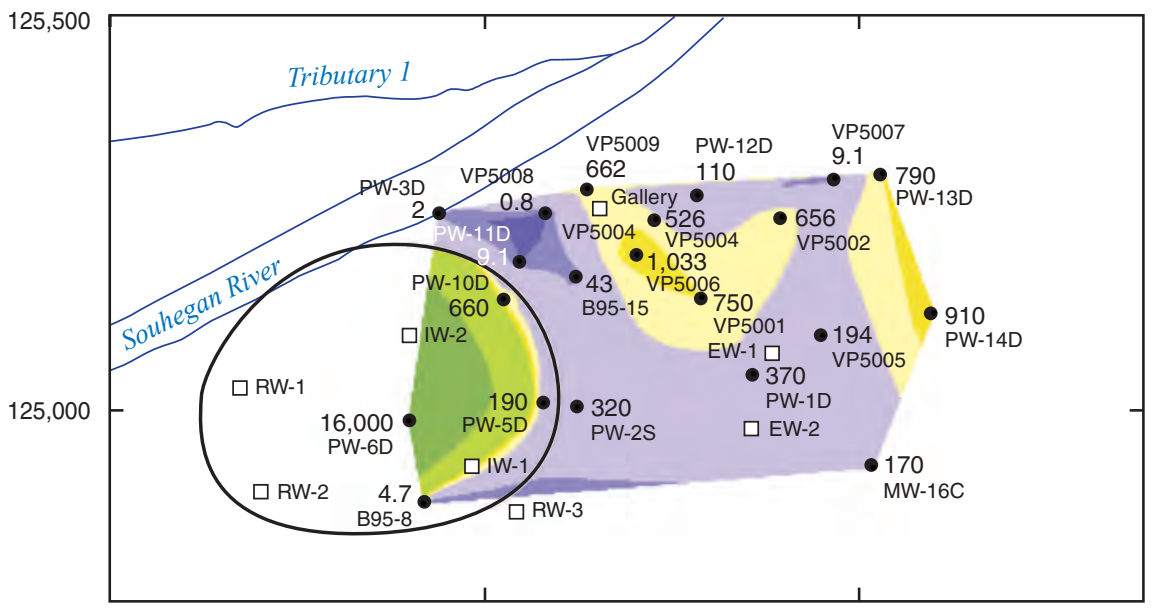

\section{EXPLANATION}

PCE concentrations interpolated, in micrograms per liter

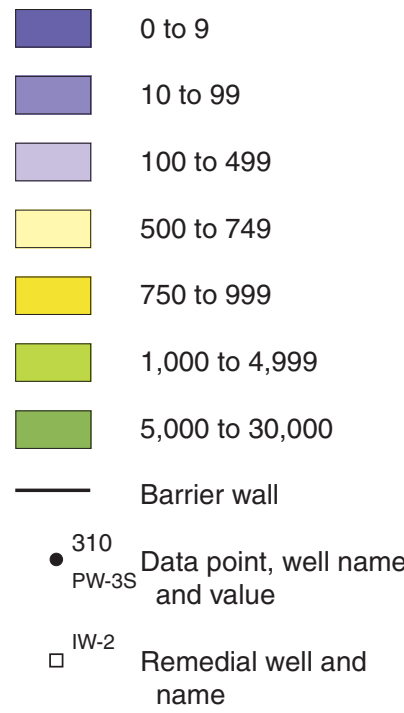

Figure 14. Maximum concentrations of tetrachloroethylene (PCE) in November 2001 for $A$, shallow, $B$, middle, and $C$, deep overburden, Operable Unit 1 (OU1), Milford, N.H. 


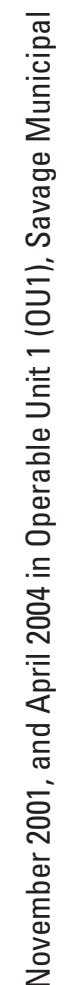

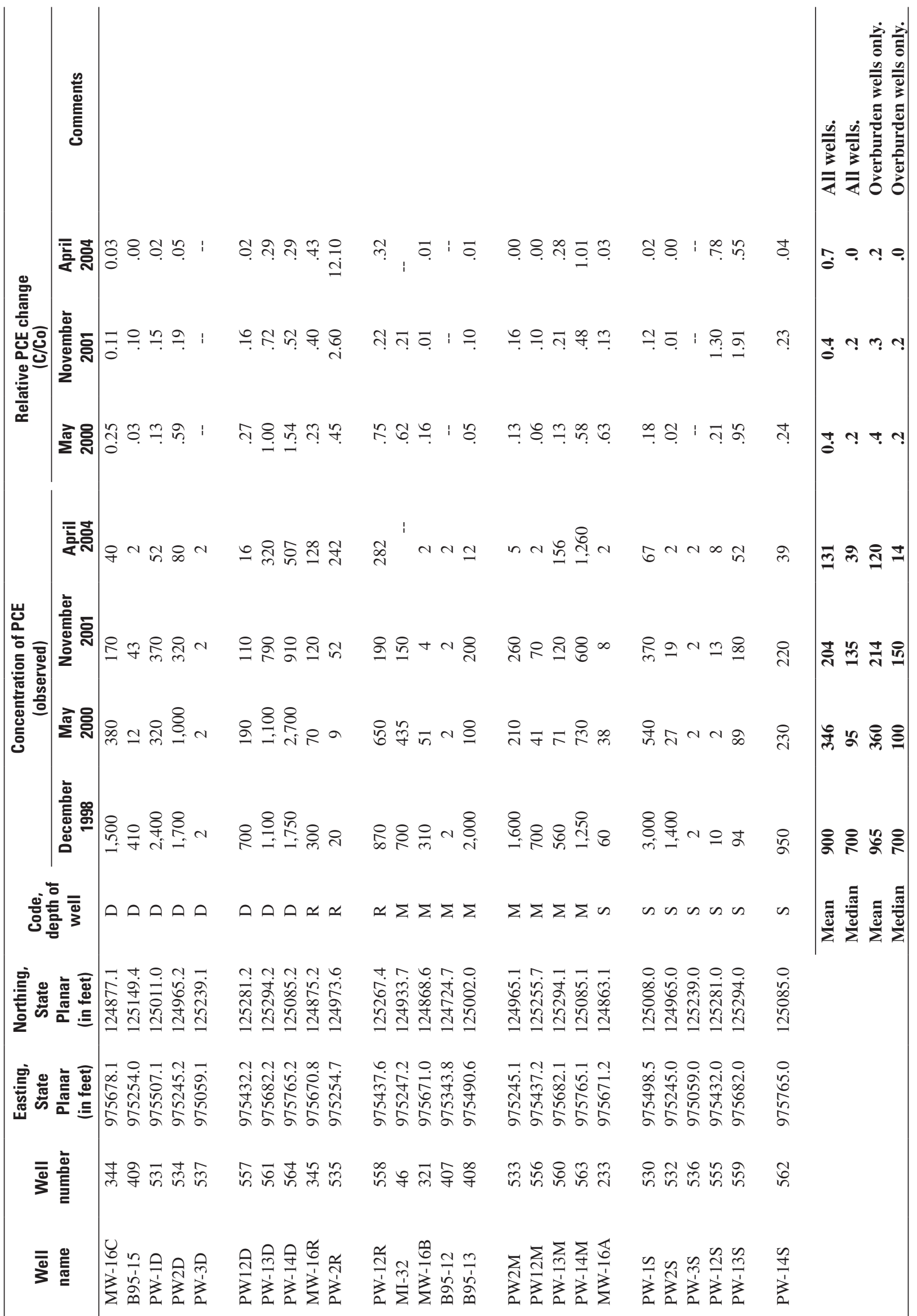


Table 4. Observed PCE concentrations of interior barrier wells for December 1998, May 2000, November 2001, and April 2004 in Operable Unit 1 (OU1), Savage Municipal Well Superfund site, Milford, N.H.

[PCE, tetracholorethylene; $\mathrm{C} / \mathrm{Co}$, ratio of current to initial concentration; concentrations in parts per billion (ppb); wells sorted by depth: S, shallow (less than 40.1 feet midpoint depth of screen below land surface); M, medium (40.1-70 feet depth); D, deep (greater than 70 feet); R, bedrock; well locations shown on figure 2]

\begin{tabular}{|c|c|c|c|c|c|c|c|c|c|c|c|}
\hline \multirow{2}{*}{$\begin{array}{l}\text { Well } \\
\text { name }\end{array}$} & \multirow{2}{*}{$\begin{array}{c}\text { Well } \\
\text { number }\end{array}$} & \multirow{2}{*}{$\begin{array}{l}\text { Easting, } \\
\text { State } \\
\text { Planar } \\
\text { (in feet) }\end{array}$} & \multirow{2}{*}{$\begin{array}{c}\text { Northing, } \\
\text { State } \\
\text { Planar } \\
\text { (in feet) }\end{array}$} & \multirow{2}{*}{$\begin{array}{c}\text { Code, } \\
\text { depth of } \\
\text { well }\end{array}$} & \multicolumn{4}{|c|}{$\begin{array}{c}\text { Concentration of PCE } \\
\text { (observed) }\end{array}$} & \multicolumn{3}{|c|}{$\begin{array}{l}\text { Relative PCE change } \\
\text { (C/Co) }\end{array}$} \\
\hline & & & & & $\begin{array}{c}\text { December } \\
1998\end{array}$ & $\begin{array}{l}\text { May } \\
2000\end{array}$ & $\begin{array}{c}\text { November } \\
2001\end{array}$ & $\begin{array}{l}\text { April } \\
2004\end{array}$ & $\begin{array}{l}\text { May } \\
2000\end{array}$ & $\begin{array}{c}\text { November } \\
2001\end{array}$ & $\begin{array}{l}\text { April } \\
2004\end{array}$ \\
\hline B95-8 & 403 & 975035.4 & 124825.8 & $\mathrm{D}$ & 65 & 10 & 5 & 2 & 0.15 & 0.07 & 0.03 \\
\hline PW-5D & 541 & 975206.8 & 124969.2 & $\mathrm{D}$ & 1,500 & 420 & 190 & 57 & .28 & .13 & .04 \\
\hline PW-6D & 545 & 975014.3 & 124943.8 & $\mathrm{D}$ & 610 & 11,000 & 16,000 & 18,400 & 18.03 & 26.23 & 30.16 \\
\hline PW-5M & 540 & 975198.9 & 124963.3 & M & 1,400 & 690 & 140 & 17 & .49 & .10 & .01 \\
\hline PW-6M & 544 & 975005.4 & 124932.2 & M & 3,600 & 3,100 & 5,900 & 4,780 & .86 & 1.64 & 1.33 \\
\hline PW-7M & 548 & 974748.6 & 124890.1 & M & 12 & 2 & 3 & 2 & .20 & .21 & .17 \\
\hline PW-10M & 551 & 975142.3 & 125124.8 & M & 140 & 180 & 210 & 112 & 1.29 & 1.50 & .80 \\
\hline B95-9 & 404 & 975039.8 & 124825.6 & $\mathrm{~S}$ & 610 & 230 & 190 & 158 & .38 & .31 & .26 \\
\hline PW-6S & 543 & 975004.8 & 124942.1 & $\mathrm{~S}$ & 3,100 & 4,600 & 6,200 & 3,000 & 1.48 & 2.00 & .97 \\
\hline \multirow[t]{3}{*}{ PW-7S } & 547 & 974747.6 & 124900.1 & $\mathrm{~S}$ & 40 & 2 & 2 & 2 & .06 & .05 & .05 \\
\hline & & & & Mean & 1,416 & 1,715 & 2,297 & 2,133 & 1.9 & 2.5 & 2.7 \\
\hline & & & & Median & 610 & 230 & 190 & 112 & .4 & .3 & .3 \\
\hline
\end{tabular}

DNAPL source has not been effectively remediated and that less dilution occurs inside the barrier than originally estimated for pre-remedial conditions. As a result, NHDES and USEPA have instituted aggressive treatment at this location as discussed in the section titled "Previous Investigations of Contaminant Source and Remediation."

Secondary VOC concentrations followed trends in PCE concentrations (figs. 15-16) inside and outside the barrier from 1998 to 2004. Concentrations of secondary VOCs (TCE, and $c i s-1,2 \mathrm{DCE}$ ) are typically one-tenth to one-fifth the concentrations of PCE. Several interesting results are visible in the graphs in figures 15 and 16. First, a spike in PCE concentration occurs in January 2001 at PW-12S (fig. 15) that corresponds to the release in the fall of 2000 from the gallery. This spike in PCE concentration is not associated with a corresponding spike in secondary VOC concentrations. VOC concentrations from vertical profile points in 1995 compared to points collected in June 2001 indicate that PCE concentration comprised 99 percent of the total VOC concentration in 2001, whereas in 1995, it was 92 percent. Second, large decreases in PCE and secondary VOC concentrations are observed in overburden wells outside the barrier (fig. 15, PW-12S, 12M, and 12D) but not in overburden wells inside the barrier (fig. 16, PW-6S, 6M, and 6D). Third, only small decreases in PCE and secondary VOC concentrations are detectable in the bedrock well outside of the barrier (fig. 15, PW-12R).

\section{Effects of Barrier Construction and Trench Depths on Lateral Inflow}

Examination of barrier wall construction and trench depths is useful to assess the amount of lateral inflow in the overburden between the interior and exterior barrier areas. Quantification of lateral inflow rates contribute to the development of water budgets for the interior overburden area. The interior water budget is then used to help develop conceptual models of flow to the interior extraction wells.

The barrier was constructed from June to November 1998. During construction, trench depths were recorded (appendix 3) and confirmed depths to bedrock and till contacts were noted. The coordinate system used to identify barrier and trench locations is given in figure 17. The barrier was designed and installed to fully penetrate the sand and gravel units of the overburden, and in most places, the basal till so as to sit atop bedrock. Where hard refusal or till was encountered, the barrier was set at least $3 \mathrm{ft}$ into it (Richard Goehlert, U.S. Environmental Protection Agency, oral commun., 1999). 

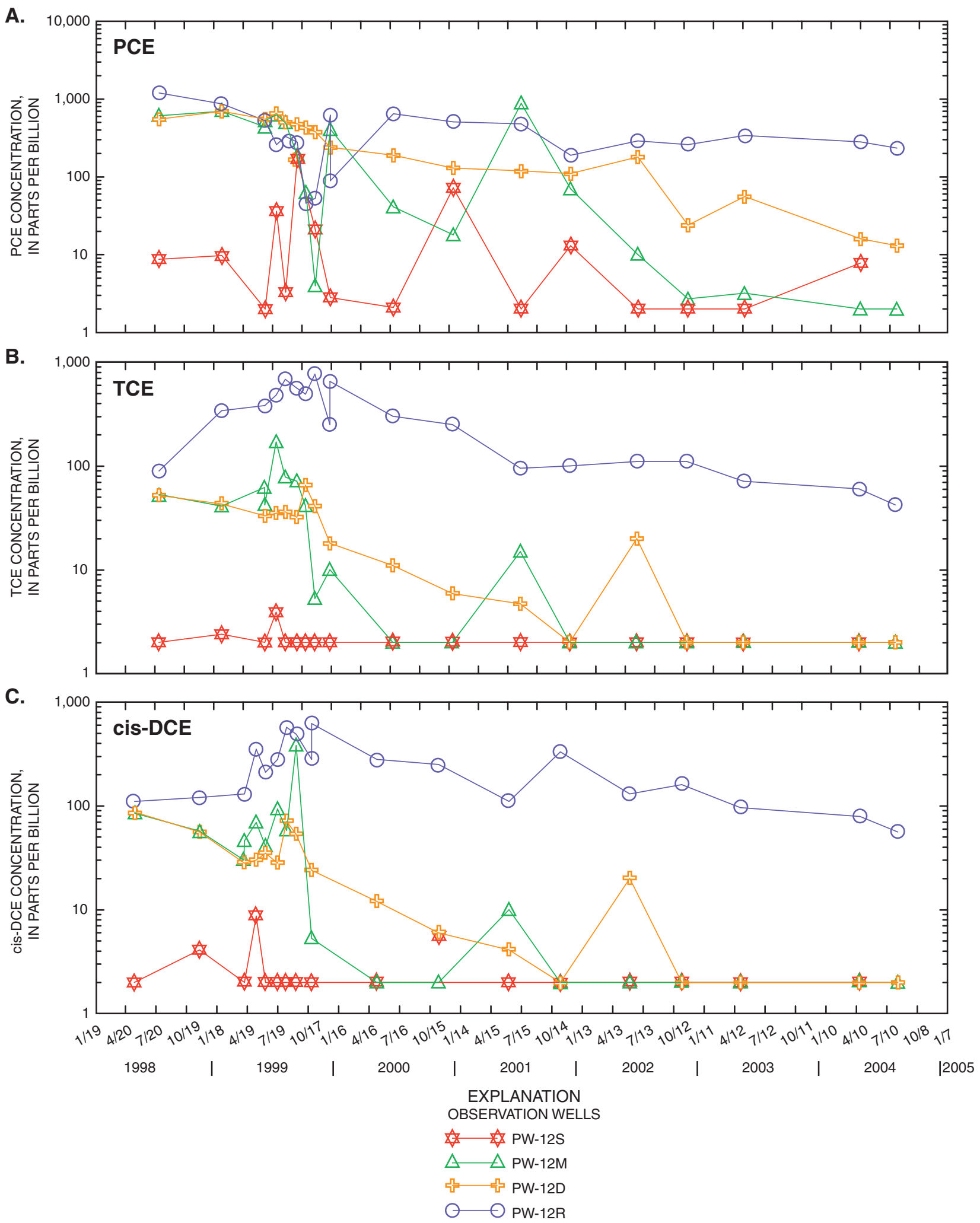

Figure 15. Concentrations of $A$, tetrachloroethylene (PCE), $B$, trichloroethylene (TCE), and $C$, cis-1,2 dichloroethylene (cisDCE) for PW-12 cluster wells, Operable Unit 1 (OU1), Milford, N.H., 1998-2004. Location of wells shown on figure 2. 


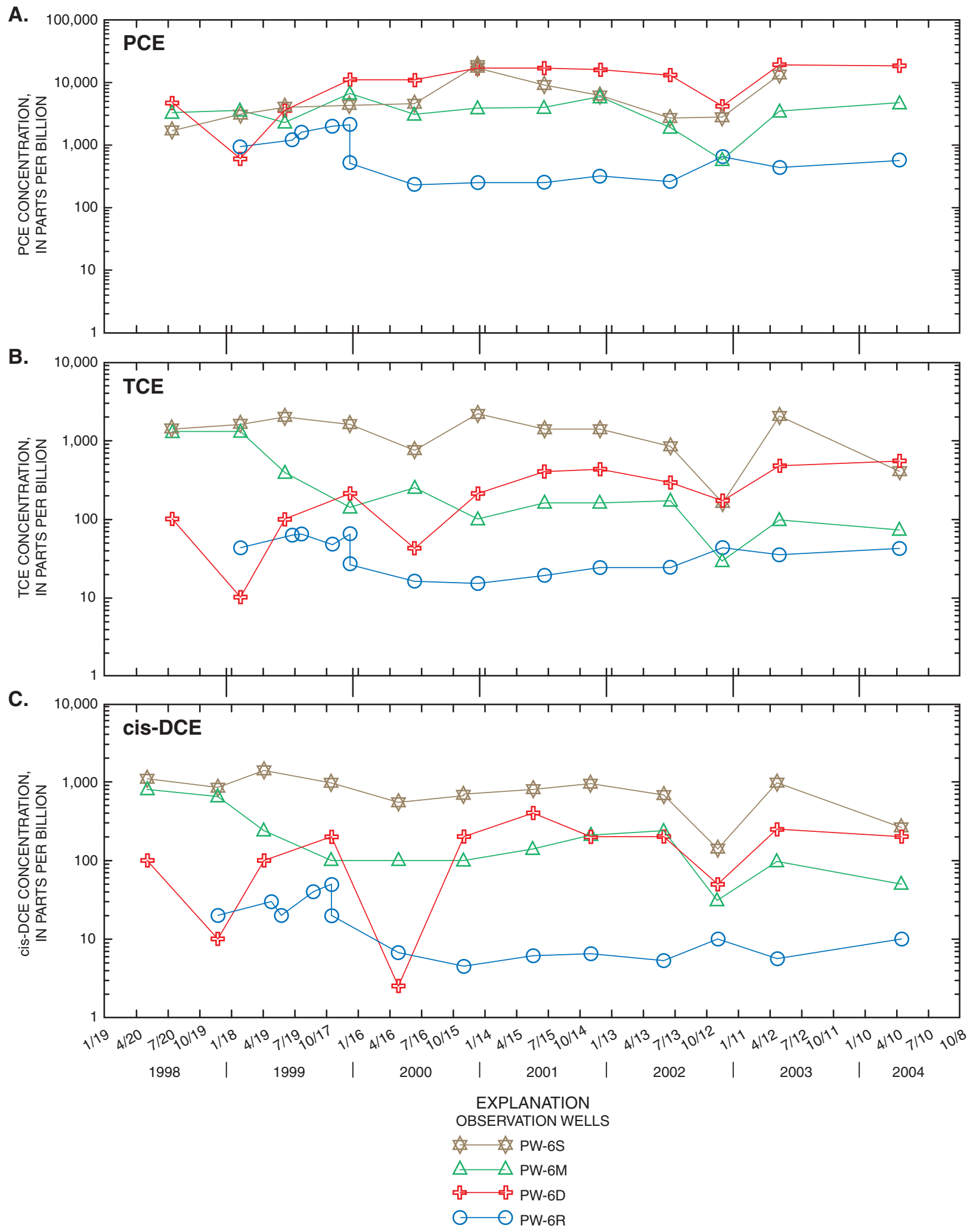

Figure 16. Concentrations of $A$, tetrachloroethylene (PCE), $B$, trichloroethylene (TCE), and $C$, cis-1,2 dichloroethylene (cisDCE) for PW-6 cluster wells, Operable Unit (OU1), Milford, N.H., 1998-2004. Location of wells shown on figure 2. 


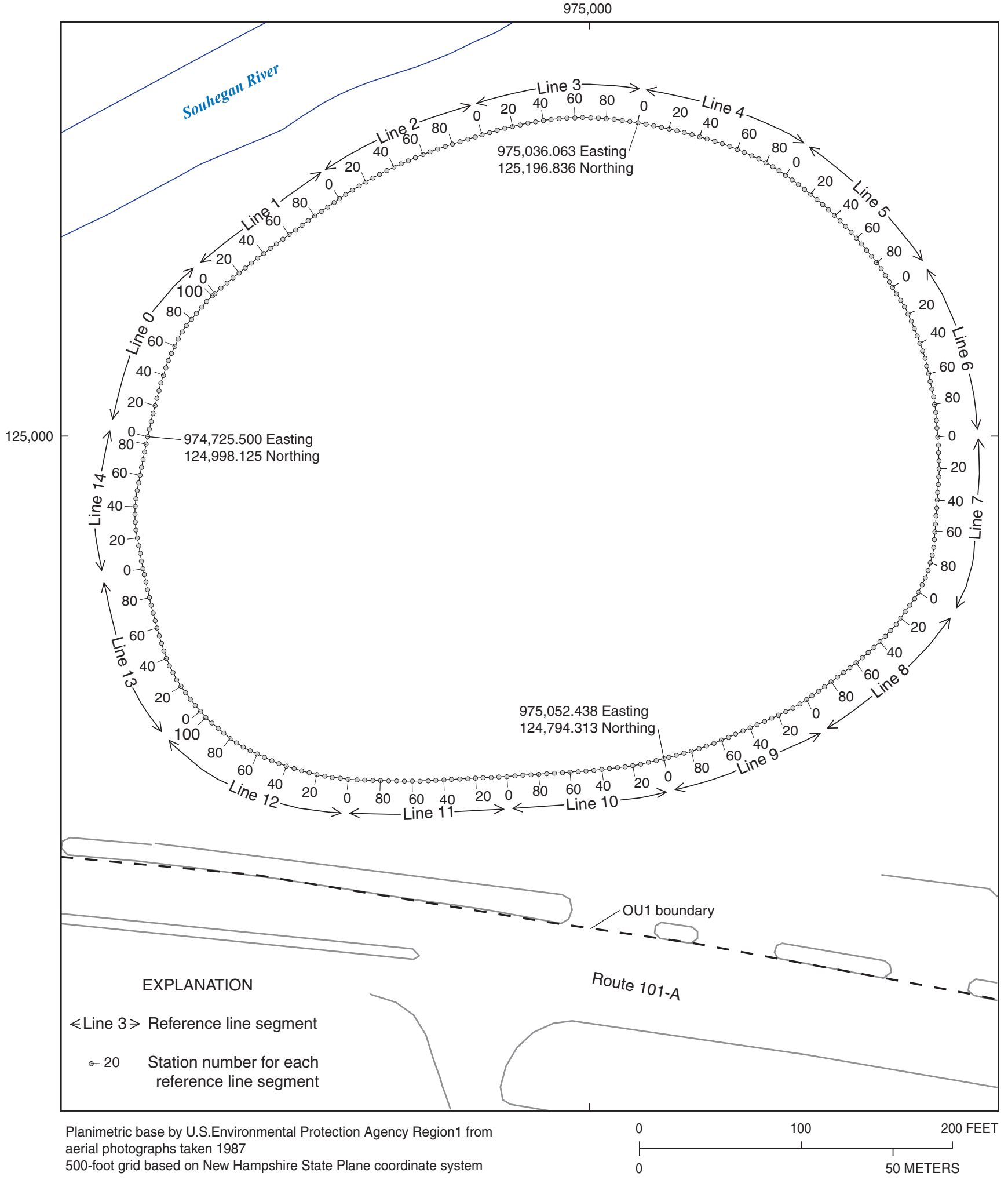

Figure 17. Location, reference lines, and station numbers for completed (as built) barrier-trench system, Operable Unit 1 (OU1), Milford, N.H. 
Recorded trench depths from barrier construction were compared to interpolated bedrock surface depths that were generated from borehole logs. The interpolated bedrock surface was from a previously used ground-water-flow and solute-transport model by Harte (2004). The comparison helps identify areas where premature trench depths may occur because incomplete penetration into the overburden would allow lateral flow of water in the overburden under the barrier.

Most of the barrier trench depths (called "as built" depths) match the interpolated bedrock surface and small differences of less than $5 \mathrm{ft}$ (the assumed reasonable match criteria) occur. In other areas where trench depths are more than $5 \mathrm{ft}$ shallower than the interpolated surface, confirmed bedrock was noted during construction, which indicates that the interpolated surface is too deep. In a small area near lines 12 (fig. 17) and 5, trench depths exceeded the interpolated bedrock surface by more than $5 \mathrm{ft}$ indicating the interpolated surface is too shallow.

Trench depths along one area of the barrier were identified as potentially being too shallow (by more than $5 \mathrm{ft}$ ), which can allow horizontal flow into the overburden under the barrier. This area is from line 13 station 50 to line 0 station 50 . Given the subsurface lithology at that location and reported trench depths, it is surmised that potentially up to $10 \mathrm{ft}$ of till is not penetrated by the barrier.

No appreciable (greater than $5 \mathrm{ft}$ thick) layers of sand and gravel were identified as incompletely (not fully) penetrated by the barrier. This indicates that horizontal ground-water flow in the overburden under the barrier area is small because incomplete penetration was only identified in the till. A calculation of one-dimensional ground-water flow using a Darcyflow equation was done and a potential inflow of $0.7 \mathrm{gal} / \mathrm{min}$ was computed for the identified incomplete penetration area in the till. A flow rate of $0.7 \mathrm{gal} / \mathrm{min}$ was calculated assuming a horizontal hydraulic conductivity of $5 \mathrm{ft} / \mathrm{d}$ for the till, an average thickness of $10 \mathrm{ft}$, a length of $100 \mathrm{ft}$, and a horizontal gradient of $0.033 \mathrm{ft} / \mathrm{ft}$ for that area of the barrier. Harte (2004) found that bedrock upflow is likely to be a much more important component of the interior water budget (about 10 times greater in magnitude) than the estimated rate of lateral inflow through the till.

Thin (thickness less than $5 \mathrm{ft}$ ) permeable layers that are not fully penetrated by the barrier (permeable windows) are potentially unidentifiable. The likelihood of these layers existing is probably greatest in areas where the permeable layer directly overlies the bedrock in areas without till. Such areas may occur along the eastern perimeter of the barrier; however, data resolution is high in these areas and currently (2004), no permeable windows have been identified.

\section{Simulation of the Remedial System and its Operation}

Ground-water simulations of the remedial injection/ extraction system were done to (1) understand sources of water and the water budget to extraction wells, (2) evaluate effectiveness of injection/extraction system to capture contaminated ground water within the overburden, (3) examine the relative importance of flow processes on capture of contaminated ground water, and (4) evaluate effectiveness of containment of the low-permeability barrier. A numerical ground-water flow and solute transport model was used to simulate the remedial ground-water system. Only the results of the flow simulations are presented in this report. A detailed description of the flow and transport model used for this study is presented in Harte (2004). The model consists of five layers approximately vertically discretized into 20 -ft-thick model layers with horizontal discretization approximately 25 by $50 \mathrm{ft}$ in OU1 (appendix 4). Model layers 1 and part of 2 correspond to the shallow overburden, layer 3 corresponds primarily to the medium overburden, and layers 4 and 5 correspond to the deep overburden.

For this report, most of the model simulations were done with a steady-state version of the remedial-transport model (Harte, 2004, p. 34). This steady-state model uses average rates of recharge and river stage as reported in Harte (2004, p. 25) but varies withdrawals based on simulated remedial operations. Hydraulic properties and other model-input values used in this report were the same as those presented in Harte (2004) unless otherwise noted. Simulations used the computer code MODFLOW-2000 (Harbaugh and others, 2000) and included tracking of advective transport of ground-water flow with ground-water particles to discern flow direction, velocity, and capture areas by use of MODPATH (Pollack, 1994).

The transient and steady-state remediation model used the MODFLOW Horizontal-Flow Barrier Package (HFB) (Hsieh and Freckleton, 1993) to simulate the barrier. The wall was set at a hydraulic conductivity value of $1.64 \mathrm{e}-09 \mathrm{ft} / \mathrm{s}$ based on permeability tests of the barrier slurry (Camp, Dresser, and McKee, Inc., written commun., 1998). The barrier-wall thickness is $3 \mathrm{ft}$ and extends from above the water table to the bedrock or $3 \mathrm{ft}$ into the till. A computer program ARGUS MODFLOW GUI (Winston, 2000) was used to assign barrierwall hydraulic properties.

An important component of the remediation model is the solution of the interior area ground-water-flow budget for inside the barrier. The ground-water budget for inside the barrier wall is summarized as follows:

Net extraction $=$ direct recharge \pm net storage \pm net flow through the barrier \pm net flow under the barrier \pm bedrock upflow

The net extraction term is controlled by the amount of extraction at IW-1 and IW-2 minus any injection at RW-1 and RW-2. 
Information on net extraction rates from 1999-2003 is listed in table 5 .

The transient-remedial model solves for the right-hand side of equation 1 . The steady-state model version assumes that net storage changes are negligible. Harte (2004) found that annual storage changes are likely less than $1.2 \mathrm{gal} / \mathrm{min}$ or less than 10 percent of the 1999 annual ground-water budget for the interior barrier area.

Direct recharge inside the barrier from infiltration of precipitation was estimated at a yearly rate of $1.75 \mathrm{gal} / \mathrm{min}$ (Brayton and Harte, 2001). This rate is 50 percent less than the rate for outside the barrier. Brayton and Harte (2001) found that recharge rates inside the barrier area decreased by as much as a half from pre-construction periods because of the addition of a semiconical land-surface crown during barrier construction. Analysis of additional data subsequent to that reported in Brayton and Harte (2001) indicates that a recharge rate of $2.45 \mathrm{gal} / \mathrm{min}$ also may be appropriate (about a 30-percent reduction from outside the barrier). Therefore, simulated ranges in direct recharge varied from 1.75 to $2.45 \mathrm{gal} / \mathrm{min}$.

The amount of inflow and outflow either through (throughflow) or under (underflow) the barrier in the overburden is considered a small part of the water budget for the interior barrier area. The barrier hydraulic conductivity $(1.64 \mathrm{e}-9 \mathrm{ft} / \mathrm{s})$ is low (Harte, 2004); therefore, the maximum inflow through the barrier is small. Furthermore, the analysis of trench depths indicates that only a small area in the till may not be penetrated by the barrier. An inflow rate from underflow into the interior barrier area (containment area) of $0.7 \mathrm{gal} / \mathrm{min}$ was calculated. Simulated ranges for underflow and throughflow are solved in the model but are constrained by the depth of penetration of the barrier assumed in the model.

Examination of the ground-water budget (eq. 1) for the interior barrier area shows that most of the annual budget is likely derived from bedrock upflow. In 1999, for the minimum rate of net extraction $(9.6 \mathrm{gal} / \mathrm{min})$ and assuming no storage changes, bedrock upflow is at least 57 percent ( $5.45 \mathrm{gal} / \mathrm{min})$ of the interior ground-water budget, assuming inflow through or under the barrier of $1.7 \mathrm{gal} / \mathrm{min}$ and a recharge rate of $2.45 \mathrm{gal} / \mathrm{min}$, or at the most 82 percent of the budget $(7.85 \mathrm{gal} / \mathrm{min})$, assuming no inflow through or under the barrier and a recharge rate of $1.75 \mathrm{gal} / \mathrm{min}$. Simulated ranges in bedrock upflow, therefore, varied from 5.45 to $7.85 \mathrm{gal} / \mathrm{min}$ for 1999 conditions but increased, as discussed in the following paragraphs, for other conditions. Because bedrock upflow is calculated as a residual term in the groundwater budget for the interior barrier area, the accuracy of values calculated for bedrock upflow relies on the accuracy of the other calculated terms. Nevertheless, the importance of bedrock upflow in sustaining the net extraction rates inside the barrier is supported by water-budget calculations and by water-level monitoring.

To simulate upflow from the bedrock, a series of hypothetical injection wells were assigned to the model at the base of the overburden in layer 5 of the model because the bedrock is not simulated in the model and the bottom model boundary is treated as a no-flow boundary. Injection wells were simulated in areas where the till is thin or absent in the eastern half of the interior barrier area.

Initial model simulations assumed the barrier is fully penetrating with the barrier wall in the lowermost (5th) layer slightly more permeable (by a factor of 10) than the upper layers. This adjustment allows for some increased lateral inflow into the interior barrier area to account for the difficulty of constructing the barrier at the lowest depths of the overburden. Although the hydraulic conductivity of the barrier wall is increased by a factor of 10 in layer 5 , the barrier is still relatively impermeable and inflow into the interior barrier area is restricted. In this report, a primary modification to the simulations of the barrier is the depth of penetration in the overburden. To accommodate the increase in net extraction inside the barrier from 1999 to 2003, model-simulation scenarios included adjusting the depth of penetration of the

Table 5. Remedial wells and operational rates for selected wells 1999-2003, Operable Unit 1 (0U1), Savage Municipal Well Superfund site, Milford, N.H.

[All units in gallons per minute; rates represent mean rates while operating; *, combined mean rate; site type names explained in abbreviation section of report; location of all wells shown in figure 2; RW, injection well; IW, interior extraction well; EW, exterior extraction well; --, no data; Source of data: Camp, Dresser, and McKee, Inc., written commun. 2002; U.S. Filter, Inc. (2004 and 2005)]

\begin{tabular}{|c|c|c|c|c|c|c|c|c|c|}
\hline \multirow[b]{2}{*}{ Water year } & \multicolumn{4}{|c|}{ Inside barrier } & \multicolumn{4}{|c|}{ Outside barrier } & \multirow[b]{2}{*}{ Comments } \\
\hline & $\begin{array}{l}\text { Net extraction } \\
\text { rates }\end{array}$ & RW-1,2* & IW-1 & IW-2 & RW-3 & Gallery & EW-1 & EW-2 & \\
\hline 2000 & 28.9 & 0.0 & 13.5 & 15.4 & .0 & 62.6 & 14.5 & 15.5 & -- \\
\hline Early 2001 & 18.5 & .0 & 9.9 & 8.6 & .0 & 62.9 & 30.1 & 18.8 & Estimated rates. \\
\hline 2003 & 62.0 & .0 & 31.0 & 31.0 & 17.0 & 75.0 & 15.0 & 15.0 & Estimated rates. \\
\hline
\end{tabular}


barrier and the amount of ground-water upflow from the bedrock. An alternative approach to simulating increased net extraction would be to simulate increased barrier throughflow by specifying hypothetical permeable holes in the barrier.

This was not done because permeameter testing of the barrier bentonite material showed consistently low hydraulic conductivity values (range of 3.0e-9 to 3.0e-11; Camp, Dresser, and McKee, Inc., written commun., 1998).

\section{Effects of Operational Variations on Ground- Water Flow and Solute Transport}

This section includes a discussion on the effect of various remedial operational schemes, specifically, varying extraction and injection rates that were used, from 1999 to 2003 in OU1, on ground-water flow and solute transport. From 1999 to 2003, the net amount of water extracted inside the barrier (net extraction) increased in an attempt to decrease heads inside the barrier for the purpose of maintaining inward hydraulic gradients around the barrier and allowing the efficient use of the SVE wells; the SVE wells work most efficiently when water levels inside the barrier are less than $255 \mathrm{ft}$. Continuously monitored water levels from well B95-9 show that water levels generally did not decrease below $257 \mathrm{ft}$ (Harte, 2005), although the net extraction inside the barrier increased from 9.6 to $62 \mathrm{gal} / \mathrm{min}$ from 1999 to 2003 (table 5).

The steady-state simulations discussed in this report were run with different rates of extraction and injection, as observed in the field at wells IW-1, IW-2, RW-1, RW-2, and at the recharge gallery. Rates were initially kept constant (25 gal/min) at EW-1 and EW-2, located outside the barrier, to simplify the analysis.

To facilitate the analysis of flow through the barrier (throughflow), assigned rates of recharge and bedrock upflow were initially kept constant (table 6; simulation type-_Evaluation of maximum barrier throughflow"). In addition, the barrier was assumed initially to fully penetrate the overburden with no openings in the till or sand and gravel layers. There- fore under these scenarios, the model calculates the maximum potential horizontal inflow in the overburden through the lowpermeability barrier wall. Interior barrier area ground-water budget terms per simulation are summarized in table 6 .

Assuming a fully penetrating barrier wall, as the simulated net extraction inside the barrier increased from 9.6 (1999 rate) to $18.5 \mathrm{gal} / \mathrm{min}$ (early $2001 \mathrm{rate}$ ), model cells inside the barrier dewatered as a result of insufficient inflow. Therefore, the maximum potential inflow through the barrier is less than $9.52 \mathrm{gal} / \mathrm{min}$, which was determined by adding the throughflow value computed by the model of $0.62 \mathrm{gal} / \mathrm{min}$ for the 1999 net extraction rate to the additional $8.9 \mathrm{gal} / \mathrm{min}$ (18.5 minus 9.6) needed for the 2001 net extraction rate. The throughflow rate of $0.62 \mathrm{gal} / \mathrm{min}$ for 1999 net extraction is equal to the net extraction rate of $9.6 \mathrm{gal} / \mathrm{min}$ minus an assigned bedrock upflow rate of $7.23 \mathrm{gal} / \mathrm{min}$ (calibrated value for 1999 conditions; Harte, 2004) and an assigned recharge rate of $1.75 \mathrm{gal} / \mathrm{min}$ (calibrated value for 1999 conditions; Harte, 2004).

To accommodate the increased net extraction rate while comparing to observed heads, it was necessary to simulate either incomplete penetration of the barrier or increase rates of bedrock upflow. The following discussion describes simulation results for the various rates (1999, 2001, 2002, and 2003) of net extraction after either adjusting the (1) depth of barrier penetration or (2) increasing assigned rates of ground-water upflow from the bedrock.

\section{Sensitivity of Inside Barrier Area to Lateral Inflow}

One of the primary reasons in simulating the remedial system and operation was to evaluate sources of water and their effect on capture areas to interior extraction wells (IW-1 and IW-2). One source of water to interior extraction wells is lateral inflow from underflow (eq. 1; term "net flow under the barrier"). The effect of varying the amount of lateral inflow as a result of net extraction inside the barrier for an assigned

Table 6. Model ground-water budget terms evaluated during simulations of interior barrier area remedial system, Operable Unit 1 (OU1), Savage Municipal Well Superfund site, Milford, N.H.

[gal/min, gallons per minute; Codes used: F, fixed value during simulation; C, calculated in simulation; V, variable adjusted between simulations; values in parentheses represent simulated rates]

\begin{tabular}{l|ccccc}
\hline \multirow{2}{*}{ Simulation type } & \multicolumn{5}{c}{$\begin{array}{c}\text { Simulated ground-water budget terms } \\
\text { (All values in gal/min) }\end{array}$} \\
\cline { 2 - 7 } & $\begin{array}{c}\text { Net } \\
\text { extraction }\end{array}$ & $\begin{array}{c}\text { Direct } \\
\text { recharge }\end{array}$ & $\begin{array}{c}\text { Barrier } \\
\text { throughflow }\end{array}$ & $\begin{array}{c}\text { Barrier underflow } \\
\text { unflow }\end{array}$ & $\begin{array}{c}\text { Bedrock } \\
\text { upflow }\end{array}$ \\
\hline Evaluation of maximum barrier throughflow & $\mathrm{F}(9.6-18.5)$ & $\mathrm{F}(1.75)$ & $\mathrm{C}$ & $\mathrm{F}(0)$ & $\mathrm{F}(7.85)$ \\
Evaluation of barrier underflow & $\mathrm{F}(9.6-62.0)$ & $\mathrm{F}(1.75-2.45)$ & $\mathrm{C}$ & $\mathrm{C}$ & $\mathrm{F}(5.45-7.85)$ \\
\hline Evaluation of bedrock upflow & $\mathrm{F}(9.6-62.0)$ & $\mathrm{F}(1.75-2.45)$ & $\mathrm{C}$ & $\mathrm{F}(0)$ & $\mathrm{V}(7.85-58)$ \\
\hline
\end{tabular}


constant rate of assigned recharge and upflow from bedrock (eq. 1) is discussed in this section and shown in table 6 (simulation type-_Evaluation of barrier underflow"). To allow for increased rates of lateral inflow in the overburden into the interior barrier area, the hydraulic conductivity of barrier cells in the HFB package were increased to rates exceeding the aquifer (from $1.64 \mathrm{e}-9 \mathrm{ft} / \mathrm{s}$ or $1.4 \mathrm{e}-4 \mathrm{ft} / \mathrm{d}$ to $1.0 \mathrm{e}-1 \mathrm{ft} / \mathrm{s}$ or $8.6 \mathrm{e}+3 \mathrm{ft} / \mathrm{d}$ ). This procedure essentially assumes no barrier at these locations because it allows the horizontal hydraulic conductivity of the overburden, either the till $(5 \mathrm{ft} / \mathrm{d})$ or the sand and gravel $(60 \mathrm{ft} / \mathrm{d})$, to be the controlling factor of ground-water flow into the barrier.

Model results indicate it is unlikely that inflow into the interior barrier area is sufficient in the till if the barrier incompletely penetrates the till in small areas around the perimeter because interior model cells dewatered (excessive drawdown) with increased net extraction associated with 2001 conditions. In contrast, field-observation data indicate small (less than $6 \mathrm{ft}$ ) drawdowns. Initially, the hydraulic conductivity of the barrier was increased for one cell set in the till in layer 5, 50by-10-ft along the southern barrier by the PW-4 well cluster (fig. 2). In this scenario, model cells also dewatered inside the barrier. Two additional barrier cells in layer 5 (all in the till) were then increased. In this scenario, heads inside the barrier dewatered in layer 1 only, and model-computed heads were about $248 \mathrm{ft}$ at well B95-9. Because model-computed heads were still $9 \mathrm{ft}$ below minimum observed heads, three additional barrier cells in layer 4 (tapping the sand and gravel layer) were increased. This hypothetical scenario is called a breach wall because the barrier incompletely penetrates the sand and gravel layer. In a breach-wall scenario, inflow was sufficient and model-computed heads increased to observed heads.

Although a formal calibration was not performed, model-computed heads were checked against observed heads of interior extraction wells to assess model performance before and after allowing for the increased lateral inflow. Model $^{5}$ drawdowns at IW-1 and IW-2 were similar to observed drawdowns before increasing lateral inflow, indicating the hydraulic properties of the overburden in the interior barrier area are appropriate. Model-computed heads are generally insensitive to varying the amount of allowable lateral inflow given that the amount of lateral inflow exceeds the net extraction inside the barrier. Model-computed heads were also checked against observed heads from selected, continuously monitored, water-level observation wells to guide sensitivity tests. A detailed discussion of model calibration is presented in Harte (2004, p. 36-53).

Heads from layer 1 (not shown) and layer 4 (fig. 18), ground-water-flow vectors, and particle pathlines were ana-

\footnotetext{
${ }^{5}$ Model-computed drawdown was not adjusted in the comparison to correct for differences between cell size and well diameter. This correction is important for wells with large extraction rates. For OU1 extraction wells, differences between model-computed heads and heads at the interior wells, IW-1 and IW-1, are small (less than $0.5 \mathrm{ft}$ ), because of their low rates of extraction, according to Trescott and others (1976).
}

lyzed to assess ground-water flow into OU1. Interval contours of $0.5 \mathrm{ft}$ for model-computed head in layer 4 of the model are shown in figure 18 for 1999, 2001, and 2002 net extraction rates. The 1999 simulation (fig. 18A) assumes a fully penetrating barrier. The 2001 (fig. 18B) and the 2002 (fig. 18C) simulations assume a hypothetical breach wall in the sand and gravel layer near the PW-4 cluster wells (fig. 2). The extent of layer 4 ends to the west as the bedrock surface rises in this direction and layer 4 does not underlie the full perimeter of the barrier. The bottom of layer 4 corresponds to depths greater than $70 \mathrm{ft}$ below land surface (deep overburden).

Model-computed head contours are gentle within the barrier, sharp across the barrier, and more uniform outside of the barrier (fig. 18). Ground-water recharge from river seepage is prominent in all simulations (shown by upward bending head contours across the river). On the eastern, downgradient side of the barrier, a slow velocity zone is created from the shadow of the barrier. The increased injection rates in 2002 (fig. 18C) at the gallery causes head gradients to increase between the gallery and exterior extraction wells EW-1 and EW-2.

Ground-water velocity vectors are shown in figure 19 for 1999, 2001, and 2002 net extraction rates. The 1999 simulation (fig. 19A) assumes a fully penetrating barrier. The 2001 (fig. 19B) and 2002 (fig. 19C) simulations assume a hypothetical breach wall in the sand and gravel layer near PW-4 cluster wells (fig. 2). Velocity vectors represent the magnitude and direction of the average linear velocity across the cell. Vectors are drawn from the cell midpoint as a small square with a line segment extending outward toward the predominant flow direction. A minimum velocity of $1 \mathrm{e}-5 \mathrm{ft} / \mathrm{s}$ or $0.84 \mathrm{ft} / \mathrm{d}$ was used. Vectors from all model layers are shown and are projected to the surface for visualization purposes. In general, most of the vectors are from model layer 1 . Slow velocity zones are delineated by the absence of vectors. The barrier creates a slow velocity zone outside the barrier to the west (upgradient) and east (downgradient). Inside the barrier, velocity is slow (less than $0.84 \mathrm{ft} / \mathrm{d}$ ) except in the simulation for 2002, where hypothetically high rates of inflow under the barrier occur for the breach-wall scenario and because extraction rates were increased at IW-2. The mounding of the water-table surface at the recharge gallery creates a slow velocity zone upgradient between the river and gallery for all simulations. The slow velocity zone increases at the gallery as a result of an increase in rates of injection for 2002; therefore, solute transport of any contaminated ground water upgradient of the gallery decreases with an increase in gallery injection.

One-year capture zones in the overburden are shown in figure 20 as capture areas for IW-1 and IW-2 for 1999, 2001, and 2002 net extraction rates. The 1999 simulation (fig. 20A) assumes a fully penetrating barrier scenario. The 2001 (fig. 20B) and 2002 (fig. 20C) simulations assume a hypothetical breach-wall scenario in the sand and gravel layer near PW-4 cluster wells (fig. 2).

One-year capture areas were developed by backwardtracking particle pathlines from the extraction wells and terminated after 1 year of advective transport. Pathlines are 
A. 1999

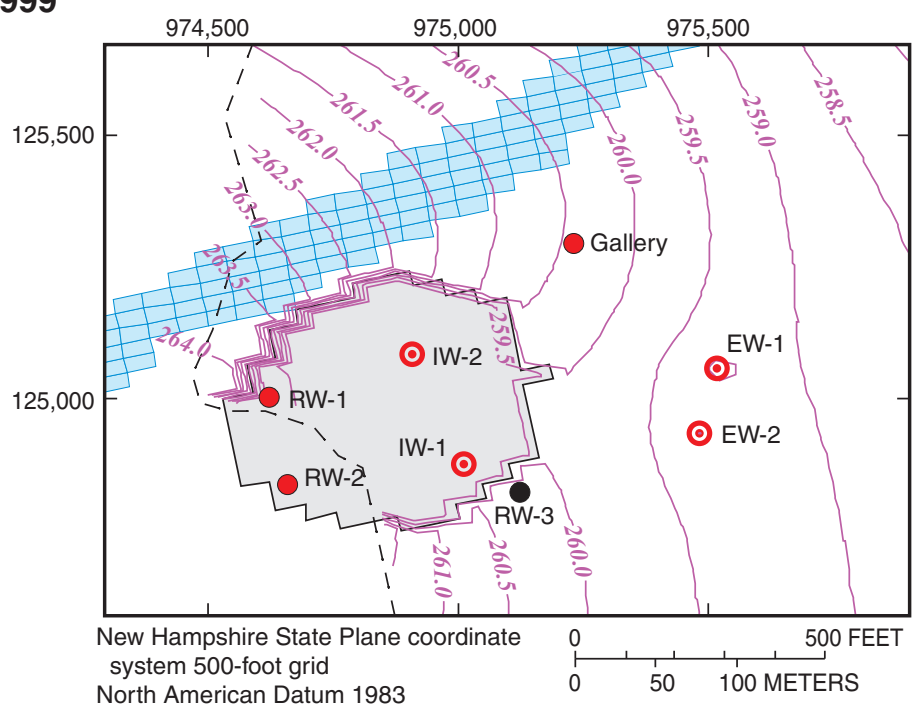

B. 2001

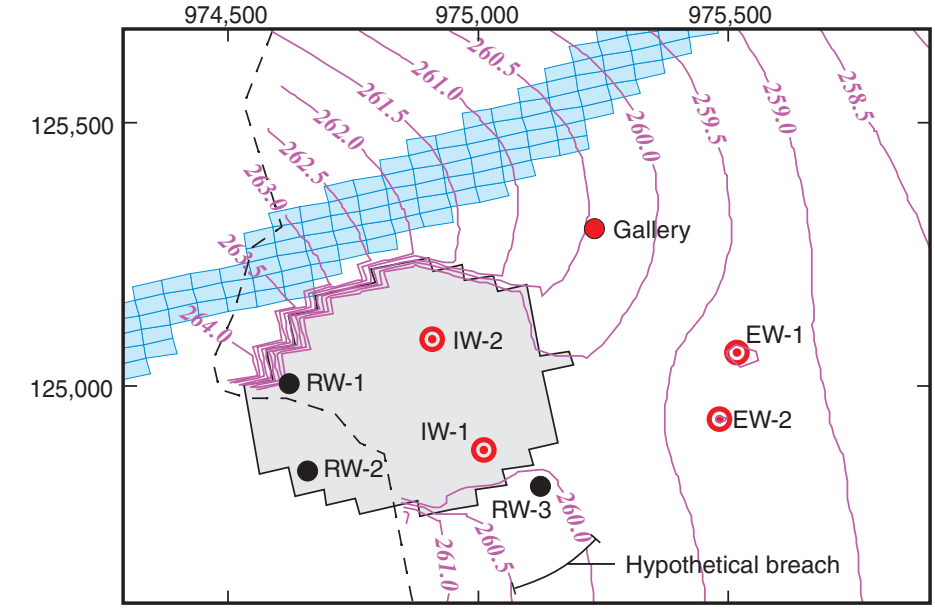

C. 2002

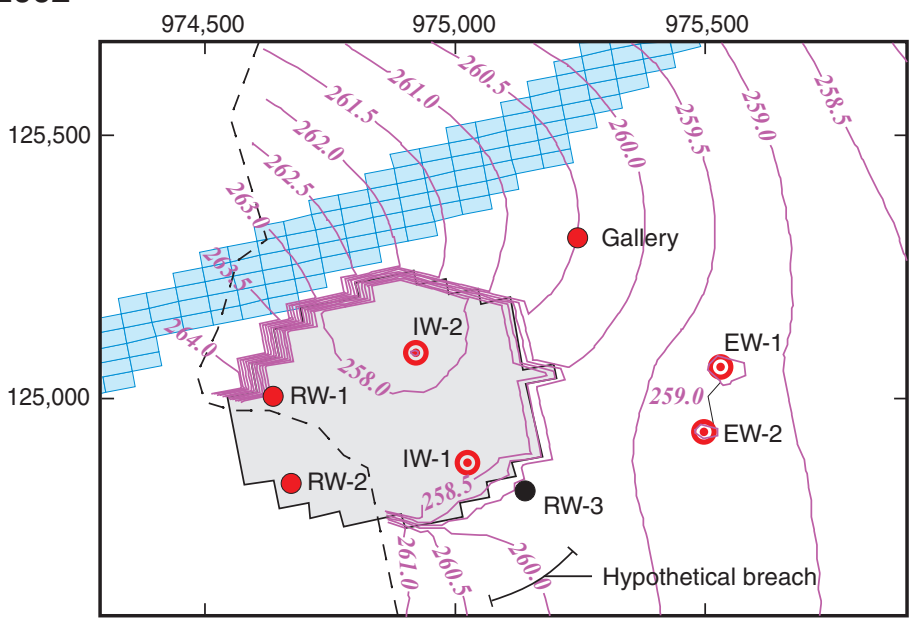

\section{EXPLANATION}

Simulated extent of interior barrier cell representing the barrier wall

Simulated river cell

- - - Extent of model layer 4

-259.0- Model-computed head contourContour interval 0.5 feet

$0^{\text {EW-1 }}$ Simulated operating remedial extraction well and name

$0^{\mathrm{RW}-1}$ Simulated operating remedial injection well and name

$0^{\text {RW-3 }}$ Simulated nonoperating remedial injection well and name

Figure 18. Model-computed head contours in layer 4 for remedial-operation rates in $A, 1999, B, 2001$, and $C, 2002,0$ perable Unit 1 (OU1), Milford, N.H. 
A. 1999

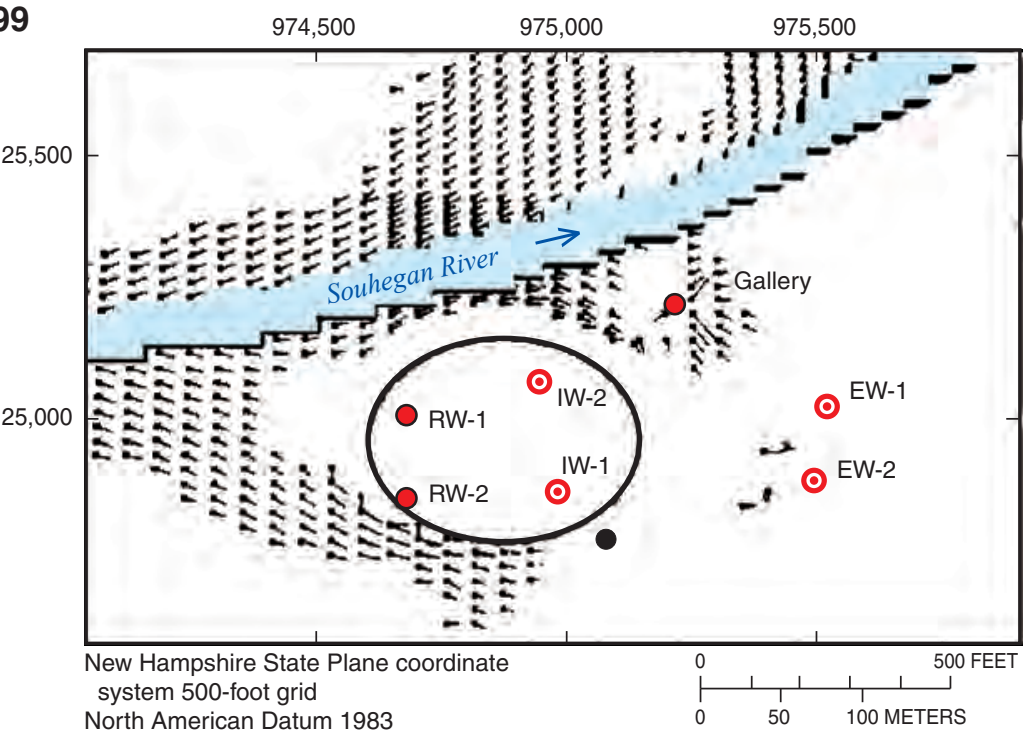

B. 2001 North American Datum 1983
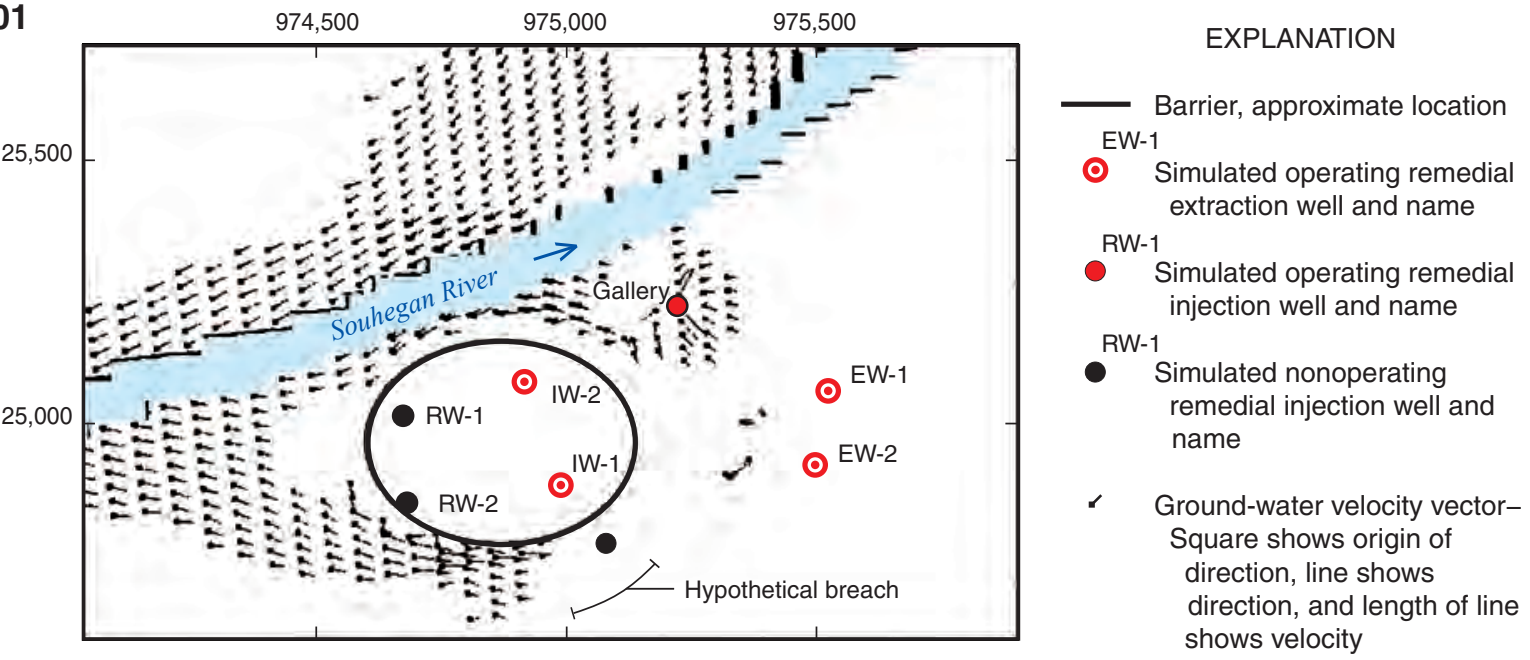

C. 2002

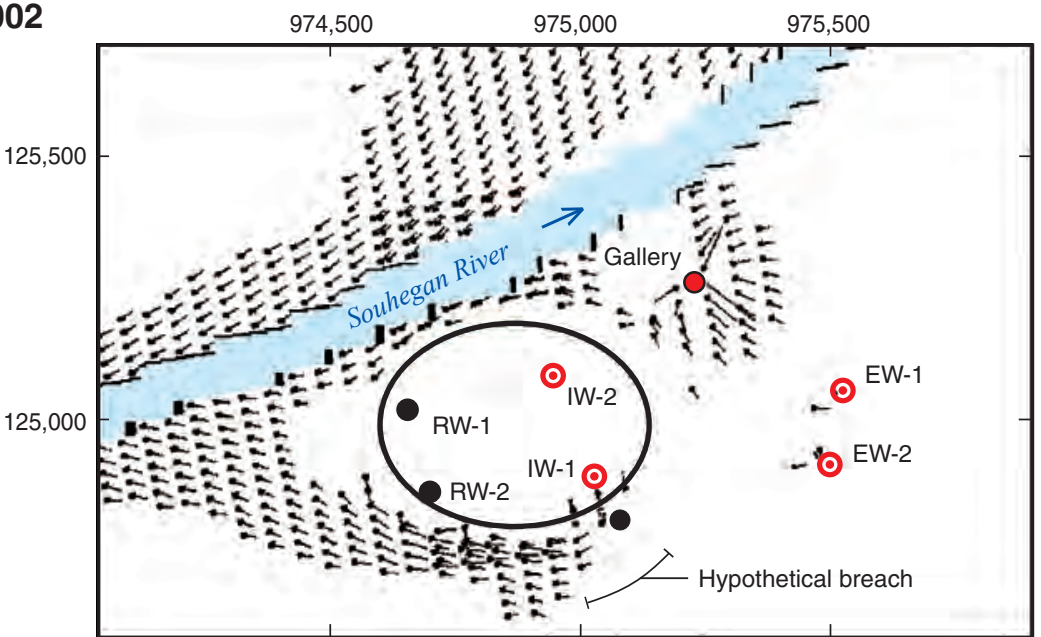

Figure 19. Model-computed horizontal ground-water velocity vectors for velocities above 0.84 feet per day for $A, 1999, B$, 2001, and C, 2002, Operable Unit 1 (OU1), Milford, N.H. 

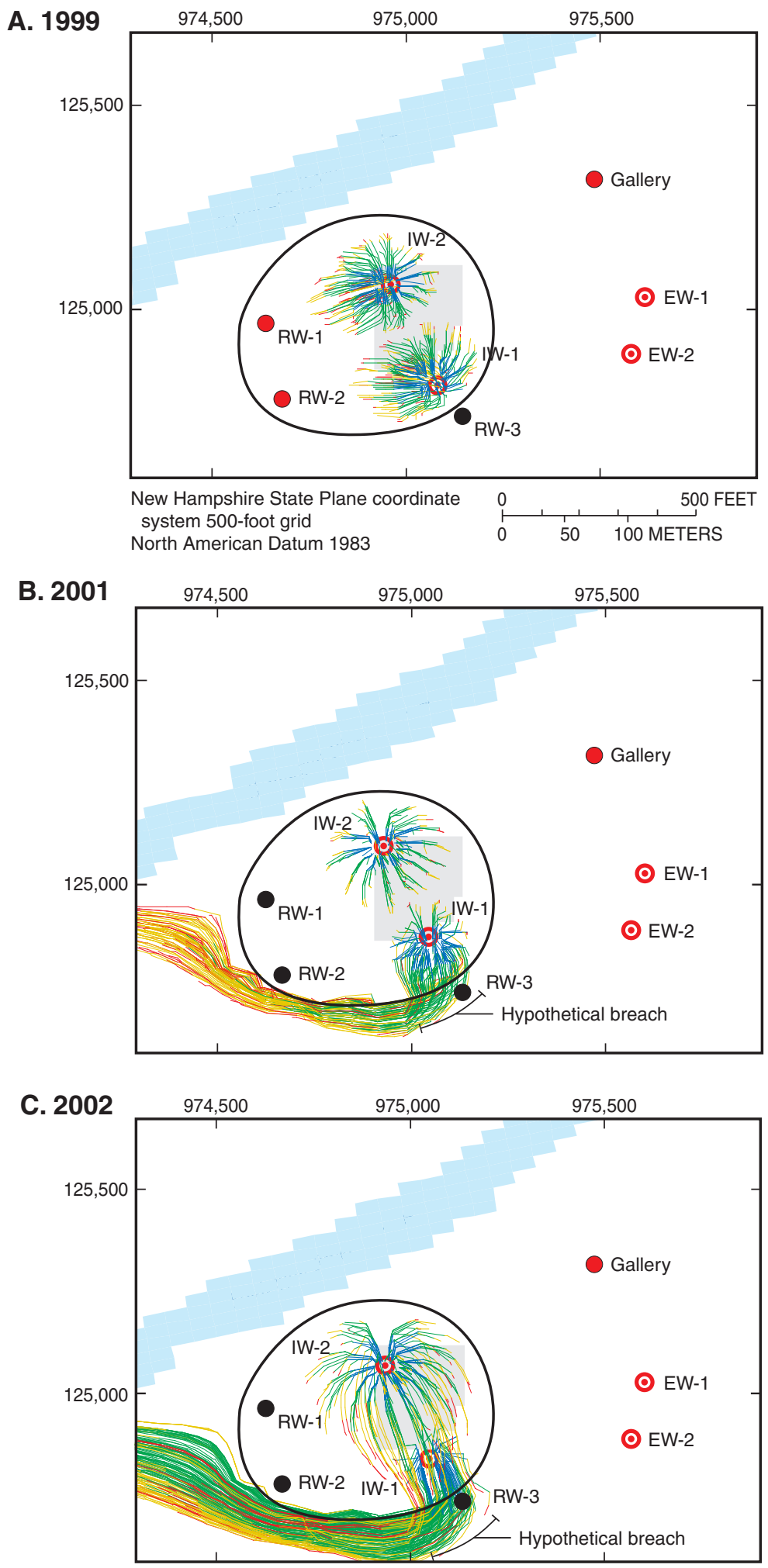

\section{EXPLANATION}

Simulated river cell

Bedrock upflow area (corresponds to thin basal till areas)

Barrier, approximate location

Tracked particle pathlines-

= Youngest-Less than 1 month

1 year

$0^{\text {EW-1 }}$ Simulated operating remedial extraction well and name

$0^{\mathrm{RW}-1}$ Simulated operating remedial injection well and name

RW-1

- Simulated nonoperating remedial injection well and name

Figure 20. Backward-tracked particles showing capture areas to IW-1 and IW-2 in $A, 1999, B, 2001$, and $C$, 2002, Operable Unit 1 (OU1), Milford, N.H. 
projected onto a two-dimensional surface, called capture area, but represent the projection of a three-dimensional capture zone. Therefore, for consistency purposes in this report, the term capture area will be used to describe the two-dimensional area or three-dimensional volume of water contributing to an extraction well. Colors denote ranges in travel times; blue lines represent less than 1 month and red lines represent approximately 1 year.

Results show that simulated inflow through the barrier from the breach barrier wall is clearly visible by particle pathlines that breach the barrier in the model (fig. 20B-C). The capture area for IW-1 and IW-2 are relatively small for 1999 rates (fig. 20A) because of the small extraction rates (less than $25 \mathrm{gal} / \mathrm{min}$ ) and because a part of the captured water is derived from ground-water upflow from the bedrock. For 1999 rates, the capture areas are skewed to the west because of the injection of water at RW-1 and RW-2. In the absence of injected water during 2001 and 2002, the capture area for IW-2 is more cylindrical and centered around the well (fig. 20B-C). For 2001 and 2002, the capture area for IW-1 extends past the barrier because of the arbitrary location of the assigned barrier breach.

Capture of contaminated PCE waters within the barrier is important for the long-term (greater than 10 years) success of remediation. PCE concentrations are high in the INEEL field (fig. 2) and concentrations are found in two distinct high PCE concentration layers, one shallow and one deep. Particle paths were forward tracked from shallow and deep locations to simulate advective transport from the INEEL field to their final discharge locations so as to evaluate the effectiveness of different internal net-extraction rates.

For the three net-extraction rates (1999, 2001, and 2002) and the simulated underflow conditions, the time-to-discharge of particles (or capture) by the IW-1 and IW-2 wells varied. Advective transport from the INEEL field, and capture by one of the two interior extraction wells, is fastest for 2002 and slowest for 2001. Although capture is quickest in 2002, the simulation results indicate a more efficient remedial operation in 1999 considering that 2002 extraction rates are doubled that of 1999 . For 1999 rates, the shallow plume is captured in 2 years and flows to IW-1, whereas the deep plume is captured in 5 years to the same well. For 2001, the shallow plume is captured in 5 years and flows to IW-2, whereas the deep plume is captured in 10 years and also flows to IW-2. For 2002, the shallow plume is captured in 2 years and flows to IW-2, whereas the deep plume is captured in 4 years to the same well.

\section{Sensitivity of Inside Barrier Area to Upflow from Bedrock}

Another source of water to interior extraction wells is bedrock upflow (eq. 1). Whereas the previous simulations tested the effects of horizontal lateral inflow in the overburden into the interior barrier area, analysis of available monitoring data indicates a more likely scenario that interior extractions are augmented by increased vertical ground-water upflow from the bedrock. The effect of varying the amount of bedrock upflow is discussed in this section (table 6; simulation type-_Evaluation of bedrock upflow").

Available monitoring data indicate bedrock upflow is an important component of the interior barrier area groundwater budget. Continuously monitored ground-water levels at cluster wells show that the bedrock ground-water levels respond quickly to variations in net extraction inside the barrier (fig. 7). This quick response indicates that variations in bedrock upflow occur with variations in net extraction and increases in net extraction inside the barrier induce increases in bedrock upflow. Observed head gradients within the barrier in the overburden are low (head differences less than $0.5 \mathrm{ft}$; Harte 2005) between well B95-9 and PW-5D (fig. 2). The low observed gradients inside the barrier indicate recharge is diffuse and likely from upward flow from the bedrock. In contrast, steep gradients (head differences greater than $0.5 \mathrm{ft}$; Harte, 2005) in the overburden across the barrier from wells that straddle the barrier indicate the barrier penetrates the overburden in those locations. This is additional evidence indicating upflow from bedrock is an important factor in the overburden water budget of the interior barrier area.

Unlike the simulations testing variations in the amount of allowable lateral inflow, model-computed heads are sensitive to variations in rates of upflow from the bedrock. If there is too much upflow, heads become too high; if too little upflow, heads dewater inside the barrier.

For 2002 conditions and complete penetration in the overburden by the barrier (no breach), a bedrock upflow rate of up to $35.25 \mathrm{gal} / \mathrm{min}$ is required to maintain the net extraction rate of $37 \mathrm{gal} / \mathrm{min}$, which is equal to the net extraction rate of $37 \mathrm{gal} / \mathrm{min}$ minus the minimum aerial recharge rate of $1.75 \mathrm{gal} / \mathrm{min}$. In this scenario, the capture areas for IW-1 and IW-2 are entirely within the barrier (fig. 21). However, because of the relatively high rates of upflow from the bedrock, the capture areas do not extend throughout the interior barrier area and are limited to the eastern part of the interior barrier area.

An important condition to consider when examining capture areas is that the capture areas are limited to the overburden because the model does not directly simulate the underlying bedrock. The model indirectly simulates the contribution of bedrock as an assigned upward flow rate at the base of the overburden. If the source volume of the bedrock upflow was simulated, particle pathlines would extend into the bedrock in areas possibly outside the barrier.

In March 2003, rates of extraction at interior wells IW-1 and 2 were increased to $60 \mathrm{gal} / \mathrm{min}$ total (30 each) and injection was distributed outside the barrier to the gallery and a small amount (less than $20 \mathrm{gal} / \mathrm{min}$ ) to the exterior injection well RW-3 (fig. 2). Because of the large rate of bedrock upflow (approximately $58 \mathrm{gal} / \mathrm{min}$ ) needed to augment interior extraction under a no-breach condition, the heads in layer 5 became too high when the hypothetical injection-well rates 


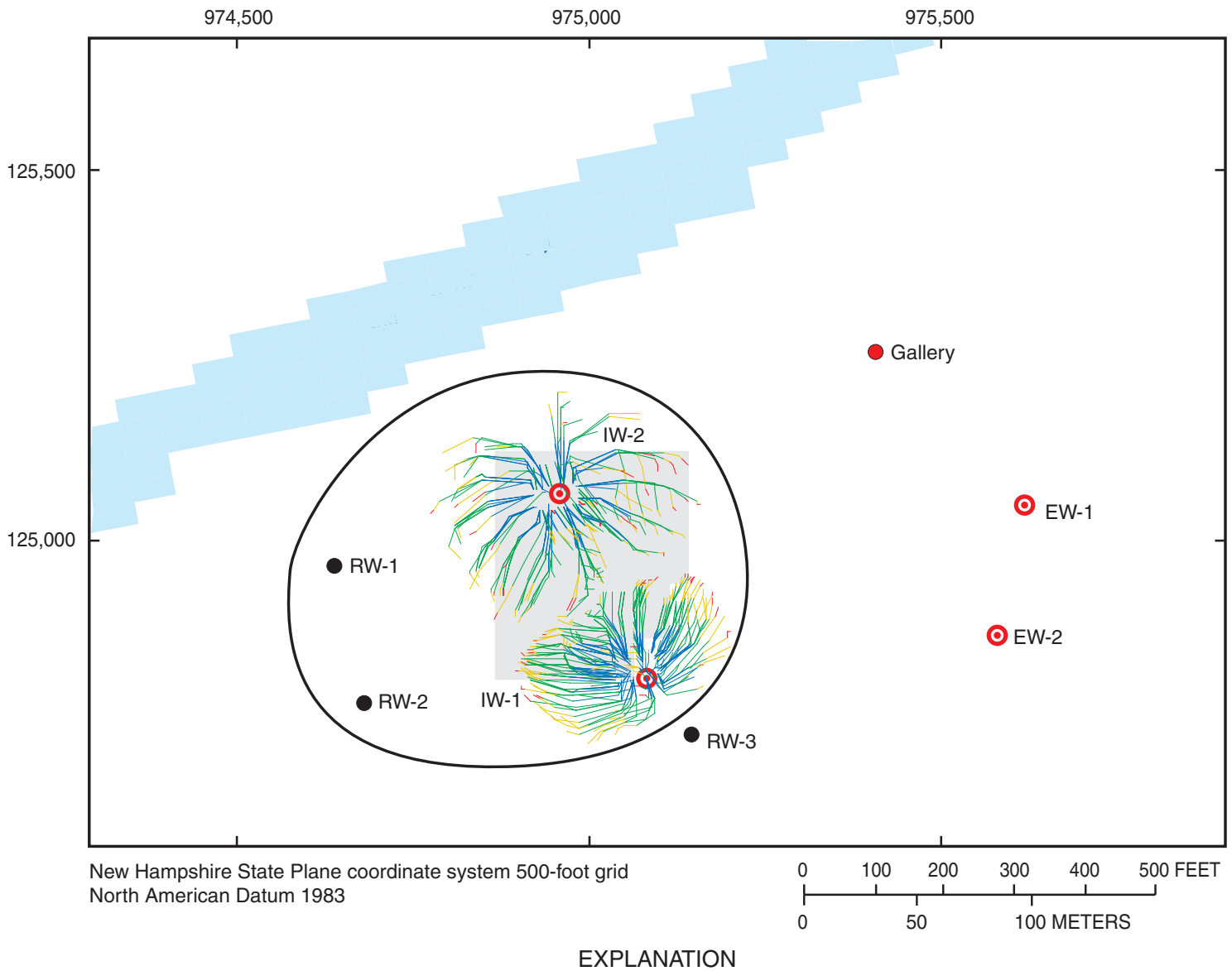

Simulated river cell

Bedrock upflow area (corresponds to thin basal till areas)

Barrier, approximate location

Tracked particle pathlines-

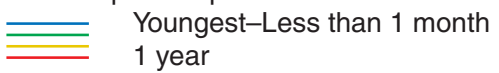

$0^{E W-1}$

Simulated operating remedial extraction well and name

Gallery

Simulated operating remedial injection well and name

RW-1

Simulated nonoperating remedial injection well and name

Figure 21. Backward-tracked particles showing capture areas to IW-1 and IW-2 with no horizontal inflow under the barrier in layer 5, 2002 rates, Operable Unit 1 (OU1), Milford, N.H. 
were increased to $58 \mathrm{gal} / \mathrm{min}$ because of the low hydraulic conductivity assigned to some of this layer ( $5 \mathrm{ft} / \mathrm{d}$ in the till). Therefore, it was necessary to simulate bedrock upflow under a breach-barrier condition to allow some additional inflow to augment net extraction. A reasonable simulation was achieved with a maximum bedrock upflow rate of $49 \mathrm{gal} / \mathrm{min}$. Model results are constrained by the limitations of the current boundary conditions and model, and more realistic model results may be achieved by adding the bedrock as a new layer in the model.

\section{Sensitivity of Outside Barrier Area on Capture Areas to Exterior Extraction Wells}

The capture areas to the exterior extraction wells (EW-1, and EW-2) are examined in this section. The capture areas for EW-1 and EW-2 are affected by the barrier wall, recharge from the adjacent Souhegan River and by injection at the gallery, and stresses (extraction) from wells located outside of OU1. These factors were simulated in the model. RW-3 was not simulated because of sporadic operations.

For the study periods (1999, 2001, and 2002), variation in extraction was minimal at EW-1 and EW-2 (fig. 22); therefore, extraction rates for EW-1 and EW-2 were kept constant at $25 \mathrm{gal} / \mathrm{min}$. The amount of injection at the gallery increased from 59.6, to 62.9 , to $90 \mathrm{gal} / \mathrm{min}$ in 1999,2001 , and 2002 , respectively. The simulated head from the increased injection at the gallery is less than $1 \mathrm{ft}$ because of the high horizontal hydraulic conductivity $(450 \mathrm{ft} / \mathrm{d}$ ) assigned to layer 1 of the model to simulate the cobble layer. Yet, even with this small head change, the capture areas for EW-1 and EW-2 are affected by the rate of injection at the gallery.

The 1-year capture areas are shown for EW-1 and EW-2 in figure 22. Particle paths were backward-tracked from the extraction wells and ended after 1 year of advective transport. Capture areas are from 1999 (fig. 22A), 2001 (fig. 22B), and 2002 (fig. 22C). The barrier and the Souhegan River bound the capture areas of EW-1 and EW-2. The most important difference in simulated capture areas is the amount of recirculated water from the gallery that is captured by EW-1. As injection rates increase at the gallery, so does the amount of injected water captured by EW-1. As a result, the extent of the two capture areas (EW-1 and EW-2) varies particularly to the south.

Only a percentage of gallery-injected water is captured by EW-1. Simulated forward-tracking of particles from the gallery (not shown in any figure) indicates that gallery-injected water covers a lateral area from EW-1 to $200 \mathrm{ft}$ north of the PW-13 cluster (fig. 2). The percent of particles tracked from the gallery that is captured by EW-1 increases from 11 percent in 1999 , to 16 percent in 2001, and to 18 percent in 2002 .

Exterior stresses in the aquifer affect the capture areas of EW-1 and EW-2 (fig. 23). Termination of withdrawals at an industrial well (MI-88, fig. 1) to the south of OU1 affects the capture areas of EW-1 and EW-2. This relation indicates that the northern edge of the capture area for MI- 88 bounds the southern edge of capture areas for EW-1 and EW-2. When withdrawals are terminated at MI-88 (fig. 23B), the capture area of EW-1 and EW-2 spreads further south by approximately $150 \mathrm{ft}$.

\section{Effects of Transient Flow on Capture Areas to Exterior Extraction Wells}

Differences in capture areas between steady-state and transient models were examined to assess the effect of transient conditions on capture to EW-1 and EW-2 because variations in transient seasonal capture areas could affect remedial effectiveness. Unlike the steady-state model, the transient model incorporates storage and monthly variation in recharge and river stage and follows seasonal trends described in Harte (1999, table 6, medium recharge rate). The starting condition for the transient model is the steady-state simulation of 1999 (fig. 18A), which provides an appropriate initial condition of head. Extraction rates at EW-1 and EW-2 were kept constant at $25 \mathrm{gal} / \mathrm{min}$ for the steady-state and transient simulations.

The capture areas to EW-1 and EW-2 are dynamic in that 1-year travel times to these wells cover a large area. Travel times to EW-1 and EW-2 are young (less than 1 month) because of the high hydraulic conductivity of the aquifer and location of the wells near the river. The river is a major source of recharge for the aquifer with an average recharge of several cubic feet per second. One-year travel times to the wells cover more than 90 percent of the capture area, therefore, annual capture areas were used to assess the affect of transient conditions.

The annual capture area is 30 percent larger for the transient simulation than for the steady-state simulation. The major differences between the simulations are that the transient capture area extends farther to the south than the steadystate capture area. This area of the aquifer, as of 2004, has low to non-detectable levels of VOCs (Leah Desmarais, New Hampshire Department of Environmental Services, written commun., 2004); therefore, increased ground-water capture of water south of the barrier decreases efficiency of remediation (contaminant mass removed per gallon of water extracted).

To estimate the effect of capture of contaminated ground water as a result of transient conditions, further testing was done to identify differences between capture areas under steady-state and transient conditions. A line source of particles were placed directly downgradient from the barrier wall, from west of the recharge gallery to RW-3 (fig. 2), to simulate the advective transport of contaminated ground water outside the barrier. Particles were released semi-annually in the middle layer (layer 3 of the solute-transport model). Two different start dates were used, June and December. Simulations starting in June begin during a low precipitation-recharge period. Simulations starting in December begin during a high precipitation-recharge period. Ranges of simulation periods included 4 months (June-September, and December-March), 6 months (June-November, and December-May), 8 months 
A. 1999

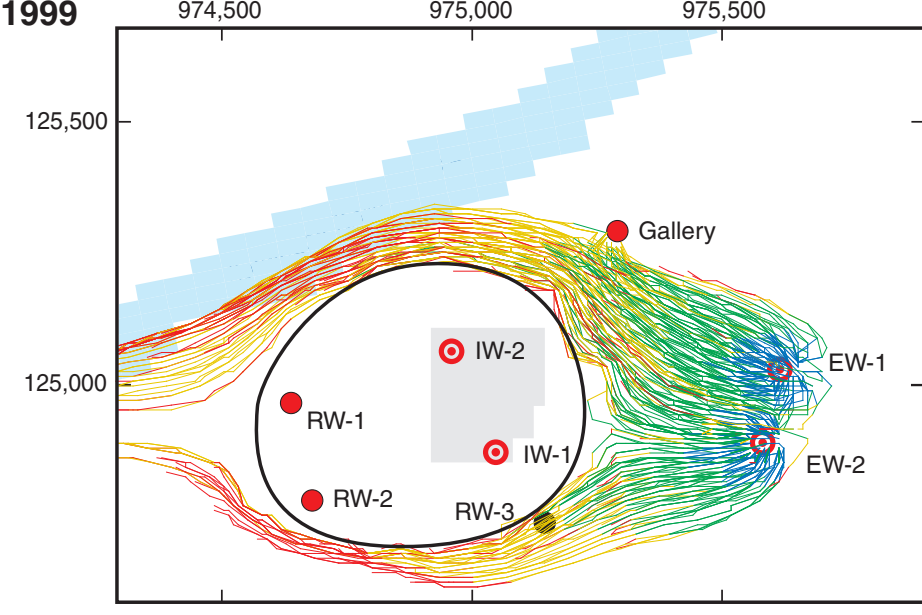

New Hampshire State Plane coordinate system 500-foot grid

North American Datum 1983

B. 2001

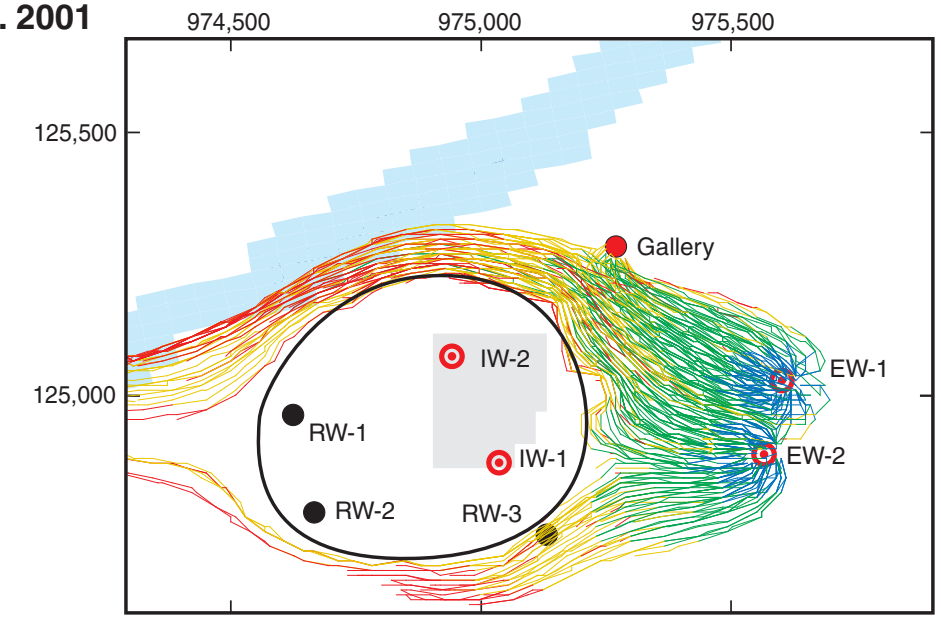

C. 2002

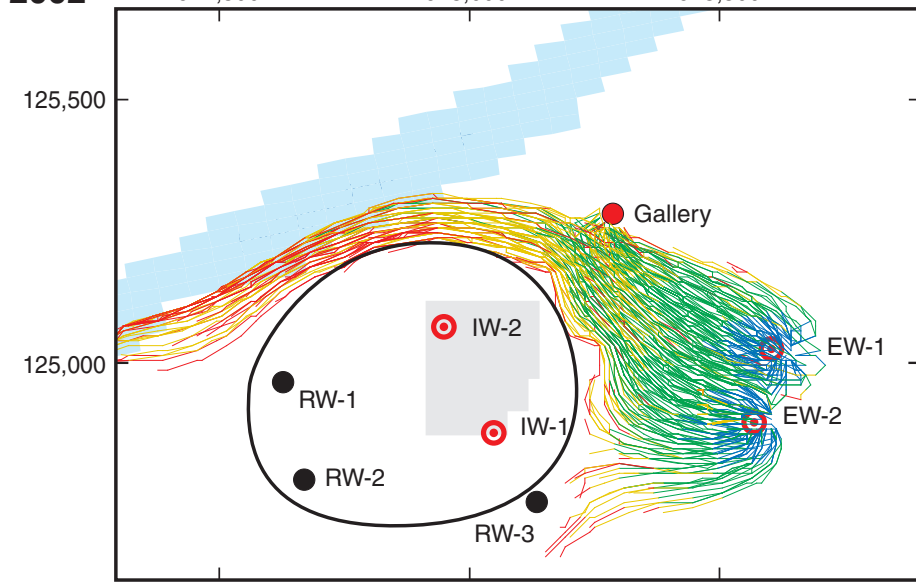

\section{EXPLANATION}

Simulated river cell

Bedrock upflow area (corresponds to thin basal till areas)

- Barrier, approximate location

Tracked particle pathlines-

Youngest-Less than 1 month 1 year

${ }^{\text {EW-1 }}$ Simulated operating remedial extraction well and name

$0^{R W-1}$ Simulated operating remedial injection well and name

- $^{\mathrm{RW}-1}$ Simulated nonoperating remedial injection well and name

Figure 22. Backward-tracked particles showing capture areas to EW-1 and EW-2 in A, 1999, B, 2001, and C, 2002, Operable Unit 1 (OU1), Milford, N.H. 
A.

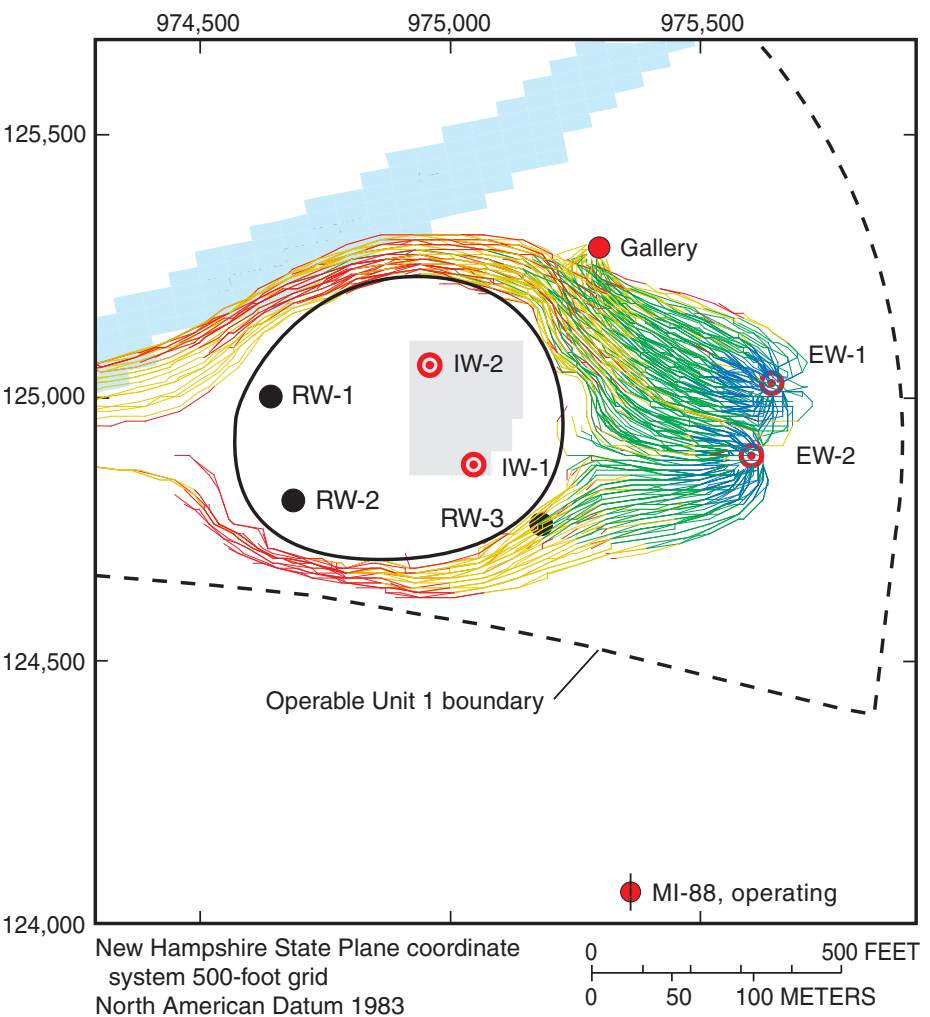

\section{EXPLANATION}

Simulated river cell

Bedrock upflow area (corresponds to thin basal till areas)

Barrier, approximate location

Tracked particle pathlines-

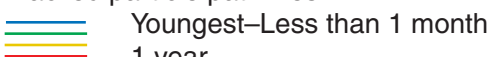
1 year

B.

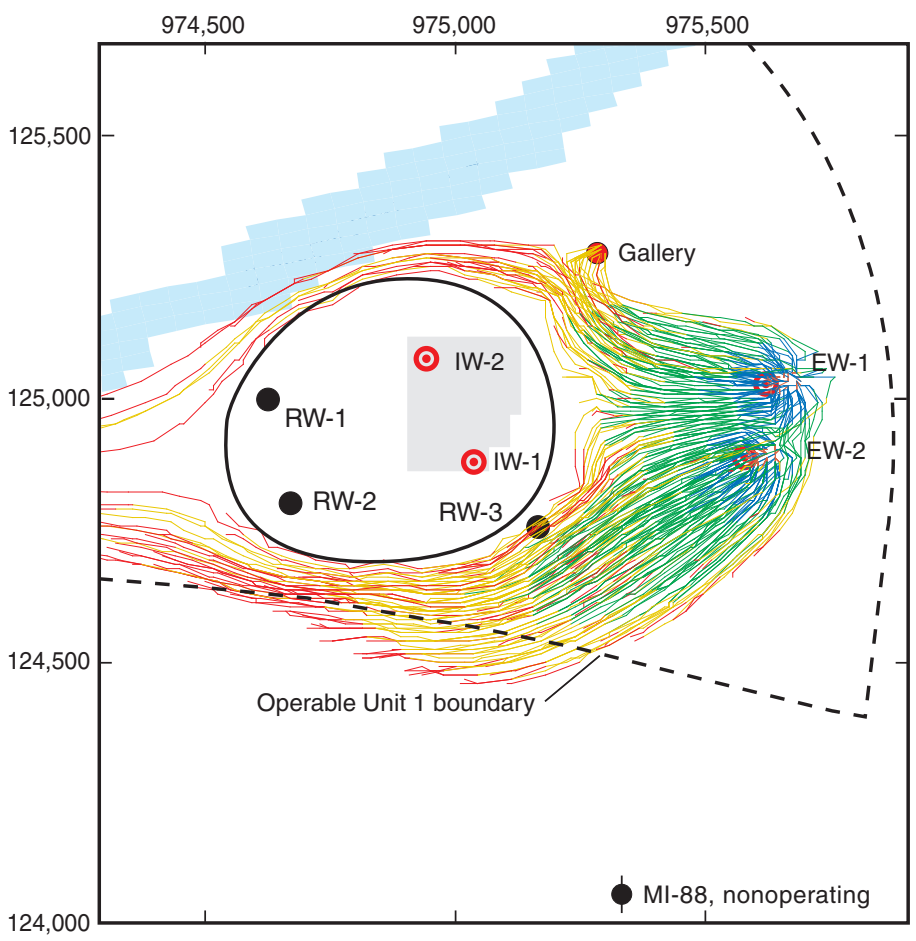

${ }^{\mathrm{EW}-1}$ Simulated operating remedial extraction well and name Gallery

Simulated operating remedial injection well and name

${ }^{\mathrm{RW}-1}$ Simulated nonoperating remedial well and name

MI-88

Industrial withdrawal well and name

Figure 23. Backward-tracked particles showing capture areas to EW-1 and EW-2 for 2002 rates $A$, with, and $B$, without withdrawals from MI-88, Operable Unit 1 (OU1), Milford, N.H. 
(June-January, and December-July), and 1 year (June-June, December-December).

Over the annual cycle, less than a 2-percent difference in capture of particles resulted between transient and steadystate simulations (table 6). During shorter periods of time (4 months), up to a 29-percent difference in capture resulted. Simulations starting in December captured more particles than those starting in June. The steady-state simulation captures an equal number of particles for any 4-month period because velocity and flow direction is constant throughout the year. Capture of particles in the transient simulations brackets the results of the steady state indicating that the steady-state model represents an average capture condition. The differences in capture between the June and December transient simulations are a function of variations in flow direction and particle velocity.

Ground-water gradients and flow direction in OU1 are affected by surface- and ground-water interactions. The amount of aquifer recharge from the losing river reach in OU1 affects ground-water-flow direction outside the barrier. Harte (1999) showed that maximum gradients occur during low water-table conditions in the aquifer because aquifer recharge from the river reach in OU1 is highest during this period. When recharge is highest from the river, more flow occurs from the river area toward EW-1 and EW-2.

Less particles from in front of the barrier are captured in the summer because more water is being captured by EW-1 and EW-2 from the river area north of the barrier, away from areas where particles were placed. In particles starting in December, a high direct-infiltration recharge period, river loss and gradients from the river are at their lowest and less water is captured by EW-1 and EW-2 from the river area. In particles starting in June, a low direct-infiltration recharge period, river loss and gradients from the river are at their highest and more water is captured from the river area.
Extraction rates at EW-1 and EW-2 (25 gal/min each) adequately capture contaminants during high recharge periods because more particles are being captured from outside the barrier than during low recharge periods. Optimization of capture would improve if withdrawals were modified on the basis of seasonal climate trends to more effectively capture contaminants from outside the barrier. For example, reduced extraction at EW-1 and EW-2 during the summer captured less uncontaminated water from the river area. Increased extraction at EW-1 and EW-2 during the winter captured more contaminated water outside the barrier.

\section{Alternative Operational Schemes to Accelerate Flushing of Contaminants}

PCE-concentration decreases from 1998 to 2004 (table 3) outside the barrier in OU1 at PW-14M were potentially small as a result of the formation of a small stagnant area downgradient from EW-1 and EW-2 caused by low ground-water velocities. Alternative operational schemes at EW-1 and EW-2 were investigated to determine whether ground-water velocities at PW-14M could be increased by modifying injection rates. PCE-concentration decreases at PW-14M from 1999 to 2004 were small (table 3). Increased ground-water velocities near PW-14M accelerated flushing of contaminated ground water in this area.

The flushing of pore volume by ground water can be increased by modifying the existing injection operation. The base and current (2004) operation has most of the water at OU1 being injected into the recharge gallery. Under this operation, one model-computed pore volume is flushed every 46 days at the model cell containing PW-14M (layer 4; table 7). Relocating the gallery approximately $100 \mathrm{ft}$ east of EW-2 caused an increase in flushing of one pore volume of

Table 7. Advective transport and capture of a line-source of ground-water particles from steady state and transient models, Operable Unit 1 (OU1), Savage Municipal Well Superfund site, Milford, N.H.

[June 1 and December 1 start dates for tracking with transient model; --, no data]

\begin{tabular}{|c|c|c|c|c|c|c|c|c|}
\hline Simulation & \multicolumn{2}{|c|}{ Four months } & \multicolumn{2}{|c|}{ Six months } & \multicolumn{2}{|c|}{ Eight months } & \multicolumn{2}{|c|}{ One year } \\
\hline Steady state & 28 & 22 & 105 & 82 & 113 & 44 & 220 & 86 \\
\hline Difference & 8 & -- & 7 & -- & 6 & -- & 4 & -- \\
\hline $\begin{array}{l}\text { Percent difference } \\
\text { from steady state }\end{array}$ & 29 & -- & 6 & -- & 5.3 & -- & 1.8 & -- \\
\hline
\end{tabular}


Table 8. Simulations testing alternative injection locations outside the barrier wall for Operable Unit 1 (OU1), Savage Municipal Well Superfund site, Milford, N.H.

[Location of wells shown on figure 2; site type names explained in abbreviation section of report; EW, exterior extraction well; ft, feet]

\begin{tabular}{|c|c|c|c|c|}
\hline $\begin{array}{l}\text { Description of simulation testing } \\
\text { location of injection }\end{array}$ & $\begin{array}{l}\text { OU1 operational } \\
\text { rates }^{1}\end{array}$ & $\begin{array}{l}\text { Volumetric flow into } \\
\text { model cell at well PW-14M, } \\
\text { in gallons per minute }\end{array}$ & $\begin{array}{l}\text { Number of days to } \\
\text { flush one pore water } \\
\text { volume for model cell } \\
\text { at well PW-14M }\end{array}$ & $\begin{array}{l}\text { Injection } \\
\text { model layer }\end{array}$ \\
\hline Existing gallery location & March 2003 & 0.71 & 46 & 1 \\
\hline $100 \mathrm{ft}$ east of EW-2 in layer 1 & March 2003 & .95 & 34 & 1 \\
\hline In EW-1 & March 2003 & .81 & 40 & 4 \\
\hline
\end{tabular}

${ }^{1}$ March 2003 rates include wells EW-1 and EW-2 at 15 gallons per minute (gal/min) each, wells IW-1 and IW-2 at 31 gal/min each, well RW-3 at $17 \mathrm{gal} / \mathrm{min}$, and $75 \mathrm{gal} / \mathrm{min}$ in injection gallery or new well. Source of data: U.S. Filter, Inc., written commun., 2003.

water near PW-14M from 46 to 34 days compared to the previous simulation (table 7). Converting the injection at a gallery in layer one to an injection well screened in layer 4 at this same location modestly increases flushing from 34 to 31 days (table 7). If the injection well is moved approximately $50 \mathrm{ft}$ north, flushing increases dramatically (22 days in table 7) indicating the horizontal changes in injection location are more important than vertical placement.

Utilizing an existing exterior extraction well as an injection well does little to increase flushing at PW-14M. Switching EW-1 from an extraction well to an injection well causes the flushing rate to decrease by only 5 days (table 7) from the base rate of 45 days.

Simulations were used to evaluate the feasibility of increased flushing of ground water near the small PCE stagnant zone. These simulations indicate that enhanced flushing can be achieved by optimal horizontal placement of injection downgradient from EW-1 and EW-2 in layer 1. Only a slight additional benefit was achieved from varying vertical placement. Not shown in any figure, but tested as a simulation, was the effect of increased flushing at PW-14M when all extraction was discontinued at EW-1 and EW-2. A 15-percent increase in flushing was achieved when extraction was discontinued.

\section{Evaluation of Effectiveness of Remediation}

From 1998 to 2004, PCE concentrations decreased by an average of 80 percent at most wells outside the barrier. This decrease indicates (1) the barrier and interior extraction have effectively contained high PCE concentrations within the barrier, (2) other sources of PCE did not appear to be present outside of the barrier, and (3) ambient ground-water fluxes and velocities in conjunction with the exterior remedial wells effectively continued to remediate most of the dissolved PCE plume outside the barrier.

The middle overburden downgradient of exterior (to barrier) extraction wells shows slow (less than 50 percent) decreases in PCE concentrations, at least partly because of the formation of a small downgradient slow-velocity zone based on numerical simulations. Because the ambient ground-water velocities are high $(1 \mathrm{ft} / \mathrm{d})$, discontinuing extraction at the exterior wells may increase flushing by 15 percent in this area. An alternative approach is to relocate the injection gallery or locate a new injection well to an area east of the exterior wells.

If the existing exterior remedial system is maintained, adjusting extraction at EW-1 and EW-2 based on seasonal trends in recharge would increase the efficiency of capture of contaminated ground water. Seasonal trends in direct infiltration recharge from precipitation and recharge from river leakage cause directional variations in flow that affect capture of the contaminated ground water by the existing exterior extraction wells as shown by numerical simulations of transient hydrologic conditions. Monitoring data indicate that maximum gradients and recharge from the losing river reach in OU1 are generally during low water-table conditions (Harte, 1999). Therefore, if exterior extraction at EW-1 and EW-2 is turned off during low recharge periods (summer), then less, relatively clean ground water from the river area is captured. Conversely, increasing extraction during high recharge periods (early spring) would capture more contaminated ground water from outside the barrier.

PCE-concentration decreases inside the barrier from 1998 to 2003 (before ISCO treatment) were slow near suspected source areas, which indicate that the existing remedial system is inefficient in remediating either dissolved PCE or the DNAPL source within the barrier. Operation of soil-vaporextraction wells and air-sparge wells has been limited by factors such as the inability to lower the water-table surface inside the barrier. Large amounts of ground-water upflow 
from the underlying fractured bedrock allow water to enter the barrier area in the overburden and prevent dewatering, which compromises the effectiveness of capture of contaminants in the overburden. Capture of the dissolved PCE plume may be increased by using existing injection wells to increase the hydraulic gradient inside the barrier. As the gradient increases, contaminated ground water would move more quickly toward the interior extraction wells.

\section{Summary and Conclusions}

The U.S. Geological Survey (USGS), in cooperation with the New Hampshire Department of Environmental Services (NHDES) and the U.S. Environmental Protection Agency (USEPA), Region 1, has investigated the effectiveness of the remediation system at Operable Unit No. 1 (OU1), which contains the primary source area of volatile organic compounds (VOCs), at the Savage Municipal Well Superfund site (Savage site) in Milford, N.H. This project is one of several continuing evaluations of the site by NHDES and USEPA.

The OU1 remedial system includes a low-permeability (bentonite) barrier wall (barrier) that encircles the highest detected concentrations of tetrachloroethylene (PCE), which is the primary VOC, and a series of injection and extraction wells. The barrier likely penetrates the full thickness of the sand and gravel; in most places, it also penetrates the full thickness of the underlying basal till and sits atop bedrock.

The overburden stratigraphy of the OU1 site from land surface downwards includes a shallow cobble layer, a sand lens, several coarse-grained sand and gravel layers, and discontinuous till that thickens to the west. The sand and gravel has complex stratigraphy and it is laterally and vertically discontinuous.

Ground-water flow is from west to east and includes significant recharge (several cubic feet per second) from the Souhegan River, which is primarily a losing river reach in OU1. The construction of the barrier has focused river loss to an area northeast of the barrier. During remedial operation of injection and extraction wells, ground-water flow is complex and several stagnation areas (relatively slow velocity zones) form. Outside the barrier, small stagnation areas are upgradient from injection at a recharge gallery, and downgradient from extraction at exterior remedial wells EW-1 and EW-2. Inside the barrier, extraction at interior remedial wells IW-1 and IW-2 causes flowpaths to diverge, which contributes to the formation of zones of slow ground-water velocity or stagnation zones.

Continuously monitored water-level responses to remedial extraction inside the barrier show that (1) bedrock is hydraulically connected to the overburden, and (2) extraction at interior overburden wells IW-1 and IW-2 induces groundwater upflow from the fractured bedrock. A water budget for the interior barrier area indicates bedrock upflow contributes greater than 50 percent of the source of water for the interior extraction wells.

Numerical simulations show that ground-water upflow from the bedrock reduces the size of the capture areas to the interior extraction wells. For this reason, interior extraction capture areas are small and less effective in inducing transport of high PCE concentrations dissolved from overburden DNAPL source zones inside the barrier. Use of existing injection wells inside the barrier can increase the existing shallow horizontal gradients and promote flow of high PCE concentrations toward extraction wells.

Simulations show that capture areas of the exterior extraction wells EW-1 and EW-2 are affected by the Souhegan River, injection at the recharge gallery, the barrier wall, and a neighboring capture area from an industrial well to the south. Increased injection at the gallery increases the amount of water recirculated and captured by the exterior extraction wells.

Based on simulations of transient capture areas of the exterior extraction wells, the Souhegan River affects capture. During low direct-infiltration recharge periods in the summer, recharge from the river is at a maximum causing the exterior extraction wells to capture additional water from areas north of the barrier by the river. During high direct-infiltration recharge periods in late fall, recharge from the river is at a minimum causing additional water to be captured by the exterior extraction wells from outside the barrier on the downgradient side. Because PCE concentrations are greatest in front of the barrier, optimizing capture from in front of the barrier area would be advantageous.

From 1998 to 2004, large decreases (80 percent reduction) in PCE concentrations have been measured at many observation wells outside the barrier. However, there are several areas where PCE concentrations decrease slowly, including an area downgradient from the exterior extraction wells outside the barrier and in areas near source zones inside the barrier. Velocities in slow-velocity zones downgradient from the exterior extraction wells can be increased by modifying the existing injection system or terminating extraction during periods of low direct recharge when horizontal head gradients are greatest from the river. Slow decreases in PCE concentrations inside the barrier are more problematic and require more aggressive source treatment. Interior barrier areas with high PCE concentration would also benefit from increased flushing by operating existing interior injection wells and by increasing horizontal head gradients.

\section{References Cited}

Brayton, M.J., and Harte, P.T., 2001, Results of a monitoring program of continuous water levels, specific conductance, and water temperature at the OK Tool facility of the Savage Municipal Well Superfund site, Milford, New Hampshire: U.S. Geological Survey Open-File Report 01-338, 50 p. 
Camp, Dresser, and McKee, Inc., Federal Programs Corporation, 1995, Final report of vertical contaminant profiling, Savage Municipal Supply Well, Superfund site-OU1, Milford, New Hampshire: Boston, Mass., November 1995, 5 chaps., 5 apps.

Camp, Dresser, and McKee, Inc., 1996, Conceptual remedial design report for OK tool source area, Savage Municipal Supply Well, Superfund site-OU1, Milford, New Hampshire: Cambridge, Mass., March 1996, v. 1, 5 chaps., variously paginated.

Camp, Dresser, and McKee, Inc., 2001, Summary of investigations Re: Draining of bulk solvent storage tank, OK Tool/ Savage Municipal Supply Well, Milford, New Hampshire: Cambridge, Mass., November 2001, variously paginated.

Environmental Science and Engineering, Inc., 1995, Results of vertical profiling program Savage Municipal Supply Well Superfund site: Amherst, N.H., 3 chaps., variously paginated.

Environmental Science and Engineering, Inc., 1997, Final results of vertical profiling program Savage Municipal Supply Well Superfund site: Amherst, N.H., February 1997, 25 p.

Environmental Systems Research Institute, Inc. (ESRI), 1994, Network analysis: Redlands, Calif., 208 p.

Freeze, R.A., and Cherry, J.A., 1979, Groundwater: Englewood Cliffs, N.J., Prentice-Hall, 604 p.

Goode, D.J., and Konikow, L.F., 1990, Apparent dispersion in transient groundwater flow: Water Resources Research, v. 26 , no. 10 , p. 2339-2351.

Guilbeaut, M.A., Cherry, J.A., and Parker, B.L., 1997, Final report, Groundwater and soil sampling at the Savage Well Superfund site, Milford, N.H.: Waterloo, Ontario, University of Waterloo, Department of Earth Sciences, variously paginated.

Guilbeaut, M.A., Cherry, J.A., and Parker, B.L., 1998, Phase 2, Groundwater and soil sampling at the Savage Well Superfund site, Milford, N.H.: Waterloo, Ontario, University of Waterloo, Department of Earth Sciences, variously paginated.

Guilbeaut, M.A., 1999, Suspended DNAPL source zones in three sandy aquifers: Plume anatomy, mass discharge, and sampling scale considerations: Waterloo, Ontario, University of Waterloo, Department of Earth Sciences, Masters thesis, $154 \mathrm{p}$.

Harbaugh, A.W., and McDonald, M.G., 1996a, User's documentation for MODFLOW-96, an update to the U.S. Geological Survey modular finite-difference ground-water flow model: U.S. Geological Survey Open-File Report 96-485, $56 \mathrm{p}$.
Harbaugh, A.W., and McDonald, M.G., 1996b, Programmer's documentation for MODFLOW-96, an update to the U.S. Geological Survey modular finite-difference ground-water flow model: U.S. Geological Survey Open-File Report 96-486, $220 \mathrm{p}$.

Harbaugh, A.W., Banta, E.R., Hill, M.C., and McDonald, M.G., 2000, MODFLOW-2000, The U.S. Geological Survey modular ground-water model-User guide to modularization concepts and the ground-water flow process: U.S. Geological Survey Open-File Report 00-92, 121 p.

Harte, P.T., and Mack, T.J., 1992, Geohydrology of, and simulation of, ground-water flow in the Milford-Souhegan Glacial-Drift aquifer, Milford, New Hampshire: U.S. Geological Survey Water-Resources Investigations Report 91-4177, 90 p.

Harte, P.T., and Willey, R.E., 1997, Effects of historical withdrawals on advective transport of contaminated ground waters in a glacial-drift aquifer, Milford, New Hampshire: U.S. Geological Survey Fact Sheet 162-97, 6 p.

Harte, P.T., Flynn, R.J., Kiah, R.G., Severance, Timothy, Coakley, M.F., 1997, Information on hydrologic and physical properties of water to assess transient hydrology of the Milford-Souhegan Glacial-Drift aquifer, Milford, New Hampshire: U.S. Geological Survey Open-File Report 97-414, 96 p.

Harte, P.T., Flynn, R.J., and Mack, T.J., 1999, Construction and calibration of numerical ground-water flow models of the Milford-Souhegan Glacial Drift aquifer, Milford, New Hampshire: U.S. Geological Survey Open-File Report 99-462, 76 p.

Harte, P.T., Brayton, M.J., Ives, Wayne, Perkins, Sharon, and Brown, Carroll, 2001, Testing and application of waterdiffusion samplers to identify temporal trends in volatileorganic compounds: U.S. Geological Survey Open-File Report 00-196, 91 p.

Harte, P.T., 2004, Simulation of solute transport of tetrachloroethylene in ground water of the glacial-drift aquifer at the Savage Municipal Well Superfund site, Milford, New Hampshire, 1960-2000: U.S. Geological Survey Scientific Investigations Report 2004-5176, 84 p.

Harte, P.T., 2005, Results of a monitoring program of continuous water levels and physical water properties at the OU1 area of the Savage Municipal Well Superfund site, water years 2000-03, Milford, New Hampshire: U.S. Geological Survey Open-File Report 2005-1303, 44 p.

HMM Associates, Inc., 1989, Draft remedial investigation, Savage Well site, Milford, New Hampshire: Concord, Mass., no. 2176 HAZ/2880, 218 p. 
HMM Associates, Inc., 1991, Remedial investigation, Savage Well site, Milford, New Hampshire: Concord, Mass., no. $2176 \mathrm{HAZ} / 4814,800$ p.

Hornberger, G.Z., Konikow, L.F., and Harte, P.T., 2002, Simulating solute transport across horizontal-flow barriers using the MODFLOW Ground-Water Transport Process: U.S. Geological Survey Open-File Report 02-52, 28 p.

Hsieh, P.A., and Freckleton, J.R., 1993, Documentation of a computer program to simulate horizontal-flow barriers using the U.S. Geological Survey's modular three-dimensional finite-difference ground-water flow model: U.S. Geological Survey Open-File Report 92-477, 32 p.

Konikow, L.F., Goode, D.J., and Hornberger, G.Z., 1996, A three-dimensional method of characteristics solute-transport model (MOC3D): U.S. Geological Survey Water-Resources Investigations Report 96-4267, 87 p.

Konikow, L.F., Harte, P.T., and Hornberger, G.Z., 2001, Simulating solute transport across horizontal-flow barriers, Seo, H.S., Poeter, E., Zheng, C., Poeter, O., eds., in MODFLOW 2001 and other modeling odysseys, Internet. Ground Water Modeling Center, Golden, Colo., p. 510-516.

Koteff, Carl, 1970, Surficial geologic map of the Milford quadrangle, Hillsborough County, New Hampshire: U.S. Geological Survey Geologic Quadrangle Map GQ-881, scale 1:62,500.

Lyons, J.B., Bothner, W.A., Moench, R.H., and Thompson, J.B., 1997, Bedrock geologic map of New Hampshire: U.S. Geological Survey State Geologic Map, 2 sheets, scales 1:250,000 and 1:500,000.

McDonald, M.G., and Harbaugh, A.W., 1988, A modular three-dimensional finite-difference ground-water flow model: U.S. Geological Survey Techniques of WaterResources Investigations, book 6, chap. A1, 586 p.

McDonald, M.G., Harbaugh, A.W., Orr, B.R., and Ackerman, D.J., 1991, A method of converting no-flow cells to variable-head cells for the U.S. Geological Survey Modular Finite-Difference Ground-Water Flow Model: U.S. Geological Survey Open-File Report 91-536, 95 p.

New Hampshire Department of Environmental Services, 2003, First five-year review report for Savage Well Municipal Supply Superfund site, OU-1 Milford, Hillsborough County, New Hampshire: Concord, N.H., variously paginated.

Pollock, D.W., 1994, User's guide for MODPATH/MODPATH-PLOT, version 3; A particle tracking post-processing package for MODFLOW, the U.S. Geological Survey finite-difference ground-water flow model: U.S. Geological Survey Open-File Report 94-464, 248 p.

QST Environmental, Inc., 1997, Draft remedial design investigation report: Nashua, N.H., variously paginated.
Randall, A.D., 2001, Hydrogeologic framework of stratifieddrift aquifers in the glaciated northeastern United StatesRegional Aquifer System Analysis-northeastern United States: U.S. Geological Survey Professional Paper 1415-B, 179 p.

Rasmussen, W.C., and Andreason, G.E., 1959, Hydrologic budget of the Beaverdam Creek basin, Maryland: U.S. Geological Survey Water-Supply Paper 1472, 106 p.

Tetra Tech EM, Inc., U.S. Environmental Protection Agency, and Idaho National Engineering and Environmental Laboratory, 2003, Superfund innovative technology evaluation site program summary report: U.S. Environmental Protection Agency Region 1, Contract no. 68-C5-0037, variously paginated.

Trescott, P.C., and Pinder, G.F., and Larson, S.P., 1976, Finitedifference model for aquifer simulation in two dimensions with results of numerical experiments: U.S. Geological Survey Techniques of Water-Resources Investigations, book 7, chap. C1, $116 \mathrm{p}$.

U.S. Environmental Protection Agency, 1999, Use of monitored natural attenuation at Superfund, RCRA corrective action, and underground storage tank sites: Washington, D.C., Publication no. 540/R-99/009, 39 p.

U.S. Environmental Protection Agency, 2000, National water quality inventory-1998 Report: Washington D.C., Report no. EPA-841-F-00-006, variously paginated.

U.S. Environmental Protection Agency, 2001, Draft, Remedial systems evaluation, Savage Municipal Water Supply Superfund site, Milford, N.H.: Edison, N.J., Technology Innovation Office, $27 \mathrm{p}$.

U.S. Filter, Inc., 2004, Annual report of the groundwater remediation progress at the Savage Municipal Water Supply Superfund site, OU-1, The OK Tool site, July 2002 through June 2003: State College, Penn., U.S. Filter Engineering and Construction, variously paginated.

U.S. Filter, Inc., 2005, Annual report of the groundwater remediation progress at the Savage Municipal Water Supply Superfund site, OU-1, The OK Tool site, July 2003 through June 2004: State College, Penn., U.S. Filter Engineering and Construction, variously paginated.

Winston, R.B., 2000, Graphical user interface for MODFLOW, version 4: U.S. Geological Survey Open-File Report 00-315, 27 p.

Zheng, Chunmiao, and Bennett, G.D., 1995, Applied contaminant transport modeling: New York, Van Nostrand Reinhold, $440 \mathrm{p}$. 
Appendixes 1-4 
Appendix 1. Information on wells and vertical profile points, Savage Municipal Well Superfund site, Milford, N.H.

[All units in feet; Horizontal datum based on 2,000-foot grid New Hampshire State Planar coordinate system North American Datum 1983; vertical datum based on feet above National Geodetic Vertical Datum 1929; depth in feet below land surface; well name descriptions on page ix in this report; location of some wells are on figure 2; some wells not shown on figure 2; --, no data; wells are sorted alphabetically. Description of measurement point: TSC, top of steel casing; TPVC, top of polyvinyl chloride pipe; shelter, top of shelter floor; SG, staff gage; SG2, second staff gage; SG3, third staff gage; SG4, fourth staff gage; TCONC, top of concrete; RIM, rim of manhole cover; BOLT HEAD, top of bolt; WELLCVR, well cover; TINRSC, top of inner steel casing; AHPUMP, air line reading at pump; top rebar, top of rebar pipe; USGS disc, top of U.S. Geological Survey disc; VENT, vent hole at pump; TOC, top of casing; PWMC, production well metal casing]

\begin{tabular}{|c|c|c|c|c|c|c|c|c|c|c|}
\hline $\begin{array}{c}\text { Well } \\
\text { number }\end{array}$ & Well name & Easting & Northing & $\begin{array}{l}\text { Altitude of } \\
\text { measure- } \\
\text { ment point }\end{array}$ & $\begin{array}{c}\text { Description of } \\
\text { measurement } \\
\text { point }\end{array}$ & $\begin{array}{c}\text { Altitude } \\
\text { of land } \\
\text { surface }\end{array}$ & $\begin{array}{c}\text { Top of } \\
\text { opening } \\
\text { below } \\
\text { land } \\
\text { surface }\end{array}$ & $\begin{array}{c}\text { Bottom of } \\
\text { opening } \\
\text { below } \\
\text { land } \\
\text { surface }\end{array}$ & $\begin{array}{c}\text { Depth to } \\
\text { refusal } \\
\text { below } \\
\text { land } \\
\text { surface }\end{array}$ & $\begin{array}{c}\text { Depth to } \\
\text { bedrock } \\
\text { below } \\
\text { land } \\
\text { surface }\end{array}$ \\
\hline 106 & -- & 969943.6 & 115997.7 & -- & -- & -- & -- & -- & -- & -- \\
\hline 105 & -- & 972221.4 & 119573.1 & -- & -- & -- & -- & -- & -- & -- \\
\hline 120 & -- & 974826.1 & 117243.0 & -- & -- & -- & -- & -- & -- & -- \\
\hline 622 & -- & 974829.0 & 124902.3 & 272.94 & TPVC & -- & -- & -- & -- & -- \\
\hline 119 & -- & 975143.4 & 117530.1 & -- & -- & -- & -- & -- & -- & -- \\
\hline 66 & -- & 975354.0 & 124548.9 & -- & -- & 270.0 & -- & -- & -- & -- \\
\hline 64 & -- & 976086.6 & 124426.6 & -- & -- & 265.3 & -- & -- & -- & -- \\
\hline 69 & -- & 976146.7 & 124676.0 & -- & -- & 266.3 & -- & -- & -- & -- \\
\hline 71 & -- & 976275.6 & 124553.6 & -- & -- & 264.0 & -- & -- & -- & -- \\
\hline 70 & -- & 976282.6 & 124669.8 & -- & -- & 264.1 & -- & -- & -- & -- \\
\hline 364 & -- & 976295.6 & 125521.0 & 264.93 & -- & 262.5 & -- & -- & -- & -- \\
\hline 121 & -- & 976507.9 & 117660.4 & -- & -- & -- & -- & -- & -- & -- \\
\hline 111 & -- & 976843.4 & 115878.6 & -- & -- & -- & -- & -- & -- & -- \\
\hline 117 & -- & 977035.0 & 115723.0 & -- & -- & -- & -- & -- & -- & -- \\
\hline 67 & -- & 979957.1 & 124233.7 & -- & -- & 250.0 & -- & -- & -- & -- \\
\hline 82 & -- & 982214.8 & 125347.6 & -- & -- & 240.0 & -- & -- & -- & 23 \\
\hline 107 & -- & 982412.5 & 131350.5 & -- & -- & 349.2 & -- & -- & -- & -- \\
\hline 109 & -- & 982510.9 & 130710.2 & -- & -- & 349.3 & -- & -- & -- & -- \\
\hline 192 & -- & 984005.2 & 123305.5 & -- & -- & 266.7 & -- & -- & -- & 12 \\
\hline 84 & \#226inSurv & 975999.6 & 127234.7 & 262.51 & TSC & 261.7 & 51 & 66 & -- & 60 \\
\hline 376 & 2ftHitchPW1 & 975620.1 & 124005.9 & -- & -- & -- & -- & -- & -- & -- \\
\hline 377 & $3 \mathrm{ftHitchPW} 1$ & 975608.9 & 124010.1 & -- & -- & -- & -- & -- & -- & -- \\
\hline 412 & A01 & 975851.3 & 124173.6 & -- & -- & -- & -- & -- & -- & -- \\
\hline 413 & A02 & 975826.8 & 124285.6 & -- & -- & -- & -- & -- & -- & -- \\
\hline 414 & A03 & 975766.3 & 124433.6 & -- & -- & -- & -- & -- & -- & -- \\
\hline
\end{tabular}


Appendix 1. Information on wells and vertical profile points, Savage Municipal Well Superfund site, Milford, N.H.-Continued

[All units in feet; Horizontal datum based on 2,000-foot grid New Hampshire State Planar coordinate system North American Datum 1983; vertical datum based on feet above National Geodetic Vertical Datum 1929; depth in feet below land surface; well name descriptions on page ix in this report; location of some wells are on figure 2; some wells not shown on figure 2; --, no data; wells are sorted alphabetically. Description of measurement point: TSC, top of steel casing; TPVC, top of polyvinyl chloride pipe; shelter, top of shelter floor; SG, staff gage; SG2, second staff gage; SG3, third staff gage; SG4, fourth staff gage; TCONC, top of concrete; RIM, rim of manhole cover; BOLT HEAD, top of bolt; WELLCVR, well cover; TINRSC, top of inner steel casing; AHPUMP, air line reading at pump; top rebar, top of rebar pipe; USGS disc, top of U.S. Geological Survey disc; VENT, vent hole at pump; TOC, top of casing; PWMC, production well metal casing]

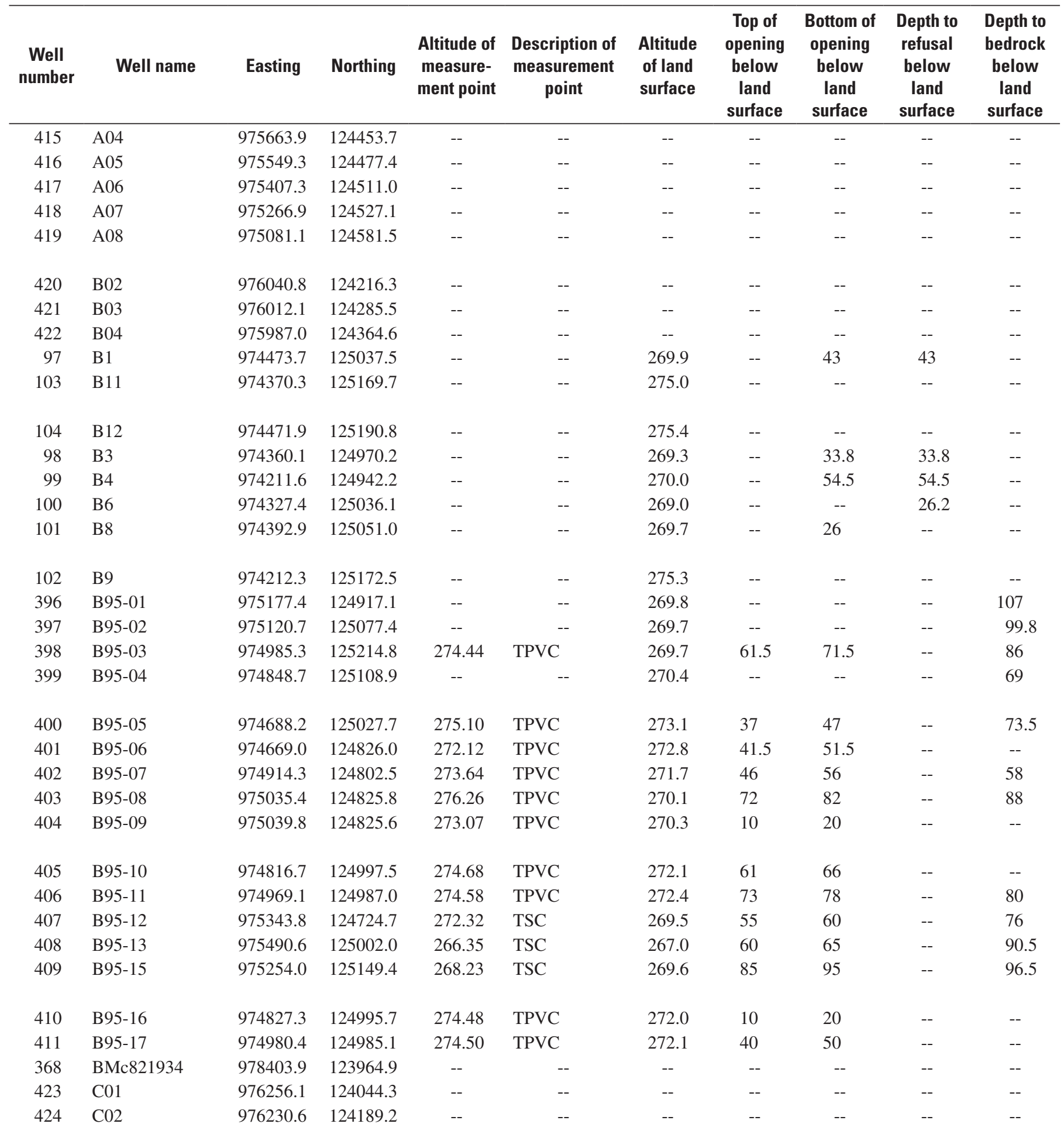


Appendix 1. Information on wells and vertical profile points, Savage Municipal Well Superfund site, Milford, N.H.-Continued

[All units in feet; Horizontal datum based on 2,000-foot grid New Hampshire State Planar coordinate system North American Datum 1983; vertical datum based on feet above National Geodetic Vertical Datum 1929; depth in feet below land surface; well name descriptions on page ix in this report; location of some wells are on figure 2; some wells not shown on figure 2; --, no data; wells are sorted alphabetically. Description of measurement point: TSC, top of steel casing; TPVC, top of polyvinyl chloride pipe; shelter, top of shelter floor; SG, staff gage; SG2, second staff gage; SG3, third staff gage; SG4, fourth staff gage; TCONC, top of concrete; RIM, rim of manhole cover; BOLT HEAD, top of bolt; WELLCVR, well cover; TINRSC, top of inner steel casing; AHPUMP, air line reading at pump; top rebar, top of rebar pipe; USGS disc, top of U.S. Geological Survey disc; VENT, vent hole at pump; TOC, top of casing; PWMC, production well metal casing]

\begin{tabular}{|c|c|c|c|c|c|c|c|c|c|c|}
\hline $\begin{array}{c}\text { Well } \\
\text { number }\end{array}$ & Well name & Easting & Northing & $\begin{array}{l}\text { Altitude of } \\
\text { measure- } \\
\text { ment point }\end{array}$ & $\begin{array}{c}\text { Description of } \\
\text { measurement } \\
\text { point }\end{array}$ & $\begin{array}{l}\text { Altitude } \\
\text { of land } \\
\text { surface }\end{array}$ & $\begin{array}{c}\text { Top of } \\
\text { opening } \\
\text { below } \\
\text { land } \\
\text { surface }\end{array}$ & $\begin{array}{c}\text { Bottom of } \\
\text { opening } \\
\text { below } \\
\text { land } \\
\text { surface }\end{array}$ & $\begin{array}{c}\text { Depth to } \\
\text { refusal } \\
\text { below } \\
\text { land } \\
\text { surface }\end{array}$ & $\begin{array}{c}\text { Depth to } \\
\text { bedrock } \\
\text { below } \\
\text { land } \\
\text { surface }\end{array}$ \\
\hline 425 & $\mathrm{C} 03$ & 976190.0 & 124344.9 & -- & -- & -- & -- & -- & -- & -- \\
\hline 426 & $\mathrm{C} 05$ & 976169.6 & 124514.3 & -- & -- & -- & -- & -- & -- & -- \\
\hline 427 & $\mathrm{C} 06$ & 976100.7 & 124649.9 & -- & -- & -- & -- & -- & -- & -- \\
\hline 428 & $\mathrm{C} 07$ & 976004.9 & 124868.5 & -- & -- & -- & -- & -- & -- & -- \\
\hline 429 & $\mathrm{C} 08$ & 975946.1 & 125071.3 & -- & -- & -- & -- & -- & -- & -- \\
\hline 430 & C09 & 975816.7 & 125270.9 & -- & -- & -- & -- & -- & -- & -- \\
\hline 431 & $\mathrm{C} 10$ & 975918.7 & 125457.1 & -- & -- & -- & -- & -- & -- & -- \\
\hline 432 & C11 & 975949.1 & 125669.0 & -- & -- & -- & -- & -- & -- & -- \\
\hline 249 & Cassarino & 975491.4 & 127480.1 & -- & -- & 267.9 & -- & 12.5 & -- & -- \\
\hline 433 & D01 & 977181.0 & 123965.6 & -- & -- & -- & -- & -- & -- & -- \\
\hline 434 & D02 & 977047.1 & 124350.6 & -- & -- & -- & -- & -- & -- & -- \\
\hline 435 & D03 & 976969.2 & 124522.3 & -- & -- & -- & -- & -- & -- & -- \\
\hline 436 & D04 & 976926.2 & 124651.9 & -- & -- & -- & -- & -- & -- & -- \\
\hline 437 & D05 & 976816.8 & 124924.6 & -- & -- & -- & -- & -- & -- & -- \\
\hline 438 & D06 & 976751.4 & 125088.4 & -- & -- & -- & -- & -- & -- & -- \\
\hline 439 & D07 & 976690.2 & 125251.6 & -- & -- & -- & -- & -- & -- & -- \\
\hline 440 & D08 & 976551.7 & 125609.5 & -- & -- & -- & -- & -- & -- & -- \\
\hline 441 & D10 & 976363.6 & 126104.4 & -- & -- & -- & -- & -- & -- & -- \\
\hline 442 & D11 & 976033.8 & 126246.6 & -- & -- & -- & -- & -- & -- & -- \\
\hline 443 & D21 & 976616.5 & 125429.2 & -- & -- & -- & -- & -- & -- & -- \\
\hline 444 & E01 & 978145.9 & 124145.0 & -- & -- & -- & -- & -- & -- & -- \\
\hline 445 & E02 & 978218.4 & 124455.1 & -- & -- & -- & -- & -- & -- & -- \\
\hline 446 & E03 & 978112.3 & 124704.9 & -- & -- & -- & -- & -- & -- & -- \\
\hline 447 & E04 & 978005.2 & 124898.1 & -- & -- & -- & -- & -- & -- & -- \\
\hline 448 & E05 & 977928.1 & 125053.3 & -- & -- & -- & -- & -- & -- & -- \\
\hline 449 & E06 & 977852.8 & 125221.0 & -- & -- & -- & -- & -- & -- & -- \\
\hline 450 & E07 & 977768.1 & 125414.4 & -- & -- & -- & -- & -- & -- & -- \\
\hline 451 & E08 & 977698.5 & 125714.6 & -- & -- & -- & -- & -- & -- & -- \\
\hline 452 & E09 & 977575.0 & 126168.8 & -- & -- & -- & -- & -- & -- & -- \\
\hline 453 & E10 & 977468.0 & 126394.4 & -- & -- & -- & -- & -- & -- & -- \\
\hline 454 & E11 & 977542.1 & 126522.2 & -- & -- & -- & -- & -- & -- & -- \\
\hline 599 & ESE-EWA & 977303.1 & 125074.5 & 260.79 & -- & 257.5 & 36.4 & 51.7 & -- & -- \\
\hline 605 & ESE-EWB & 979262.3 & 126082.9 & 256.10 & -- & 254.0 & 38.9 & 56 & -- & -- \\
\hline 600 & ESE-PZA1 & 977301.3 & 125087.4 & 260.06 & -- & 257.4 & 10 & 15 & -- & -- \\
\hline 601 & ESE-PZA2 & 977317.0 & 125042.6 & 260.14 & -- & 257.5 & 10 & 15 & -- & -- \\
\hline
\end{tabular}


Appendix 1. Information on wells and vertical profile points, Savage Municipal Well Superfund site, Milford, N.H.—Continued

[All units in feet; Horizontal datum based on 2,000-foot grid New Hampshire State Planar coordinate system North American Datum 1983; vertical datum based on feet above National Geodetic Vertical Datum 1929; depth in feet below land surface; well name descriptions on page ix in this report; location of some wells are on figure 2; some wells not shown on figure 2; --, no data; wells are sorted alphabetically. Description of measurement point: TSC, top of steel casing; TPVC, top of polyvinyl chloride pipe; shelter, top of shelter floor; SG, staff gage; SG2, second staff gage; SG3, third staff gage; SG4, fourth staff gage; TCONC, top of concrete; RIM, rim of manhole cover; BOLT HEAD, top of bolt; WELLCVR, well cover; TINRSC, top of inner steel casing; AHPUMP, air line reading at pump; top rebar, top of rebar pipe; USGS disc, top of U.S. Geological Survey disc; VENT, vent hole at pump; TOC, top of casing; PWMC, production well metal casing]

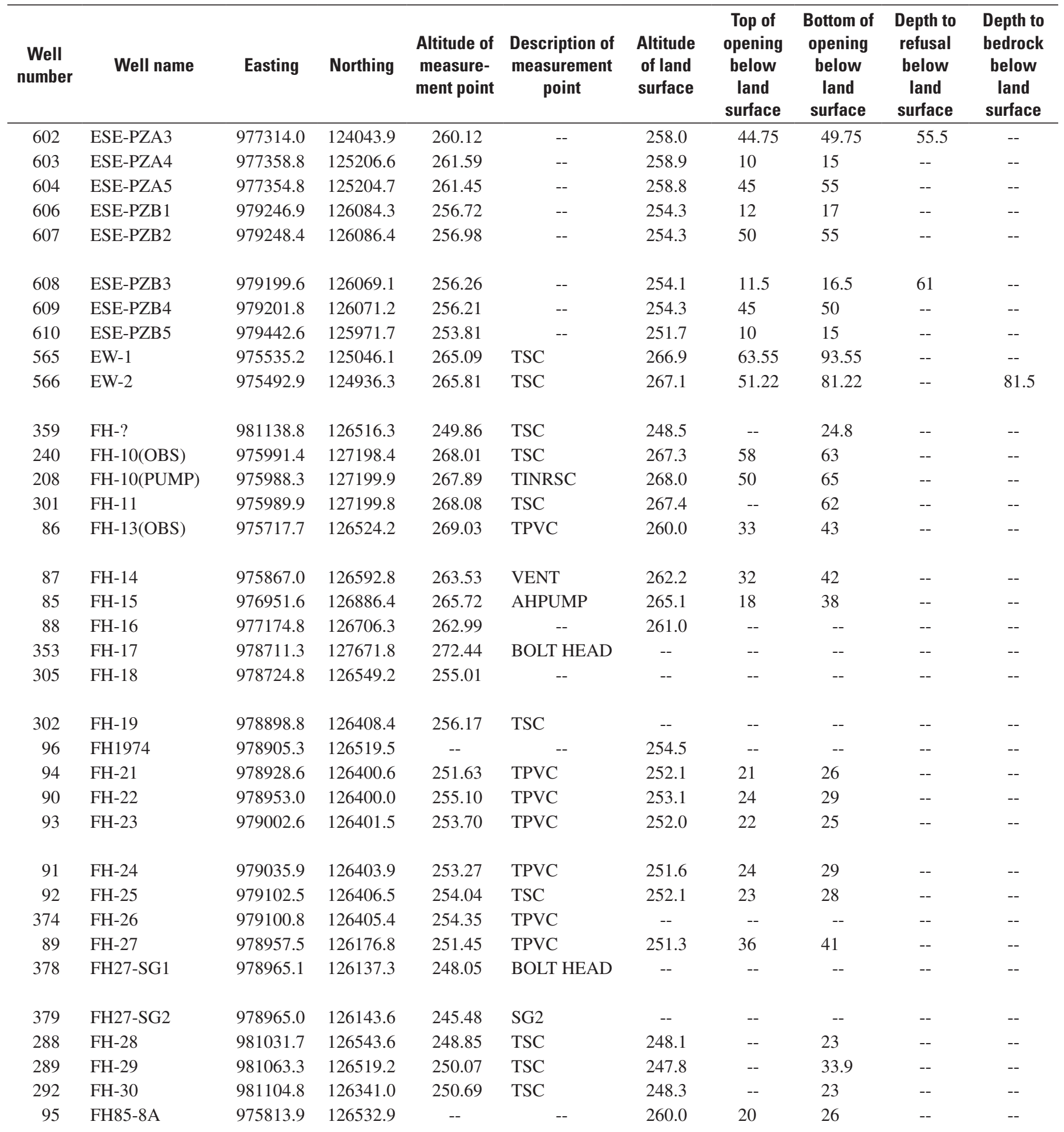


Appendix 1. Information on wells and vertical profile points, Savage Municipal Well Superfund site, Milford, N.H.—Continued

[All units in feet; Horizontal datum based on 2,000-foot grid New Hampshire State Planar coordinate system North American Datum 1983; vertical datum based on feet above National Geodetic Vertical Datum 1929; depth in feet below land surface; well name descriptions on page ix in this report; location of some wells are on figure 2; some wells not shown on figure 2; --, no data; wells are sorted alphabetically. Description of measurement point: TSC, top of steel casing; TPVC, top of polyvinyl chloride pipe; shelter, top of shelter floor; SG, staff gage; SG2, second staff gage; SG3, third staff gage; SG4, fourth staff gage; TCONC, top of concrete; RIM, rim of manhole cover; BOLT HEAD, top of bolt; WELLCVR, well cover; TINRSC, top of inner steel casing; AHPUMP, air line reading at pump; top rebar, top of rebar pipe; USGS disc, top of U.S. Geological Survey disc; VENT, vent hole at pump; TOC, top of casing; PWMC, production well metal casing]

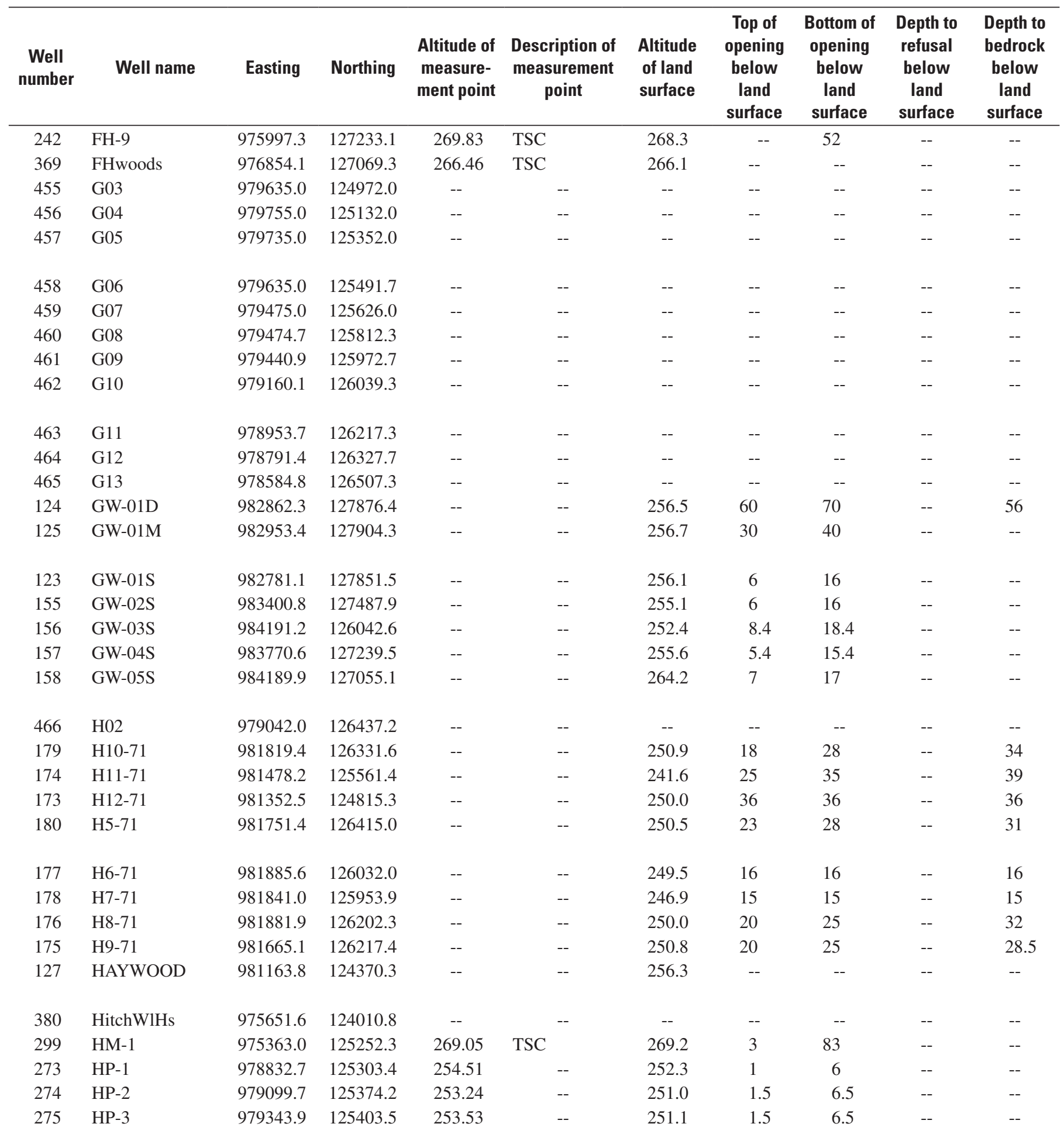


Appendix 1. Information on wells and vertical profile points, Savage Municipal Well Superfund site, Milford, N.H.—Continued

[All units in feet; Horizontal datum based on 2,000-foot grid New Hampshire State Planar coordinate system North American Datum 1983; vertical datum based on feet above National Geodetic Vertical Datum 1929; depth in feet below land surface; well name descriptions on page ix in this report; location of some wells are on figure 2; some wells not shown on figure 2; --, no data; wells are sorted alphabetically. Description of measurement point: TSC, top of steel casing; TPVC, top of polyvinyl chloride pipe; shelter, top of shelter floor; SG, staff gage; SG2, second staff gage; SG3, third staff gage; SG4, fourth staff gage; TCONC, top of concrete; RIM, rim of manhole cover; BOLT HEAD, top of bolt; WELLCVR, well cover; TINRSC, top of inner steel casing; AHPUMP, air line reading at pump; top rebar, top of rebar pipe; USGS disc, top of U.S. Geological Survey disc; VENT, vent hole at pump; TOC, top of casing; PWMC, production well metal casing]

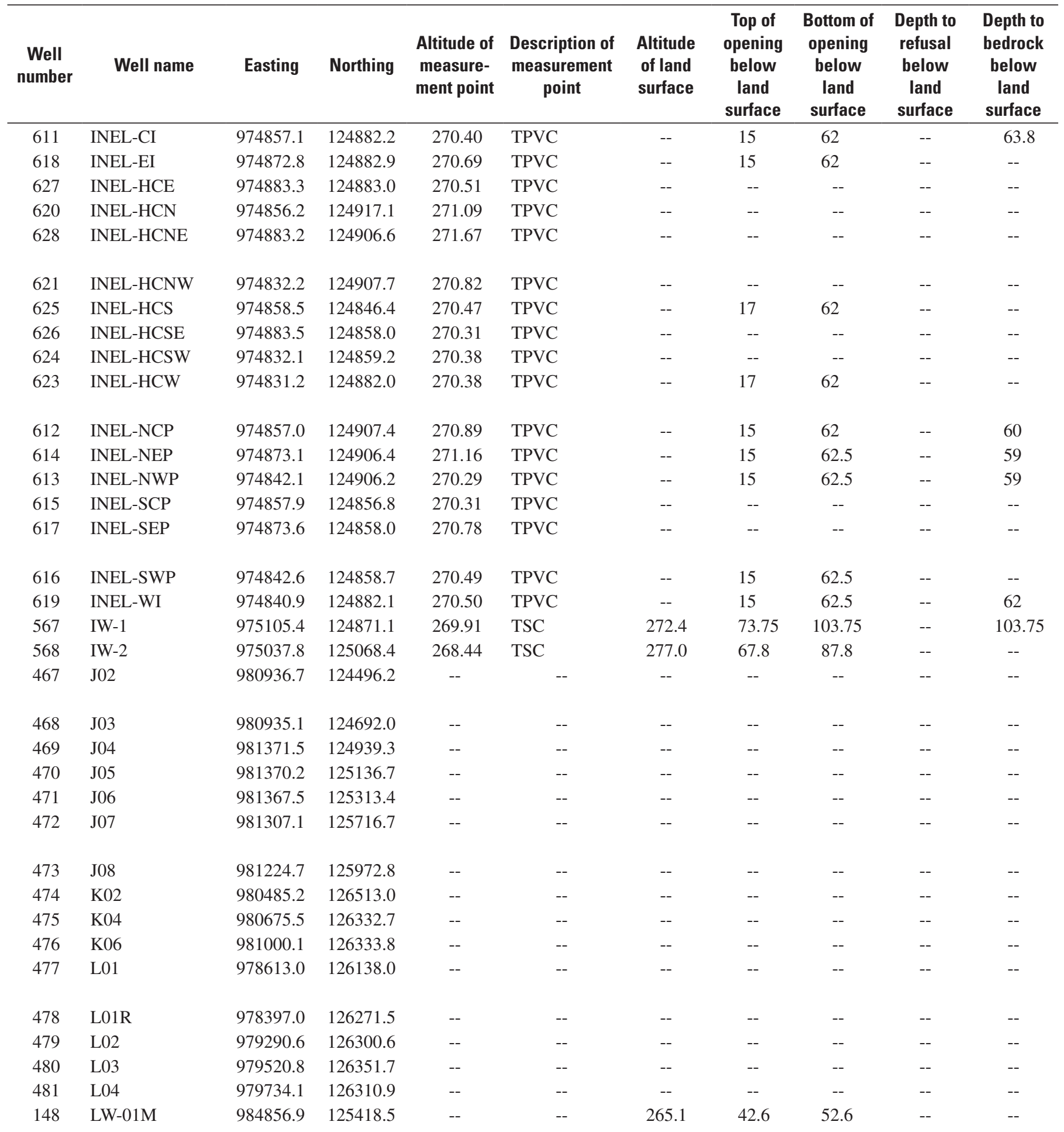


Appendix 1. Information on wells and vertical profile points, Savage Municipal Well Superfund site, Milford, N.H.—Continued

[All units in feet; Horizontal datum based on 2,000-foot grid New Hampshire State Planar coordinate system North American Datum 1983; vertical datum based on feet above National Geodetic Vertical Datum 1929; depth in feet below land surface; well name descriptions on page ix in this report; location of some wells are on figure 2; some wells not shown on figure 2; --, no data; wells are sorted alphabetically. Description of measurement point: TSC, top of steel casing; TPVC, top of polyvinyl chloride pipe; shelter, top of shelter floor; SG, staff gage; SG2, second staff gage; SG3, third staff gage; SG4, fourth staff gage; TCONC, top of concrete; RIM, rim of manhole cover; BOLT HEAD, top of bolt; WELLCVR, well cover; TINRSC, top of inner steel casing; AHPUMP, air line reading at pump; top rebar, top of rebar pipe; USGS disc, top of U.S. Geological Survey disc; VENT, vent hole at pump; TOC, top of casing; PWMC, production well metal casing]

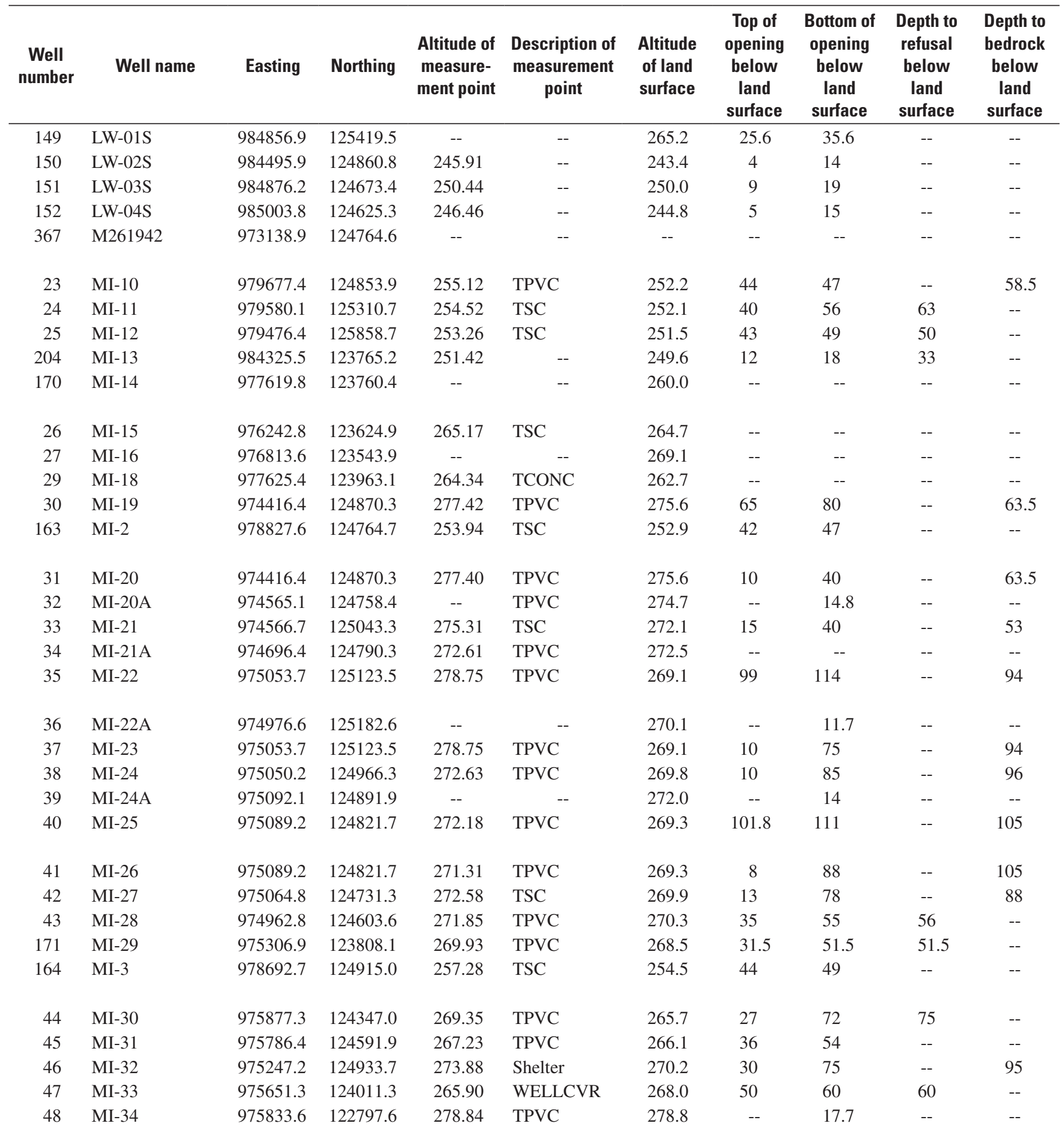


Appendix 1. Information on wells and vertical profile points, Savage Municipal Well Superfund site, Milford, N.H.—Continued

[All units in feet; Horizontal datum based on 2,000-foot grid New Hampshire State Planar coordinate system North American Datum 1983; vertical datum based on feet above National Geodetic Vertical Datum 1929; depth in feet below land surface; well name descriptions on page ix in this report; location of some wells are on figure 2; some wells not shown on figure 2; --, no data; wells are sorted alphabetically. Description of measurement point: TSC, top of steel casing; TPVC, top of polyvinyl chloride pipe; shelter, top of shelter floor; SG, staff gage; SG2, second staff gage; SG3, third staff gage; SG4, fourth staff gage; TCONC, top of concrete; RIM, rim of manhole cover; BOLT HEAD, top of bolt; WELLCVR, well cover; TINRSC, top of inner steel casing; AHPUMP, air line reading at pump; top rebar, top of rebar pipe; USGS disc, top of U.S. Geological Survey disc; VENT, vent hole at pump; TOC, top of casing; PWMC, production well metal casing]

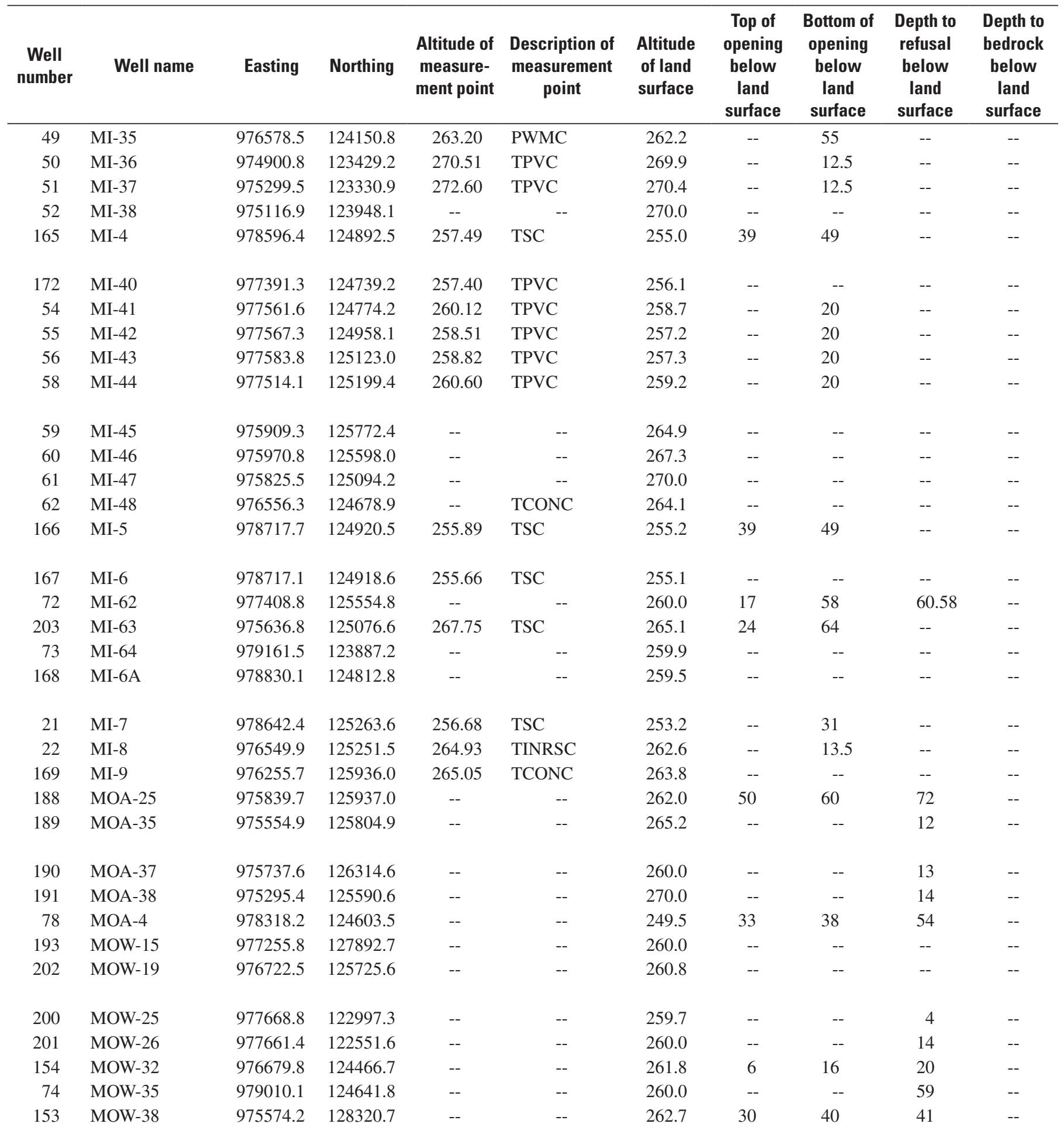


Appendix 1. Information on wells and vertical profile points, Savage Municipal Well Superfund site, Milford, N.H.—Continued

[All units in feet; Horizontal datum based on 2,000-foot grid New Hampshire State Planar coordinate system North American Datum 1983; vertical datum based on feet above National Geodetic Vertical Datum 1929; depth in feet below land surface; well name descriptions on page ix in this report; location of some wells are on figure 2; some wells not shown on figure 2; --, no data; wells are sorted alphabetically. Description of measurement point: TSC, top of steel casing; TPVC, top of polyvinyl chloride pipe; shelter, top of shelter floor; SG, staff gage; SG2, second staff gage; SG3, third staff gage; SG4, fourth staff gage; TCONC, top of concrete; RIM, rim of manhole cover; BOLT HEAD, top of bolt; WELLCVR, well cover; TINRSC, top of inner steel casing; AHPUMP, air line reading at pump; top rebar, top of rebar pipe; USGS disc, top of U.S. Geological Survey disc; VENT, vent hole at pump; TOC, top of casing; PWMC, production well metal casing]

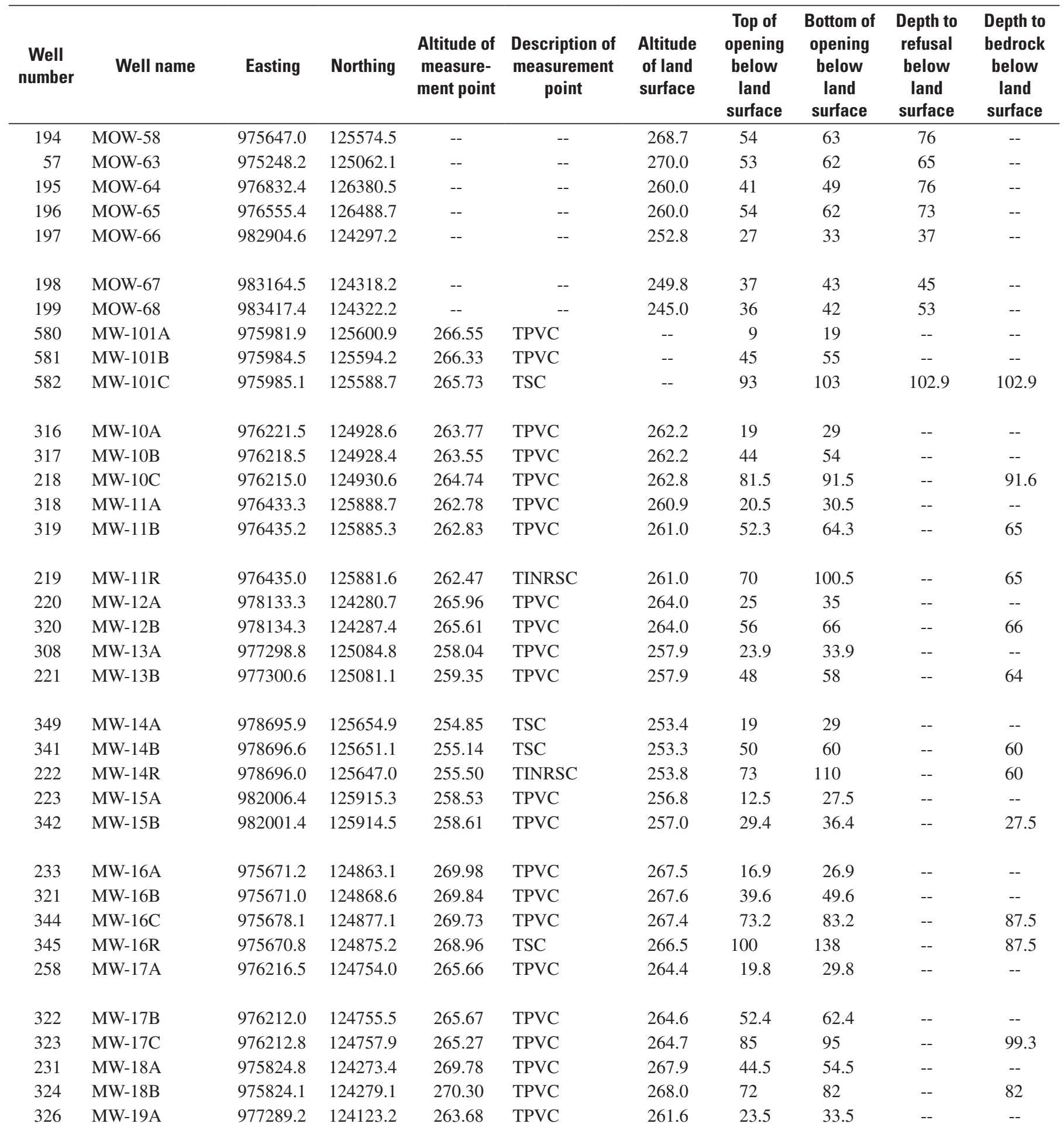


Appendix 1. Information on wells and vertical profile points, Savage Municipal Well Superfund site, Milford, N.H.-Continued

[All units in feet; Horizontal datum based on 2,000-foot grid New Hampshire State Planar coordinate system North American Datum 1983; vertical datum based on feet above National Geodetic Vertical Datum 1929; depth in feet below land surface; well name descriptions on page ix in this report; location of some wells are on figure 2; some wells not shown on figure 2; --, no data; wells are sorted alphabetically. Description of measurement point: TSC, top of steel casing; TPVC, top of polyvinyl chloride pipe; shelter, top of shelter floor; SG, staff gage; SG2, second staff gage; SG3, third staff gage; SG4, fourth staff gage; TCONC, top of concrete; RIM, rim of manhole cover; BOLT HEAD, top of bolt; WELLCVR, well cover; TINRSC, top of inner steel casing; AHPUMP, air line reading at pump; top rebar, top of rebar pipe; USGS disc, top of U.S. Geological Survey disc; VENT, vent hole at pump; TOC, top of casing; PWMC, production well metal casing]

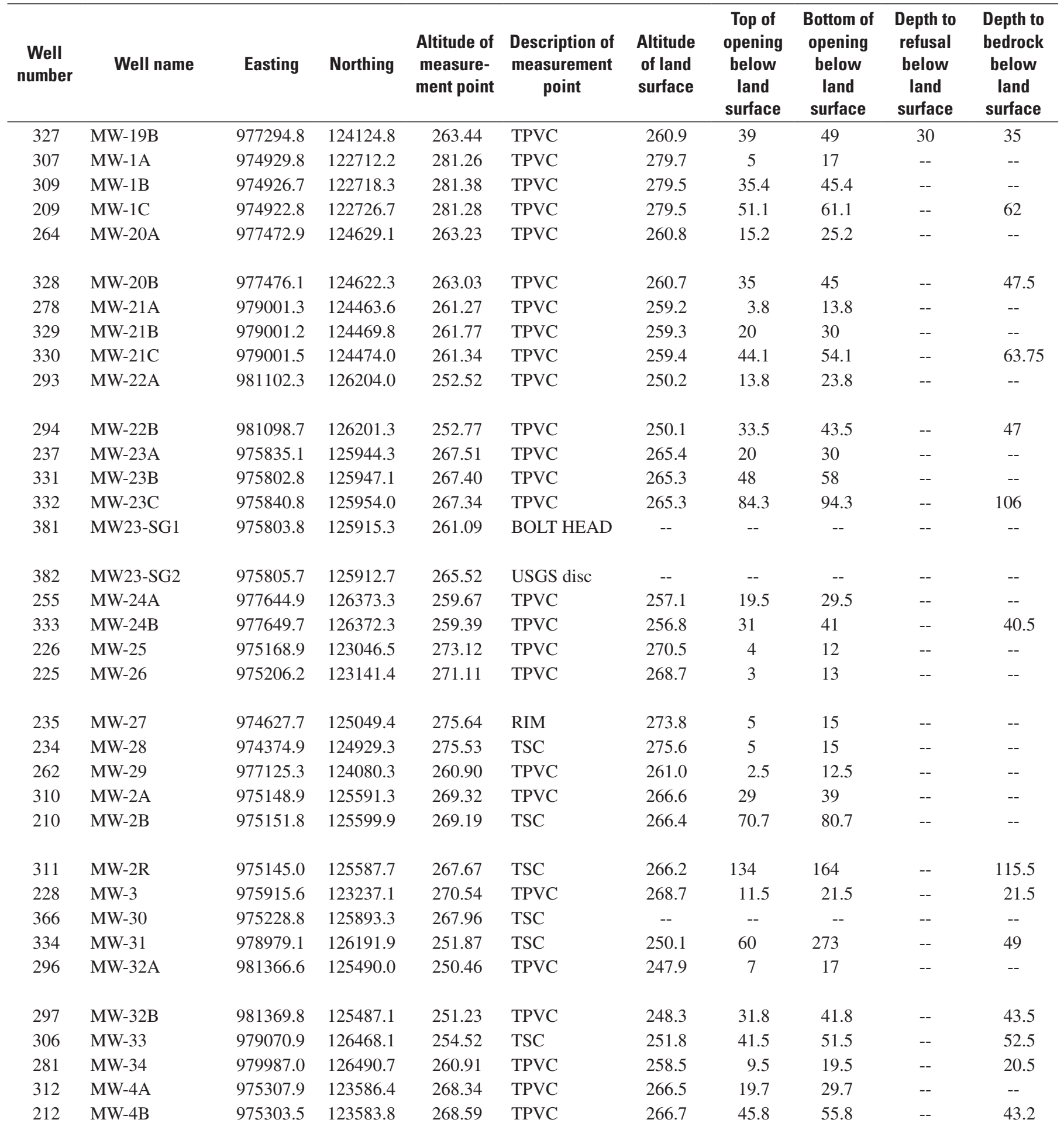


Appendix 1. Information on wells and vertical profile points, Savage Municipal Well Superfund site, Milford, N.H.-Continued

[All units in feet; Horizontal datum based on 2,000-foot grid New Hampshire State Planar coordinate system North American Datum 1983; vertical datum based on feet above National Geodetic Vertical Datum 1929; depth in feet below land surface; well name descriptions on page ix in this report; location of some wells are on figure 2; some wells not shown on figure 2; --, no data; wells are sorted alphabetically. Description of measurement point: TSC, top of steel casing; TPVC, top of polyvinyl chloride pipe; shelter, top of shelter floor; SG, staff gage; SG2, second staff gage; SG3, third staff gage; SG4, fourth staff gage; TCONC, top of concrete; RIM, rim of manhole cover; BOLT HEAD, top of bolt; WELLCVR, well cover; TINRSC, top of inner steel casing; AHPUMP, air line reading at pump; top rebar, top of rebar pipe; USGS disc, top of U.S. Geological Survey disc; VENT, vent hole at pump; TOC, top of casing; PWMC, production well metal casing]

\begin{tabular}{|c|c|c|c|c|c|c|c|c|c|c|}
\hline $\begin{array}{c}\text { Well } \\
\text { number }\end{array}$ & Well name & Easting & Northing & $\begin{array}{c}\text { Altitude of } \\
\text { measure- } \\
\text { ment point }\end{array}$ & $\begin{array}{c}\text { Description of } \\
\text { measurement } \\
\text { point }\end{array}$ & $\begin{array}{c}\text { Altitude } \\
\text { of land } \\
\text { surface }\end{array}$ & $\begin{array}{c}\text { Top of } \\
\text { opening } \\
\text { below } \\
\text { land } \\
\text { surface }\end{array}$ & $\begin{array}{c}\text { Bottom of } \\
\text { opening } \\
\text { below } \\
\text { land } \\
\text { surface }\end{array}$ & $\begin{array}{c}\text { Depth to } \\
\text { refusal } \\
\text { below } \\
\text { land } \\
\text { surface }\end{array}$ & $\begin{array}{c}\text { Depth to } \\
\text { bedrock } \\
\text { below } \\
\text { land } \\
\text { surface }\end{array}$ \\
\hline 347 & MW-4R & 975299.9 & 123581.5 & 268.47 & TSC & 266.4 & 64 & 98 & -- & 45 \\
\hline 313 & MW-5A & 975414.6 & 123981.8 & 269.71 & TPVC & 267.6 & 28 & 38 & -- & -- \\
\hline 214 & MW-6B & 975521.2 & 124486.8 & 268.95 & TPVC & 267.1 & 56.8 & 66.8 & -- & 69.4 \\
\hline 314 & MW-7A & 976267.6 & 123912.6 & 264.40 & TPVC & 262.3 & 3.2 & 13.2 & -- & -- \\
\hline 215 & MW-7B & 976263.3 & 123908.4 & 264.29 & TPVC & 262.5 & 45.6 & 55.6 & -- & 58.6 \\
\hline 315 & MW-8A & 976511.8 & 124151.8 & 263.91 & TPVC & 262.0 & 4.5 & 16.5 & -- & -- \\
\hline 217 & MW-9C & 976503.3 & 124473.6 & 268.09 & TPVC & 266.3 & 79 & 90 & -- & 94 \\
\hline 482 & N01 & 979147.8 & 126556.0 & -- & -- & -- & -- & -- & -- & -- \\
\hline 483 & N02 & 979767.2 & 126623.0 & -- & -- & -- & -- & -- & -- & -- \\
\hline 375 & nearFH19 & 978900.7 & 126413.0 & -- & -- & -- & -- & -- & -- & -- \\
\hline 484 & P01 & 981838.2 & 124649.8 & -- & -- & -- & -- & -- & -- & -- \\
\hline 485 & P02 & 981887.1 & 125105.9 & -- & -- & -- & -- & -- & -- & -- \\
\hline 65 & P-03 & 976979.6 & 124880.4 & 263.27 & TSC & 261.3 & -- & -- & -- & -- \\
\hline 335 & P-1 & 974088.3 & 124847.5 & 279.26 & Shelter & 276.6 & 13.9 & 14.9 & -- & -- \\
\hline 276 & P-10 & 979466.8 & 125859.0 & 252.70 & -- & 250.4 & 7.5 & 8.5 & -- & -- \\
\hline 280 & P-16 & 979986.6 & 126500.0 & 260.43 & TPVC & 258.3 & 12 & 13 & -- & -- \\
\hline 282 & $\mathrm{P}-17 \mathrm{~A}$ & 980125.1 & 126109.1 & 252.54 & -- & 250.6 & 8 & 9 & -- & -- \\
\hline 283 & P-17B & 980124.1 & 126110.1 & 253.66 & -- & 252.6 & 12 & 13 & -- & -- \\
\hline 383 & P1-SG1 & 974066.3 & 124879.1 & 268.91 & BOLT HEAD & -- & -- & -- & -- & -- \\
\hline 384 & P1-SG2 & 974066.9 & 124878.4 & 271.89 & BOLT HEAD & -- & -- & -- & -- & -- \\
\hline 336 & P-2 & 975100.9 & 125281.9 & 271.79 & Shelter & 268.6 & 17 & 18 & -- & -- \\
\hline 385 & P2-SG1 & 975037.3 & 125304.6 & 262.62 & BOLT HEAD & -- & -- & -- & -- & -- \\
\hline 386 & P2-SG2 & 975040.9 & 125298.9 & 260.11 & $\mathrm{SG} 2$ & -- & -- & -- & -- & -- \\
\hline 387 & P2-SG3 & 975043.9 & 125294.6 & 260.11 & SG3 & -- & -- & -- & -- & -- \\
\hline 388 & P2-SG4 & 975045.6 & 125284.0 & 260.11 & SG4 & -- & -- & -- & -- & -- \\
\hline
\end{tabular}


Appendix 1. Information on wells and vertical profile points, Savage Municipal Well Superfund site, Milford, N.H.-Continued

[All units in feet; Horizontal datum based on 2,000-foot grid New Hampshire State Planar coordinate system North American Datum 1983; vertical datum based on feet above National Geodetic Vertical Datum 1929; depth in feet below land surface; well name descriptions on page ix in this report; location of some wells are on figure 2; some wells not shown on figure 2; --, no data; wells are sorted alphabetically. Description of measurement point: TSC, top of steel casing; TPVC, top of polyvinyl chloride pipe; shelter, top of shelter floor; SG, staff gage; SG2, second staff gage; SG3, third staff gage; SG4, fourth staff gage; TCONC, top of concrete; RIM, rim of manhole cover; BOLT HEAD, top of bolt; WELLCVR, well cover; TINRSC, top of inner steel casing; AHPUMP, air line reading at pump; top rebar, top of rebar pipe; USGS disc, top of U.S. Geological Survey disc; VENT, vent hole at pump; TOC, top of casing; PWMC, production well metal casing]

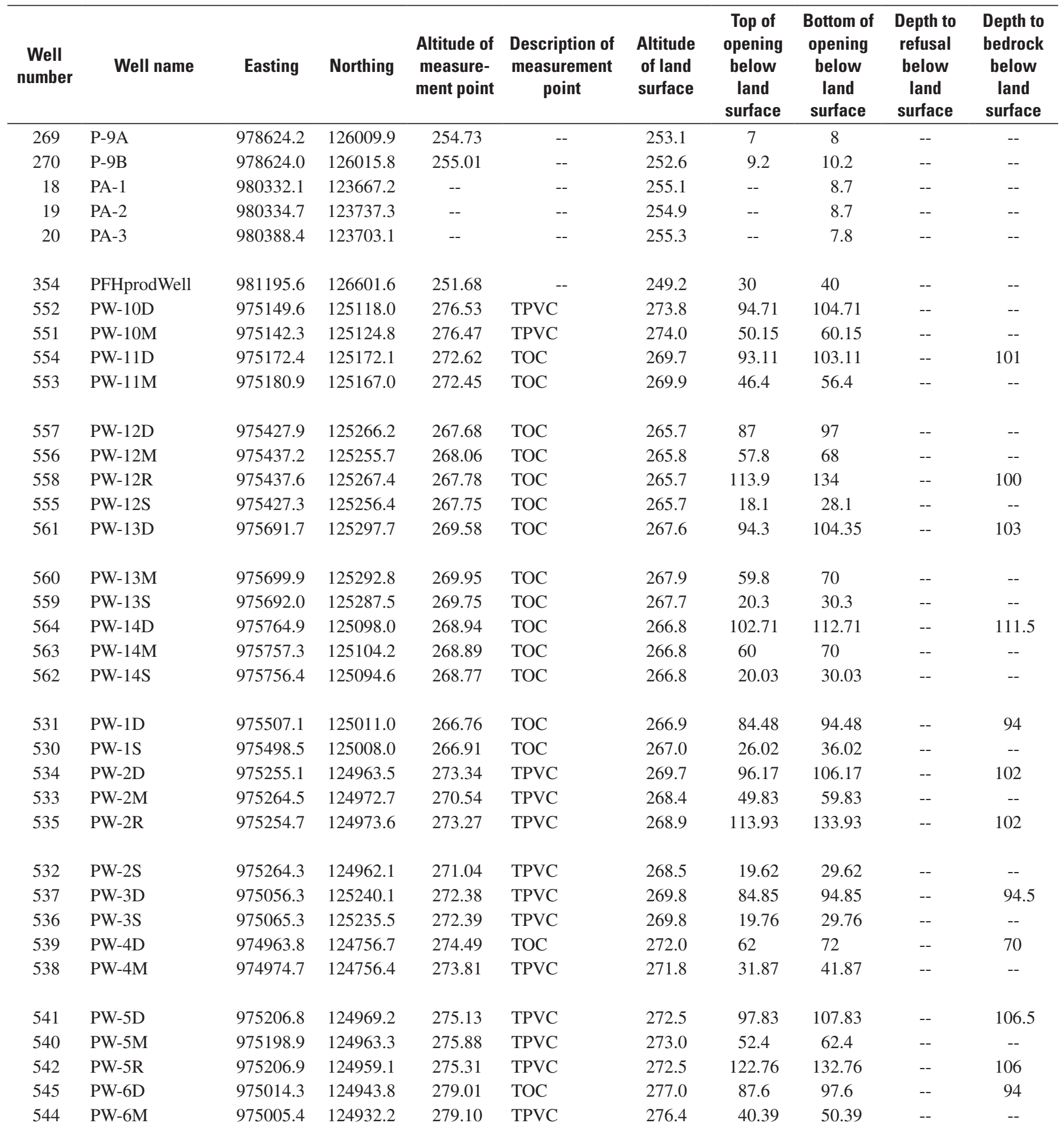


Appendix 1. Information on wells and vertical profile points, Savage Municipal Well Superfund site, Milford, N.H.—Continued

[All units in feet; Horizontal datum based on 2,000-foot grid New Hampshire State Planar coordinate system North American Datum 1983; vertical datum based on feet above National Geodetic Vertical Datum 1929; depth in feet below land surface; well name descriptions on page ix in this report; location of some wells are on figure 2; some wells not shown on figure 2; --, no data; wells are sorted alphabetically. Description of measurement point: TSC, top of steel casing; TPVC, top of polyvinyl chloride pipe; shelter, top of shelter floor; SG, staff gage; SG2, second staff gage; SG3, third staff gage; SG4, fourth staff gage; TCONC, top of concrete; RIM, rim of manhole cover; BOLT HEAD, top of bolt; WELLCVR, well cover; TINRSC, top of inner steel casing; AHPUMP, air line reading at pump; top rebar, top of rebar pipe; USGS disc, top of U.S. Geological Survey disc; VENT, vent hole at pump; TOC, top of casing; PWMC, production well metal casing]

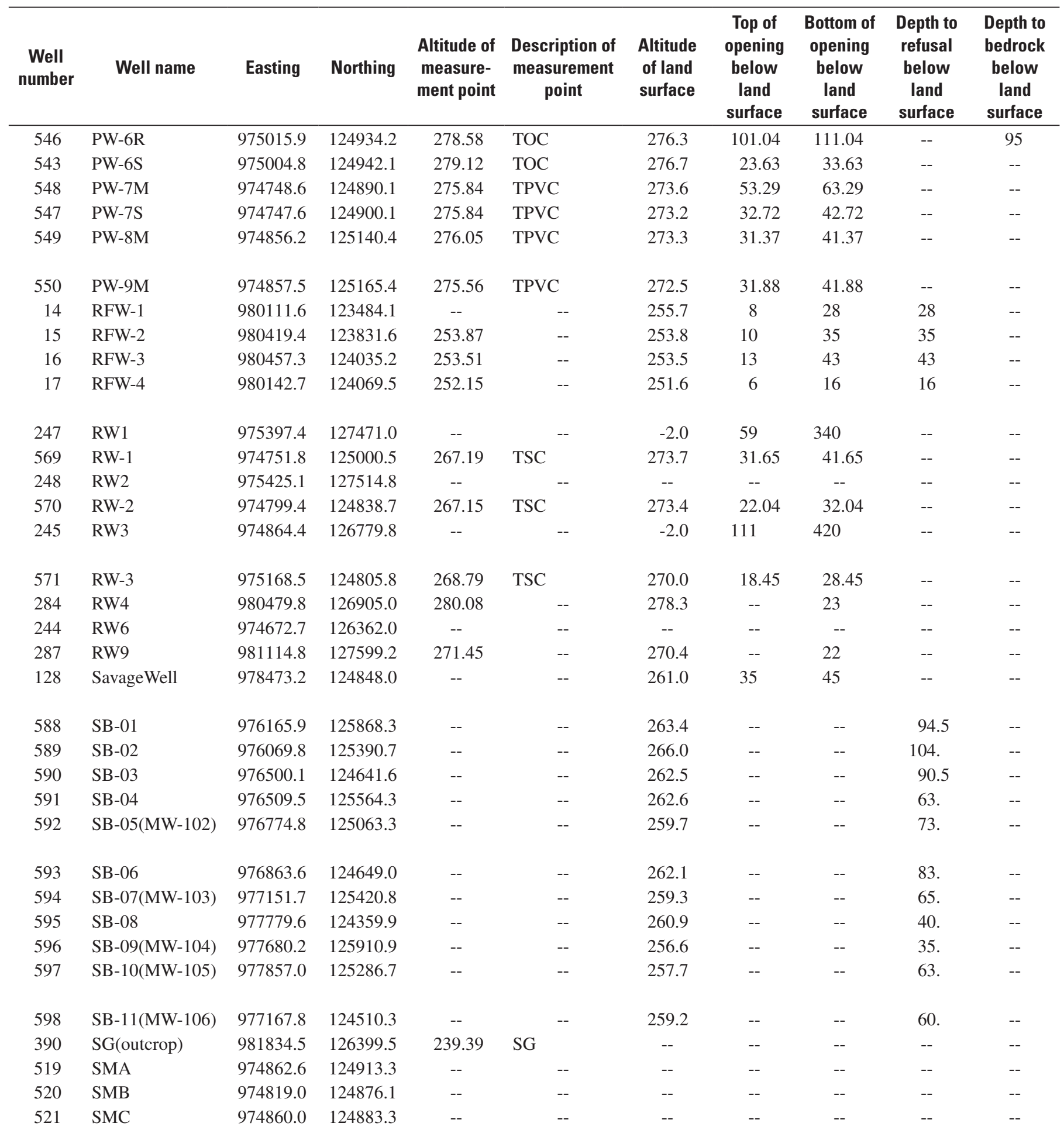


Appendix 1. Information on wells and vertical profile points, Savage Municipal Well Superfund site, Milford, N.H.—Continued

[All units in feet; Horizontal datum based on 2,000-foot grid New Hampshire State Planar coordinate system North American Datum 1983; vertical datum based on feet above National Geodetic Vertical Datum 1929; depth in feet below land surface; well name descriptions on page ix in this report; location of some wells are on figure 2; some wells not shown on figure 2; --, no data; wells are sorted alphabetically. Description of measurement point: TSC, top of steel casing; TPVC, top of polyvinyl chloride pipe; shelter, top of shelter floor; SG, staff gage; SG2, second staff gage; SG3, third staff gage; SG4, fourth staff gage; TCONC, top of concrete; RIM, rim of manhole cover; BOLT HEAD, top of bolt; WELLCVR, well cover; TINRSC, top of inner steel casing; AHPUMP, air line reading at pump; top rebar, top of rebar pipe; USGS disc, top of U.S. Geological Survey disc; VENT, vent hole at pump; TOC, top of casing; PWMC, production well metal casing]

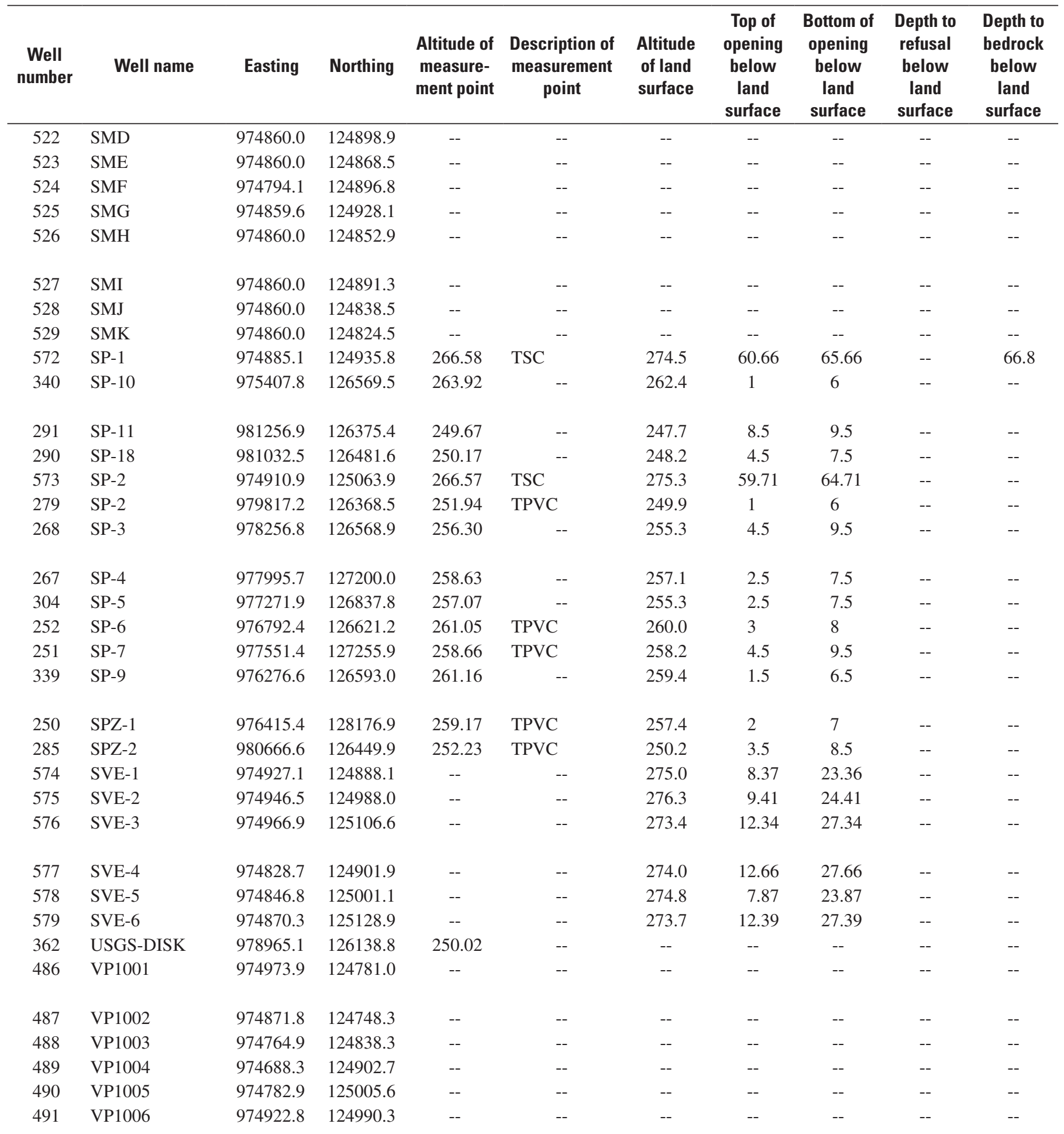


Appendix 1. Information on wells and vertical profile points, Savage Municipal Well Superfund site, Milford, N.H.-Continued

[All units in feet; Horizontal datum based on 2,000-foot grid New Hampshire State Planar coordinate system North American Datum 1983; vertical datum based on feet above National Geodetic Vertical Datum 1929; depth in feet below land surface; well name descriptions on page ix in this report; location of some wells are on figure 2; some wells not shown on figure 2; --, no data; wells are sorted alphabetically. Description of measurement point: TSC, top of steel casing; TPVC, top of polyvinyl chloride pipe; shelter, top of shelter floor; SG, staff gage; SG2, second staff gage; SG3, third staff gage; SG4, fourth staff gage; TCONC, top of concrete; RIM, rim of manhole cover; BOLT HEAD, top of bolt; WELLCVR, well cover; TINRSC, top of inner steel casing; AHPUMP, air line reading at pump; top rebar, top of rebar pipe; USGS disc, top of U.S. Geological Survey disc; VENT, vent hole at pump; TOC, top of casing; PWMC, production well metal casing]

\begin{tabular}{|c|c|c|c|c|c|c|c|c|c|c|}
\hline $\begin{array}{c}\text { Well } \\
\text { number }\end{array}$ & Well name & Easting & Northing & $\begin{array}{l}\text { Altitude of } \\
\text { measure- } \\
\text { ment point }\end{array}$ & $\begin{array}{c}\text { Description of } \\
\text { measurement } \\
\text { point }\end{array}$ & $\begin{array}{l}\text { Altitude } \\
\text { of land } \\
\text { surface }\end{array}$ & $\begin{array}{c}\text { Top of } \\
\text { opening } \\
\text { below } \\
\text { land } \\
\text { surface }\end{array}$ & $\begin{array}{c}\text { Bottom of } \\
\text { opening } \\
\text { below } \\
\text { land } \\
\text { surface }\end{array}$ & $\begin{array}{c}\text { Depth to } \\
\text { refusal } \\
\text { below } \\
\text { land } \\
\text { surface }\end{array}$ & $\begin{array}{c}\text { Depth to } \\
\text { bedrock } \\
\text { below } \\
\text { land } \\
\text { surface }\end{array}$ \\
\hline 492 & VP1007 & 974916.6 & 125089.2 & -- & -- & -- & -- & -- & -- & -- \\
\hline 493 & VP1008 & 974843.1 & 124868.1 & -- & -- & -- & -- & -- & -- & -- \\
\hline 494 & VP1010 & 974662.1 & 125064.6 & -- & -- & -- & -- & -- & -- & -- \\
\hline 495 & VP1011 & 974753.9 & 125052.5 & -- & -- & -- & -- & -- & -- & -- \\
\hline 496 & VP1012 & 974838.8 & 125051.6 & -- & -- & -- & -- & -- & -- & -- \\
\hline 497 & VP1013 & 974958.5 & 125128.4 & -- & -- & -- & -- & -- & -- & -- \\
\hline 498 & VP1014 & 974834.1 & 125154.4 & -- & -- & -- & -- & -- & -- & -- \\
\hline 499 & VP1015 & 974917.1 & 125191.6 & -- & -- & -- & -- & -- & -- & -- \\
\hline 500 & VP1016 & 974686.8 & 124998.9 & -- & -- & -- & -- & -- & -- & -- \\
\hline 501 & VP2001 & 975032.6 & 125199.6 & -- & -- & -- & -- & -- & -- & -- \\
\hline 502 & VP2002 & 975054.8 & 125116.5 & -- & -- & -- & -- & -- & -- & -- \\
\hline 503 & VP2003 & 975053.1 & 125046.1 & -- & -- & -- & -- & -- & -- & -- \\
\hline 504 & VP2004 & 975053.1 & 124962.3 & -- & -- & -- & -- & -- & -- & -- \\
\hline 505 & VP2005 & 975088.4 & 124827.3 & -- & -- & -- & -- & -- & -- & -- \\
\hline 506 & VP2006 & 975054.5 & 125003.6 & -- & -- & -- & -- & -- & -- & -- \\
\hline 507 & VP2007 & 975060.1 & 124892.2 & -- & -- & -- & -- & -- & -- & -- \\
\hline 508 & VP2008 & 975143.9 & 124858.0 & -- & -- & -- & -- & -- & -- & -- \\
\hline 509 & VP3002 & 975183.2 & 125171.2 & -- & -- & -- & -- & -- & -- & -- \\
\hline 510 & VP3003 & 975217.8 & 125071.9 & -- & -- & -- & -- & -- & -- & -- \\
\hline 511 & VP3004 & 975233.4 & 124979.3 & -- & -- & -- & -- & -- & -- & -- \\
\hline 512 & VP3005 & 975197.6 & 124894.6 & -- & -- & -- & -- & -- & -- & -- \\
\hline 513 & VP3006 & 975313.6 & 124781.6 & -- & -- & -- & -- & -- & -- & -- \\
\hline 514 & VP4001 & 975384.6 & 125246.0 & -- & -- & -- & -- & -- & -- & -- \\
\hline 515 & VP4002 & 975598.9 & 125229.8 & -- & -- & -- & -- & -- & -- & -- \\
\hline 516 & VP4003 & 975631.1 & 125083.4 & -- & -- & -- & -- & -- & -- & -- \\
\hline 517 & VP4004 & 975598.7 & 124960.9 & -- & -- & -- & -- & -- & -- & -- \\
\hline 518 & VP4006 & 975711.6 & 124809.1 & -- & -- & -- & -- & -- & -- & -- \\
\hline 391 & WLR-1 & 973834.4 & 124843.1 & 282.80 & Shelter & -- & -- & -- & -- & -- \\
\hline 586 & WLR-1 staff & 973834.4 & 124843.1 & 269.21 & SG & -- & -- & -- & -- & -- \\
\hline 337 & WLR4 & 978297.6 & 125583.7 & 257.38 & Shelter & 251.3 & 4 & 5 & -- & -- \\
\hline 393 & WLR-5 & 980644.9 & 126283.6 & 254.27 & Shelter & -- & -- & -- & -- & -- \\
\hline 585 & WLR-5 rebar & 980644.9 & 126283.6 & 245.24 & Top rebar & -- & -- & -- & -- & -- \\
\hline 122 & WW-125 & 975152.7 & 129134.8 & -- & -- & 269.0 & -- & -- & -- & -- \\
\hline
\end{tabular}


Appendix 2. Tetrachloroethylene concentrations for data points used in figure 14, Operable Unit 1 (OU1), Savage Municipal Well Superfund site, Milford, N.H.

[Location of wells shown on figure 2. PCE, tetracholoroethylene; Depth code: shallow is 0-40 feet below land surface, medium is 40.1-70 feet, deep is 70.1 feet to bedrock; VP, vertical profile; wells have only one sample collected per depth code, whereas VP points have a minimum of three samples collected per depth code; site type names explained in abbreviation section of report; Source of data: Camp, Dresser, and McKee, Inc. (2001)]

\begin{tabular}{|c|c|c|c|c|}
\hline Well number & Name & Depth code & $\begin{array}{c}\text { Maximum PCE concentration, } \\
\text { in micrograms per liter }\end{array}$ & $\begin{array}{l}\text { Median PCE concentration, } \\
\text { in micrograms per liter }\end{array}$ \\
\hline 630 & VP5001 & Shallow & 840.0 & 219.0 \\
\hline 631 & VP5002 & Shallow & 670.0 & 140.0 \\
\hline 632 & VP5003 & Shallow & 481.0 & 69.5 \\
\hline 633 & VP5004 & Shallow & 603.0 & 76.0 \\
\hline 634 & VP5005 & Shallow & $1,595.0$ & 743.0 \\
\hline 635 & VP5006 & Shallow & 321.0 & 50.0 \\
\hline 636 & VP5007 & Shallow & 589.0 & 124.5 \\
\hline 637 & VP5008 & Shallow & 556.0 & 286.5 \\
\hline 638 & VP5009 & Shallow & $1,543.0$ & 130.0 \\
\hline 233 & MW-16A & Shallow & 7.8 & 7.8 \\
\hline 235 & MW-27 & Shallow & 2.0 & 2.0 \\
\hline 404 & B95-9 & Shallow & 190.0 & 190.0 \\
\hline 530 & PW-1S & Shallow & 370.0 & 370.0 \\
\hline 532 & PW-2S & Shallow & 19.0 & 19.0 \\
\hline 536 & PW-3S & Shallow & 2.0 & 2.0 \\
\hline 538 & PW-4M & Shallow & 2.0 & 2.0 \\
\hline 543 & PW-6S & Shallow & $6,200.0$ & $6,200.0$ \\
\hline 547 & PW-7S & Shallow & 2.0 & 2.0 \\
\hline 549 & PW-8M & Shallow & 88.0 & 88.0 \\
\hline 550 & PW-9M & Shallow & 2.0 & 2.0 \\
\hline 555 & PW-12S & Shallow & 13.0 & 13.0 \\
\hline 559 & PW-13S & Shallow & 180.0 & 180.0 \\
\hline 562 & PW-14S & Shallow & 220.0 & 220.0 \\
\hline 1 & NWP & Shallow & 532.0 & 480.0 \\
\hline 2 & SWP & Shallow & 178.0 & 125.0 \\
\hline 3 & $\mathrm{CI}$ & Shallow & 109.0 & 97.5 \\
\hline 4 & NEP & Shallow & $7,170.0$ & $6,940.0$ \\
\hline 5 & SEP & Shallow & 1.4 & 1.0 \\
\hline 630 & vp5001 & Medium & $1,203.0$ & 152.00 \\
\hline 631 & VP5002 & Medium & 154.0 & 57.00 \\
\hline 632 & VP5003 & Medium & 444.0 & 130.50 \\
\hline 633 & VP5004 & Medium & 886.0 & 291.50 \\
\hline 634 & VP5005 & Medium & 302.0 & 119.00 \\
\hline 635 & VP5006 & Medium & 579.0 & 352.00 \\
\hline 636 & VP5007 & Medium & 16.0 & 4.50 \\
\hline
\end{tabular}


Appendix 2. Tetrachloroethylene concentrations for data points used in figure 14, Operable Unit 1 (OU1), Savage Municipal Well Superfund site, Milford, N.H._Continued

[Location of wells shown on figure 2. PCE, tetracholoroethylene; Depth code: shallow is $0-40$ feet below land surface, medium is 40.1-70 feet, deep is 70.1 feet to bedrock; VP, vertical profile; wells have only one sample collected per depth code, whereas VP points have a minimum of three samples collected per depth code; site type names explained in abbreviation section of report; Source of data: Camp, Dresser, and McKee, Inc. (2001)]

\begin{tabular}{|c|c|c|c|c|}
\hline Well number & Name & Depth code & $\begin{array}{c}\text { Maximum PCE concentration, } \\
\text { in micrograms per liter }\end{array}$ & $\begin{array}{l}\text { Median PCE concentration, } \\
\text { in micrograms per liter }\end{array}$ \\
\hline 637 & VP5008 & Medium & 145.0 & 1.85 \\
\hline 638 & VP5009 & Medium & 510.0 & 2.68 \\
\hline 46 & MI-32 & Medium & 150.0 & 150.00 \\
\hline 321 & MW-16B & Medium & 4.3 & 4.30 \\
\hline 398 & B95-3 & Medium & 2.0 & 2.00 \\
\hline 400 & B95-5 & Medium & 2.0 & 2.00 \\
\hline 401 & B95-6 & Medium & 2.0 & 2.00 \\
\hline 407 & B95-12 & Medium & 2.0 & 2.00 \\
\hline 408 & B95-13 & Medium & 200.0 & 200.00 \\
\hline 533 & PW-2M & Medium & 260.0 & 260.00 \\
\hline 539 & PW-4D & Medium & 2.0 & 2.00 \\
\hline 540 & PW-5M & Medium & 140.0 & 140.00 \\
\hline 544 & PW-6M & Medium & $5,900.0$ & $5,900.00$ \\
\hline 548 & PW-7M & Medium & 2.5 & 2.50 \\
\hline 551 & PW-10M & Medium & 210.0 & 210.00 \\
\hline 553 & PW-11M & Medium & 4.7 & 4.70 \\
\hline 556 & PW-12M & Medium & 70.0 & 70.00 \\
\hline 560 & PW-13M & Medium & 120.0 & 120.00 \\
\hline 563 & PW-14M & Medium & 600.0 & 600.00 \\
\hline 1 & NWP & Medium & 573.0 & 558.00 \\
\hline 2 & SWP & Medium & 226.0 & 204.00 \\
\hline 3 & CI & Medium & $29,500.0$ & 529.00 \\
\hline 4 & NEP & Medium & $20,200.0$ & $8,875.00$ \\
\hline 5 & SEP & Medium & 8.7 & 1.10 \\
\hline 630 & VP5001 & Deep & 750.0 & 422.00 \\
\hline 631 & VP5002 & Deep & 656.0 & 353.00 \\
\hline 633 & VP5004 & Deep & 526.0 & 240.50 \\
\hline 634 & VP5005 & Deep & 194.0 & 174.00 \\
\hline 635 & VP5006 & Deep & $1,033.0$ & 933.50 \\
\hline 636 & VP5007 & Deep & 9.1 & 4.95 \\
\hline 637 & VP5008 & Deep & 0.8 & 0.75 \\
\hline 638 & VP5009 & Deep & 662.0 & 639.50 \\
\hline 344 & MW-16C & Deep & 170.0 & 170.00 \\
\hline 403 & B95-8 & Deep & 4.7 & 4.70 \\
\hline 409 & B95-15 & Deep & 43.0 & 43.00 \\
\hline
\end{tabular}


Appendix 2. Tetrachloroethylene concentrations for data points used in figure 14, Operable Unit 1 (OU1), Savage Municipal Well Superfund site, Milford, N.H.-Continued

[Location of wells shown on figure 2. PCE, tetracholoroethylene; Depth code: shallow is $0-40$ feet below land surface, medium is 40.1-70 feet, deep is 70.1 feet to bedrock; VP, vertical profile; wells have only one sample collected per depth code, whereas VP points have a minimum of three samples collected per depth code; site type names explained in abbreviation section of report; Source of data: Camp, Dresser, and McKee, Inc. (2001)]

\begin{tabular}{cllcc}
\hline Well number & Name & Depth code & $\begin{array}{c}\text { Maximum PCE concentration, } \\
\text { in micrograms per liter }\end{array}$ & $\begin{array}{c}\text { Median PCE concentration, } \\
\text { in micrograms per liter }\end{array}$ \\
\hline 531 & PW-1D & Deep & 370.0 & 370.00 \\
534 & PW-2D & Deep & 320.0 & 320.00 \\
537 & PW-3D & Deep & 2.0 & 2.00 \\
541 & PW-5D & Deep & 190.0 & 190.00 \\
545 & PW-6D & Deep & $16,000.0$ & $16,000.00$ \\
& & & & \\
552 & PW-10D & Deep & 660.0 & 660.00 \\
554 & PW-11D & Deep & 9.1 & 9.10 \\
557 & PW-12D & Deep & 110.0 & 710.00 \\
561 & PW-13D & Deep & 790.0 & 790.00 \\
564 & PW-14D & Deep & 910.0 & 910.00 \\
\hline
\end{tabular}


Appendix 3. Information on barrier-trench depths, Operable Unit 1 (OU1), Savage Municipal Well Superfund site, Milford, N.H.

[NAD 83, North American Datum 1983; NGVD 29, altitude in feet above National Geodetic Vertical Datum of 1929; --, no data; 13+15, reference line segment 13, station number 15 shown on figure 17; Source of data: Sverdrup Environmental, Inc., written commun., 1999]

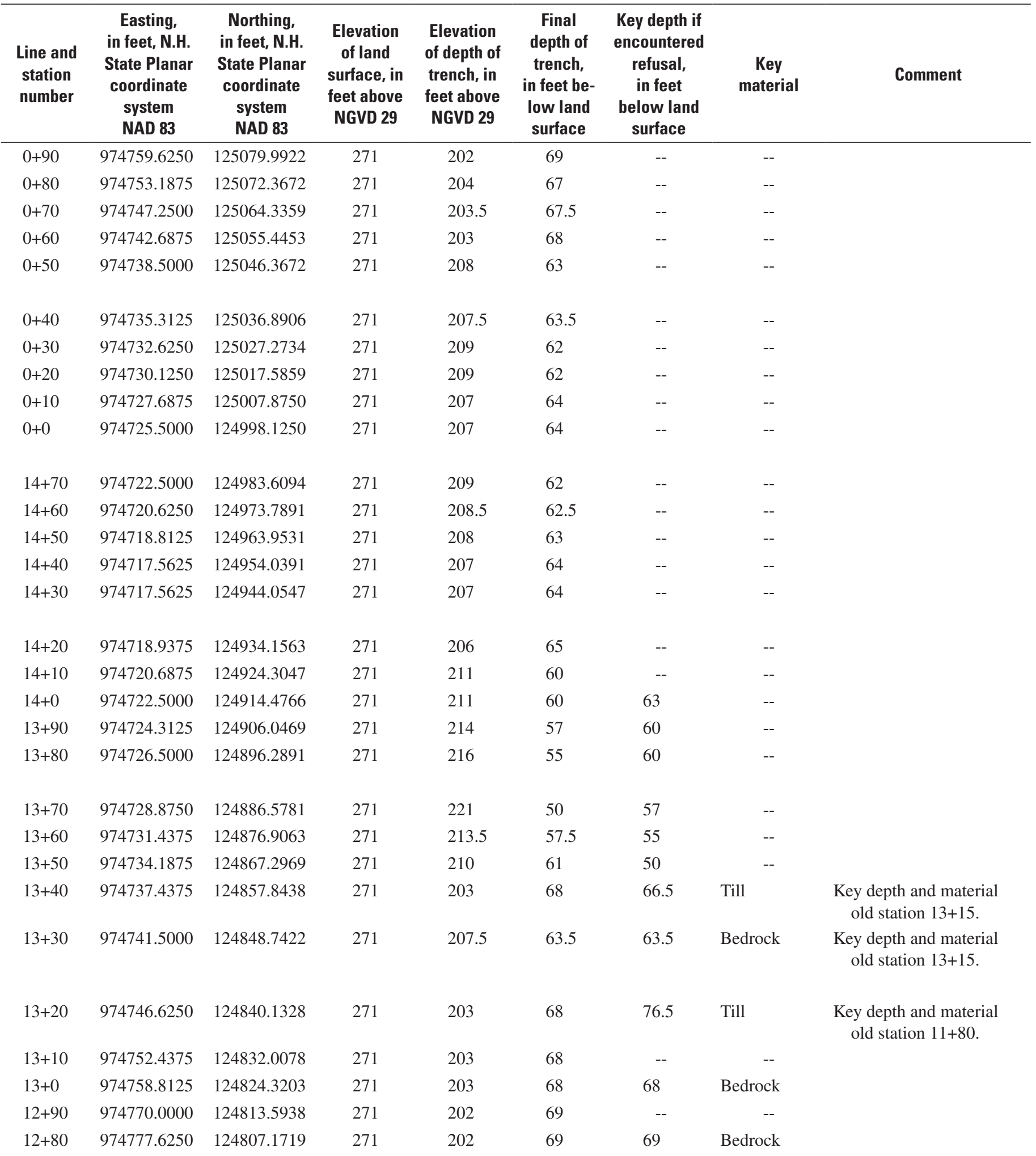


Appendix 3. Information on barrier-trench depths, Operable Unit 1 (OU1), Savage Municipal Well Superfund site, Milford, N.H. - Continued

[NAD 83, North American Datum 1983; NGVD 29, altitude in feet above National Geodetic Vertical Datum of 1929; --, no data; 13+15, reference line segment 13, station number 15 shown on figure 17; Source of data: Sverdrup Environmental, Inc., written commun., 1999]

\begin{tabular}{|c|c|c|c|c|c|c|c|c|}
\hline $\begin{array}{l}\text { Line and } \\
\text { station } \\
\text { number }\end{array}$ & $\begin{array}{c}\text { Easting, } \\
\text { in feet, N.H. } \\
\text { State Planar } \\
\text { coordinate } \\
\text { system } \\
\text { NAD } 83\end{array}$ & $\begin{array}{l}\text { Northing, } \\
\text { in feet, N.H. } \\
\text { State Planar } \\
\text { coordinate } \\
\text { system } \\
\text { NAD } 83\end{array}$ & $\begin{array}{l}\text { Elevation } \\
\text { of land } \\
\text { surface, in } \\
\text { feet above } \\
\text { NGVD } 29\end{array}$ & $\begin{array}{l}\text { Elevation } \\
\text { of depth of } \\
\text { trench, in } \\
\text { feet above } \\
\text { NGVD } 29\end{array}$ & $\begin{array}{l}\text { Final } \\
\text { depth of } \\
\text { trench, } \\
\text { in feet be- } \\
\text { low land } \\
\text { surface }\end{array}$ & $\begin{array}{l}\text { Key depth if } \\
\text { encountered } \\
\text { refusal, } \\
\text { in feet } \\
\text { below land } \\
\text { surface }\end{array}$ & $\begin{array}{c}\text { Key } \\
\text { material }\end{array}$ & Comment \\
\hline $12+70$ & 974785.9375 & 124801.6641 & 271 & 202 & 69 & -- & -- & \\
\hline $12+60$ & 974794.8750 & 124797.2031 & 271 & 202 & 69 & 69 & Bedrock & \\
\hline $12+50$ & 974804.0000 & 124793.0469 & 271 & 197 & 74 & -- & -- & \\
\hline $12+40$ & 974813.3750 & 124789.5547 & 271 & 197.5 & 73.5 & -- & -- & \\
\hline $12+30$ & 974822.9375 & 124786.6563 & 271 & 199 & 72 & -- & -- & \\
\hline $12+20$ & 974832.6250 & 124784.1563 & 271 & 194 & 77 & -- & -- & \\
\hline $12+10$ & 974842.4375 & 124782.5156 & 271 & 200.5 & 70.5 & -- & -- & \\
\hline $12+0$ & 974852.3750 & 124781.2500 & 271 & 201 & 70 & 72 & Till & \\
\hline $11+90$ & 974863.0625 & 124780.6797 & 271 & 202 & 69 & -- & -- & \\
\hline $11+80$ & 974873.0625 & 124780.4141 & 271 & 212 & 59 & -- & -- & \\
\hline $11+70$ & 974883.0625 & 124780.2344 & 271 & 212 & 59 & 68 & Bedrock & \\
\hline $11+60$ & 974893.0625 & 124780.1641 & 271 & 206 & 65 & 65 & Bedrock & \\
\hline $11+50$ & 974903.0625 & 124780.4219 & 271 & 204 & 67 & 67 & Bedrock & \\
\hline $11+40$ & 974913.0625 & 124780.9063 & 271 & 203.5 & 67.5 & -- & -- & \\
\hline $11+30$ & 974923.0625 & 124781.4141 & 271 & 203.5 & 67.5 & -- & -- & \\
\hline $11+20$ & 974933.0000 & 124781.9219 & 271 & 205.5 & 65.5 & -- & -- & \\
\hline $11+10$ & 974943.0000 & 124782.4453 & 271 & 207.5 & 63.5 & -- & -- & \\
\hline $11+0$ & 974953.0000 & 124783.0234 & 271 & 210.5 & 60.5 & -- & -- & \\
\hline $10+90$ & 974963.2500 & 124783.7031 & 271 & 208.5 & 62.5 & -- & -- & \\
\hline $10+80$ & 974973.1875 & 124784.3906 & 271 & 206 & 65 & 63 & Bedrock & \\
\hline $10+70$ & 974983.1875 & 124785.0781 & 271 & 204.5 & 66.5 & 67.5 & Bedrock & \\
\hline $10+60$ & 974993.1875 & 124785.7656 & 271 & 198.5 & 72.5 & 69 & Bedrock & \\
\hline $10+50$ & 975003.1250 & 124786.5156 & 271 & 196.5 & 74.5 & 75 & Bedrock & \\
\hline $10+40$ & 975013.0625 & 124787.5156 & 271 & 197 & 74 & 75.5 & Bedrock & \\
\hline $10+30$ & 975023.0000 & 124788.5938 & 271 & 195 & 76 & 75.5 & Bedrock & \\
\hline $10+20$ & 975032.9375 & 124789.8516 & 271 & 195 & 76 & 75 & Bedrock & \\
\hline $10+10$ & 975042.6875 & 124791.9766 & 271 & 193.5 & 77.5 & 76.5 & Bedrock & \\
\hline $10+0$ & 975052.4375 & 124794.3125 & 271 & 192.5 & 78.5 & 76.5 & Bedrock & \\
\hline $9+90$ & 975060.3125 & 124796.3594 & 271 & 190 & 81 & -- & -- & \\
\hline $9+80$ & 975069.9375 & 124799.0781 & 271 & 187.5 & 83.5 & 83.5 & Bedrock & \\
\hline
\end{tabular}


Appendix 3. Information on barrier-trench depths, Operable Unit 1 (OU1), Savage Municipal Well Superfund site, Milford, N.H. -Continued

[NAD 83, North American Datum 1983; NGVD 29, altitude in feet above National Geodetic Vertical Datum of 1929; --, no data; 13+15, reference line segment 13, station number 15 shown on figure 17; Source of data: Sverdrup Environmental, Inc., written commun., 1999]

\begin{tabular}{|c|c|c|c|c|c|c|c|c|}
\hline $\begin{array}{l}\text { Line and } \\
\text { station } \\
\text { number }\end{array}$ & $\begin{array}{c}\text { Easting, } \\
\text { in feet, } \mathbf{N} . \mathrm{H} . \\
\text { State Planar } \\
\text { coordinate } \\
\text { system } \\
\text { NAD } 83\end{array}$ & $\begin{array}{l}\text { Northing, } \\
\text { in feet, N.H. } \\
\text { State Planar } \\
\text { coordinate } \\
\text { system } \\
\text { NAD } 83\end{array}$ & $\begin{array}{l}\text { Elevation } \\
\text { of land } \\
\text { surface, in } \\
\text { feet above } \\
\text { NGVD } 29\end{array}$ & $\begin{array}{l}\text { Elevation } \\
\text { of depth of } \\
\text { trench, in } \\
\text { feet above } \\
\text { NGVD } 29\end{array}$ & $\begin{array}{l}\text { Final } \\
\text { depth of } \\
\text { trench, } \\
\text { in feet be- } \\
\text { low land } \\
\text { surface }\end{array}$ & $\begin{array}{l}\text { Key depth if } \\
\text { encountered } \\
\text { refusal, } \\
\text { in feet } \\
\text { below land } \\
\text { surface }\end{array}$ & $\begin{array}{c}\text { Key } \\
\text { material }\end{array}$ & Comment \\
\hline $9+70$ & 975079.4375 & 124802.2344 & 271 & 183 & 88 & 88 & Bedrock & \\
\hline $9+60$ & 975088.7500 & 124805.8750 & 271 & 181 & 90 & 90 & Bedrock & \\
\hline $9+50$ & 975097.8750 & 124809.8672 & 271 & 181.5 & 89.5 & -- & -- & \\
\hline $9+40$ & 975107.0625 & 124813.9141 & 271 & 180 & 91 & 91 & Bedrock & \\
\hline $9+30$ & 975116.1875 & 124817.9609 & 271 & 179 & 92 & 92 & Till & \\
\hline $9+20$ & 975125.3125 & 124822.0000 & 271 & 175 & 96 & 96 & Till & \\
\hline $9+10$ & 975134.2500 & 124826.5078 & 271 & 182 & 89 & -- & -- & \\
\hline $9+0$ & 975142.8125 & 124831.6875 & 271 & 182 & 89 & -- & -- & \\
\hline $8+90$ & 975150.1875 & 124836.9609 & 271 & 180 & 91 & -- & -- & \\
\hline $8+80$ & 975158.2500 & 124842.8672 & 271 & 179.5 & 91.5 & 91.5 & $\begin{array}{l}\text { Bedrock/ } \\
\text { Boulders } \\
\text { in Till }\end{array}$ & \\
\hline $8+70$ & 975166.2500 & 124848.8906 & 271 & 171.5 & 99.5 & 99.5 & Till & \\
\hline $8+60$ & 975174.1875 & 124855.0234 & 271 & 173.5 & 97.5 & -- & -- & \\
\hline $8+50$ & 975181.8125 & 124861.4453 & 271 & 174 & 97 & -- & -- & \\
\hline $8+40$ & 975189.1250 & 124868.2656 & 271 & 177 & 94 & -- & -- & \\
\hline $8+30$ & 975196.0625 & 124875.4609 & 271 & 179 & 92 & 92 & Bedrock & \\
\hline $8+20$ & 975202.2500 & 124883.3125 & 271 & 173 & 98 & 98.5 & Till & \\
\hline $8+10$ & 975208.1250 & 124891.4063 & 271 & 180.5 & 90.5 & -- & -- & \\
\hline $8+0$ & 975213.7500 & 124899.6484 & 271 & 180 & 91 & -- & -- & \\
\hline $7+90$ & 975218.0625 & 124908.8047 & 271 & 178 & 93 & 93 & Bedrock/Till & \\
\hline $7+80$ & 975221.1250 & 124918.3047 & 271 & 172 & 99 & 99 & Till & \\
\hline $7+70$ & 975223.3750 & 124928.0391 & 271 & 173.5 & 97.5 & -- & -- & \\
\hline $7+60$ & 975224.1250 & 124938.0078 & 271 & 173.5 & 97.5 & -- & -- & \\
\hline $7+50$ & 975224.8125 & 124947.9844 & 271 & 166 & 105 & 105 & Till & \\
\hline $7+40$ & 975225.5625 & 124957.9531 & 271 & 172.5 & 98.5 & -- & -- & \\
\hline $7+30$ & 975226.2500 & 124967.9297 & 271 & 172 & 99 & -- & -- & \\
\hline $7+20$ & 975226.7500 & 124977.9063 & 271 & 169 & 102 & -- & -- & \\
\hline $7+10$ & 975226.4375 & 124987.9063 & 271 & 161.5 & 109.5 & 109.5 & Bedrock & \\
\hline $7+0$ & 975225.9375 & 124997.8906 & 271 & 163.5 & 107.5 & 88.5 & Bedrock & \\
\hline $6+90$ & 975225.0625 & 125008.4844 & 271 & 164.5 & 106.5 & -- & -- & \\
\hline $6+80$ & 975224.0000 & 125018.4297 & 271 & 164 & 107 & -- & -- & \\
\hline
\end{tabular}


Appendix 3. Information on barrier-trench depths, Operable Unit 1 (OU1), Savage Municipal Well Superfund site, Milford, N.H. - Continued

[NAD 83, North American Datum 1983; NGVD 29, altitude in feet above National Geodetic Vertical Datum of 1929; --, no data; 13+15, reference line segment 13, station number 15 shown on figure 17; Source of data: Sverdrup Environmental, Inc., written commun., 1999]

\begin{tabular}{|c|c|c|c|c|c|c|c|c|}
\hline $\begin{array}{l}\text { Line and } \\
\text { station } \\
\text { number }\end{array}$ & $\begin{array}{c}\text { Easting, } \\
\text { in feet, N.H. } \\
\text { State Planar } \\
\text { coordinate } \\
\text { system } \\
\text { NAD } 83\end{array}$ & $\begin{array}{c}\text { Northing, } \\
\text { in feet, N.H. } \\
\text { State Planar } \\
\text { coordinate } \\
\text { system } \\
\text { NAD } 83\end{array}$ & $\begin{array}{l}\text { Elevation } \\
\text { of land } \\
\text { surface, in } \\
\text { feet above } \\
\text { NGVD } 29\end{array}$ & $\begin{array}{l}\text { Elevation } \\
\text { of depth of } \\
\text { trench, in } \\
\text { feet above } \\
\text { NGVD } 29\end{array}$ & $\begin{array}{c}\text { Final } \\
\text { depth of } \\
\text { trench, } \\
\text { in feet be- } \\
\text { low land } \\
\text { surface }\end{array}$ & $\begin{array}{l}\text { Key depth if } \\
\text { encountered } \\
\text { refusal, } \\
\text { in feet } \\
\text { below land } \\
\text { surface }\end{array}$ & $\begin{array}{c}\text { Key } \\
\text { material }\end{array}$ & Comment \\
\hline $6+70$ & 975222.1875 & 125028.2500 & 271 & 164 & 107 & -- & -- & \\
\hline $6+60$ & 975220.0625 & 125038.0313 & 271 & 171.5 & 99.5 & 99.5 & Bedrock & \\
\hline $6+50$ & 975217.9375 & 125047.7813 & 271 & 161 & 110 & 110 & Bedrock & \\
\hline $6+40$ & 975214.7500 & 125057.2656 & 271 & 161 & 110 & 109 & Till & \\
\hline $6+30$ & 975211.0625 & 125066.5781 & 271 & 164 & 107 & -- & -- & \\
\hline $6+20$ & 975207.0625 & 125075.7344 & 271 & 165 & 106 & -- & -- & \\
\hline $6+10$ & 975202.3125 & 125084.5156 & 271 & 165 & 106 & 106 & Bedrock & \\
\hline $6+0$ & 975197.1250 & 125093.0625 & 271 & 166.5 & 104.5 & 104.5 & Bedrock & \\
\hline $5+90$ & 975192.7500 & 125100.2578 & 271 & 167 & 104 & 104 & Bedrock & \\
\hline $5+80$ & 975187.0625 & 125108.4688 & 271 & 167.5 & 103.5 & -- & -- & \\
\hline $5+70$ & 975180.8125 & 125116.2969 & 271 & 168 & 103 & -- & -- & \\
\hline $5+60$ & 975174.3125 & 125123.8750 & 271 & 168 & 103 & 103 & Bedrock & \\
\hline $5+50$ & 975167.5000 & 125131.2344 & 271 & 169 & 102 & 102 & Bedrock & \\
\hline $5+40$ & 975160.4375 & 125138.2969 & 271 & 168.5 & 102.5 & -- & -- & \\
\hline $5+30$ & 975153.0625 & 125145.0547 & 271 & 167.5 & 103.5 & -- & -- & \\
\hline $5+20$ & 975145.4375 & 125151.5000 & 271 & 167 & 104 & -- & -- & \\
\hline $5+10$ & 975137.6250 & 125157.7188 & 271 & 163 & 108 & 108 & Bedrock & \\
\hline $5+0$ & 975129.5625 & 125163.6641 & 271 & 162 & 109 & 109 & Bedrock & \\
\hline $4+90$ & 975121.2500 & 125169.2578 & 271 & 164.5 & 106.5 & 106.5 & Bedrock & \\
\hline $4+80$ & 975112.5000 & 125174.0469 & 271 & 161.5 & 109.5 & -- & -- & \\
\hline $4+70$ & 975103.3750 & 125178.1875 & 271 & 163 & 108 & -- & -- & \\
\hline $4+60$ & 975094.0625 & 125181.8750 & 271 & 166 & 105 & -- & -- & \\
\hline $4+50$ & 975084.6250 & 125185.1328 & 271 & 169 & 102 & 102 & Bedrock & \\
\hline $4+40$ & 975075.0625 & 125188.0625 & 271 & 175 & 96 & 96 & Bedrock & \\
\hline $4+30$ & 975065.4375 & 125190.6406 & 271 & 182 & 89 & 89 & Bedrock & \\
\hline $4+20$ & 975055.6875 & 125192.9063 & 271 & 182 & 89 & -- & -- & \\
\hline $4+10$ & 975045.8750 & 125194.9766 & 271 & 186 & 85 & -- & -- & \\
\hline $4+0$ & 975036.0625 & 125196.8359 & 271 & 187 & 84 & 84 & Bedrock & \\
\hline $3+90$ & 975025.9375 & 125198.3828 & 271 & 188 & 83 & -- & -- & \\
\hline $3+80$ & 975016.0000 & 125199.4609 & 271 & 187.5 & 83.5 & -- & -- & \\
\hline
\end{tabular}


Appendix 3. Information on barrier-trench depths, Operable Unit 1 (OU1), Savage Municipal Well Superfund site, Milford, N.H. -Continued

[NAD 83, North American Datum 1983; NGVD 29, altitude in feet above National Geodetic Vertical Datum of 1929; --, no data; 13+15, reference line segment 13, station number 15 shown on figure 17; Source of data: Sverdrup Environmental, Inc., written commun., 1999]

\begin{tabular}{|c|c|c|c|c|c|c|c|c|}
\hline $\begin{array}{l}\text { Line and } \\
\text { station } \\
\text { number }\end{array}$ & $\begin{array}{c}\text { Easting, } \\
\text { in feet, N.H. } \\
\text { State Planar } \\
\text { coordinate } \\
\text { system } \\
\text { NAD } 83\end{array}$ & $\begin{array}{c}\text { Northing, } \\
\text { in feet, N.H. } \\
\text { State Planar } \\
\text { coordinate } \\
\text { system } \\
\text { NAD } 83\end{array}$ & $\begin{array}{l}\text { Elevation } \\
\text { of land } \\
\text { surface, in } \\
\text { feet above } \\
\text { NGVD } 29\end{array}$ & $\begin{array}{l}\text { Elevation } \\
\text { of depth of } \\
\text { trench, in } \\
\text { feet above } \\
\text { NGVD } 29\end{array}$ & $\begin{array}{l}\text { Final } \\
\text { depth of } \\
\text { trench, } \\
\text { in feet be- } \\
\text { low land } \\
\text { surface }\end{array}$ & $\begin{array}{l}\text { Key depth if } \\
\text { encountered } \\
\text { refusal, } \\
\text { in feet } \\
\text { below land } \\
\text { surface }\end{array}$ & $\begin{array}{c}\text { Key } \\
\text { material }\end{array}$ & Comment \\
\hline $3+70$ & 975006.0000 & 125200.0625 & 271 & 188 & 83 & 83 & Bedrock & \\
\hline $3+60$ & 974996.0000 & 125200.1250 & 271 & 188.5 & 82.5 & -- & -- & \\
\hline $3+50$ & 974986.0625 & 125199.5313 & 271 & 189 & 82 & -- & -- & \\
\hline $3+40$ & 974976.1250 & 125198.3281 & 271 & 188.5 & 82.5 & 83 & Bedrock & \\
\hline $3+30$ & 974966.2500 & 125196.6250 & 271 & 194.5 & 76.5 & -- & -- & \\
\hline $3+20$ & 974956.5000 & 125194.4844 & 271 & 194 & 77 & -- & -- & \\
\hline $3+10$ & 974946.8125 & 125192.0313 & 271 & 194 & 77 & 77 & Bedrock & \\
\hline $3+0$ & 974937.1875 & 125189.3047 & 271 & 195 & 76 & 76 & Bedrock & \\
\hline $2+90$ & 974928.0625 & 125186.4609 & 271 & 196.5 & 74.5 & 77 & Bedrock & \\
\hline $2+80$ & 974918.5625 & 125183.3828 & 271 & 201 & 70 & 77 & Bedrock & \\
\hline $2+70$ & 974909.0625 & 125180.1875 & 271 & 202 & 69 & 69 & Bedrock & \\
\hline $2+60$ & 974899.6875 & 125176.6875 & 271 & 201 & 70 & -- & -- & \\
\hline $2+50$ & 974890.5000 & 125172.8594 & 271 & 200 & 71 & -- & -- & \\
\hline $2+40$ & 974881.3750 & 125168.7188 & 271 & 201.5 & 69.5 & 69.5 & Bedrock & \\
\hline $2+30$ & 974872.4375 & 125164.2578 & 271 & 202 & 69 & 69 & Bedrock & \\
\hline $2+20$ & 974863.6875 & 125159.4375 & 271 & 202.5 & 68.5 & -- & -- & \\
\hline $2+10$ & 974855.1250 & 125154.2422 & 271 & 203 & 68 & -- & -- & \\
\hline $2+0$ & 974846.8125 & 125148.6797 & 271 & 207 & 64 & 64 & Bedrock & \\
\hline $1+90$ & 974839.5000 & 125143.5703 & 271 & 203 & 68 & 61.5 & Bedrock & \\
\hline $1+80$ & 974831.3125 & 125137.8281 & 271 & 203 & 68 & 61.5 & Bedrock & \\
\hline $1+70$ & 974823.1875 & 125131.9922 & 271 & 202.5 & 68.5 & -- & -- & \\
\hline $1+60$ & 974815.1250 & 125126.1172 & 271 & 200.5 & 70.5 & -- & -- & \\
\hline $1+50$ & 974807.0625 & 125120.2422 & 271 & 200 & 71 & -- & -- & \\
\hline $1+40$ & 974799.0625 & 125114.2031 & 271 & 204.5 & 66.5 & -- & -- & \\
\hline $1+30$ & 974791.1875 & 125108.0703 & 271 & 206 & 65 & -- & -- & \\
\hline $1+20$ & 974783.3750 & 125101.8203 & 271 & 206 & 65 & -- & -- & \\
\hline $1+10$ & 974775.6875 & 125095.4219 & 271 & 202 & 69 & -- & -- & \\
\hline $1+0$ & 974768.1250 & 125088.8672 & 271 & 202 & 69 & -- & -- & \\
\hline
\end{tabular}




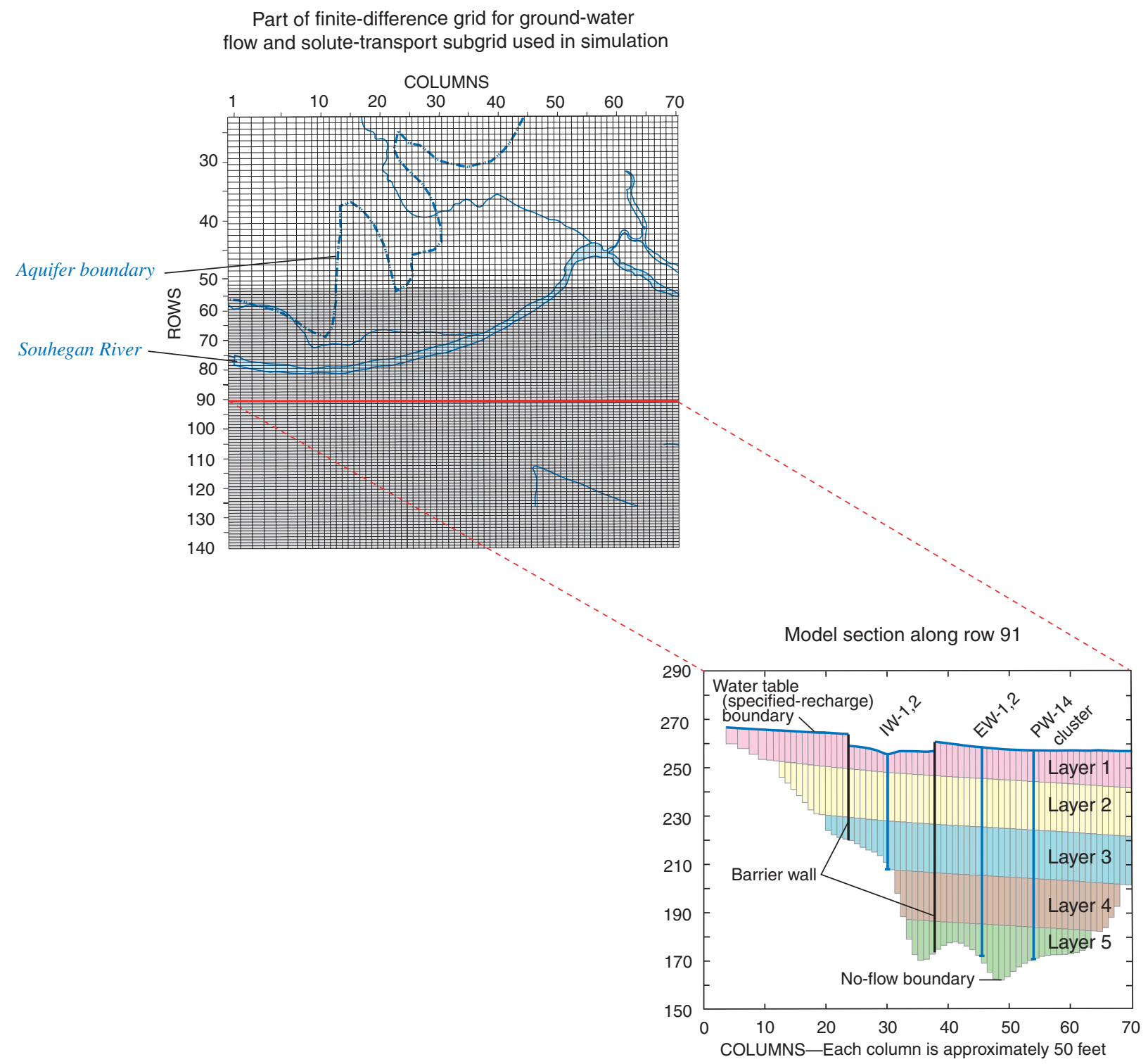

Appendix 4. Vertical discretization for model row 91 of the finite-difference grid, Savage Municipal Supply Well Superfund site, Milford, N.H. Well locations shown on figure 2. 
Prepared by the Publications Service Center 1

For more information concerning the research in this report, contact: Keith W. Robinson, Director

U.S. Geological Survey

New Hampshire-Vermont Water Science Center

361 Commerce Way

Pembroke, NH 03275

or visit our Web site at:

http://nh.water.usgs.gov 
